\title{
Summary of the Radiation Damage Studies of the SDC Dopants in Polystyrene
}

\author{
A. Pla-Dalmau, G.W. Foster and G. Zhang \\ Fermi National Accelerator Laboratory \\ P.O. Box 500, Batavia, Illinois 60510
}

December 1993 


\section{Disclaimer}

This report was prepared as an account of work sponsored by an agency of the United States Government. Neither the United States Government nor any agency thereof, nor any of their employees, makes any warranty, express or implied, or assumes any legal liability or responsibility for the accuracy, completeness, or usefulness of any information, apparatus, product, or process disclosed, or represents that its use would not infringe privately owned rights. Reference herein to any specific commercial product, process, or service by trade name, trademark, manufacturer, or otherwise, does not necessarily constitute or imply its endorsement, recommendation, or favoring by the United States Government or any agency thereof. The views and opinions of authors expressed herein do not necessarily state or reflect those of the United States Government or any agency thereof. 


\section{Summary of the Radiation Damage Studies of the SDC Dopants in Polystyrene}

A. Pla-Dalmau, G. W. Foster, and G. Zhang

Fermi National Accelerator Laboratory

P. O. Box 500, Batavia, IL 60510, USA

December 22, 1993 
TABLE OF CONTENTS

PAGE

Introduction

iv

Radaition Damage Set \#20

$\mathrm{K} 27$

C35/C481

4

C153

6

C314T

C338

C478

C480

12

C485

14

$\mathrm{C} 487$

16

C490

18

C498

20

C500

22

C503

24

C504

26

C510

28

C515

30

C519

32

C521

34

C522

36

C523

38

C525

40

C535

42

C540

44

C545

46

LPY

Radiation Damage Set \#22

Acridine O B

53

Acridine $Y$

54

Acriflavin

55

BBOT

56

bis-MSB

57

BSFL

58

Carbostyril3

59

Carbostyril124

60

DCM/DCM2

61

DIACFN

63

DIBRFN

64

DICLFN/FN548

65 
$\begin{array}{ll}\text { DMETCI } & 66\end{array}$

$\begin{array}{ll}\text { DMPOPOP } & 67\end{array}$

$\begin{array}{ll}\mathrm{DOCl} & 68\end{array}$

DODCl $\quad 69$

DODCl+C-E $\quad 70$

DQOCI $\quad 71$

$\begin{array}{ll}\mathrm{DTCl} & 72\end{array}$

DTDCI $\quad 73$

$\begin{array}{ll}\mathrm{HIDCl} & 74\end{array}$

$\begin{array}{ll}\text { ISCNFN } & 75\end{array}$

Kiton Red $\quad 76$

LD $490 \quad 77$

LD $688 \quad 78$

LDS $722 \quad 79$

LDS $730 \quad 80$

LDS $750 \quad 81$

Malachite Green $\quad 82$

Nile Blue $\quad 83$

Oxazine $725 \quad 84$

$\begin{array}{lr}\text { Pyridine } 1 & 85\end{array}$

$\begin{array}{ll}\text { Rhodamine 6G } & 86\end{array}$

$\begin{array}{ll}\text { Rhodamine } 575 & 87\end{array}$

$\begin{array}{ll}\text { Stilbene } 420 & 88\end{array}$

Appendix A: List of Dopant Structures $\quad 89$

Appendix B: List of Dopant Names $\quad 99$ 


\section{Introduction}

Approximately 80 commercially available fluorescent organic compounds were studied as dopants in a polystyrene matrix for possible use in wavelength shifting (WLS) fibers. The goal was to find a new green-emitting WLS fiber which would outperform in light yield and decay time the currently available fiber doped with K-27. Therefore the fluorescent compounds of interest should exhibit the following spectroscopic characteristics in polystyrene: $\lambda_{a b s}=400-450 \mathrm{~nm}, \lambda_{e m}=450-550 \mathrm{~nm}, \tau=3-7 \mathrm{~ns}(\tau=12 \mathrm{~ns}$ for K-27), and quantum efficiency of minimum 0.7 (K-27 baseline). For further details on the range and properties of the compounds studied refer to "Final Results from the SDC Dopant Search for New Green Wavelength Shifting (WLS) Fibers", FERMILAB-TM-1873.

Polystyrene samples doped with different fluorescent compounds were prepared and characterized. Of all the compounds tested, only a series of coumarins exhibited the spectroscopic characteristics of interest. Radiation damage studies had to be performed on these samples in order to conclusively determine if they were better candidates than K-27 for green WLS fibers.

All samples except those showing opacity or deep coloration were irradiated. They were, however, separated in two sets. Radiation damage set No. 20 (RD20) was mainly formed by the coumarin derivatives. Radiation damage set No. 22 (RD22) was based on the remaining samples. The irradiations were performed at the Phoenix Memorial Laboratory (University of Michigan) using a ${ }^{60} \mathrm{Co}$ source. Both sets were exposed to a total dose of $10 \mathrm{Mrad}$ in air, at a dose rate of $1.8 \mathrm{Mrad} / \mathrm{h}$. Transmittance measurements were recorded before and after irradiation, and after annealing. After irradiation, the samples were annealed in oxygen to accelerate the recovery process. Although the samples were irradiated in air, they still underwent annealing in oxygen atmosphere because the dose rate had been high enough for the oxygen diffusion rate to be smaller than its consumption rate during irradiation. The final results are similar to those of an irradiation under inert atmosphere, with the exception of the formation of oxidation products on the surface of the samples.

Transmittance spectra were recorded with a Hewlett-Packard model 8451A diode array spectrophotometer. All transmittance measurements used undoped and unirradiated polystyrene as the reference. The transmittance 
plots presented here observe the formal separation of the two sets, RD20 and RD22. The data for RD20 has been arranged in two plots for each dopant. The first plot shows the transmittance spectra before irradiation and after annealing. The second plot includes the transmittance spectra before irradiation plus two transmittance spectra recorded while the sample was annealing. For RD22, the data is shown in one single plot containing three measurements: one before irradiation, one after irradiation, and one after annealing in oxygen.

The RD20 data indicates that the performance under irradiation of the coumarins is significantly inferior to that of K-27. The losses in transmission of the coumarins are larger than those of K-27.

We wish to thank R. Blackburn of the Phoenix Memorial Laboratory of the University of Michigan for performing all sample irradiations. We wish to extend our appreciation to the members of the Particle Detector Group; in particular, Monica Szelag who plotted and organized the data presented in this document. 
PART I

RADIATION DAMAGE SET \#20 
0.02\% K27 - HIGH DOSE RATE IRRADIATION IN AIR

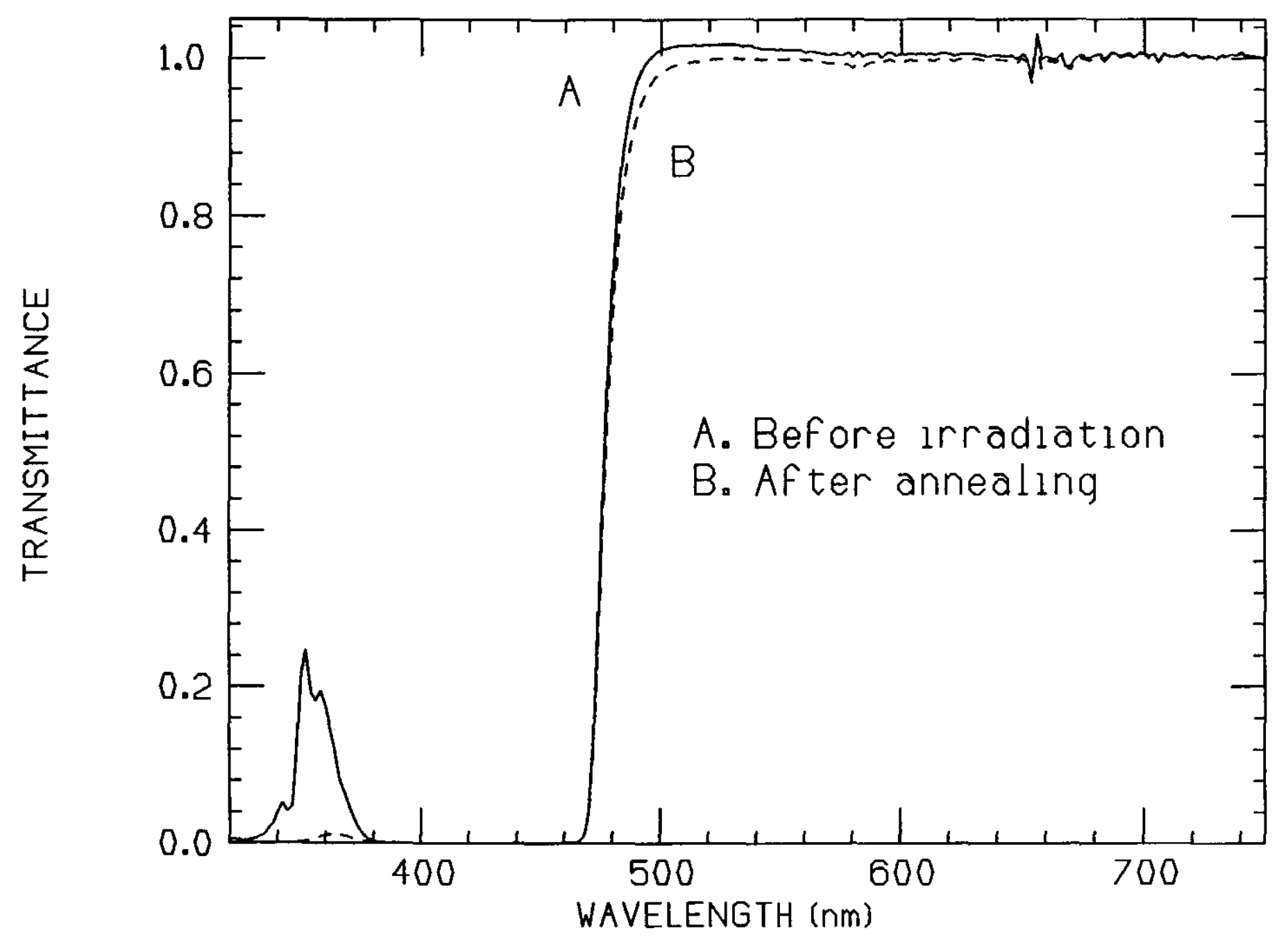


$0.02 \%$ K27 - HIGH DOSE RATE IRRADIATION IN AIR

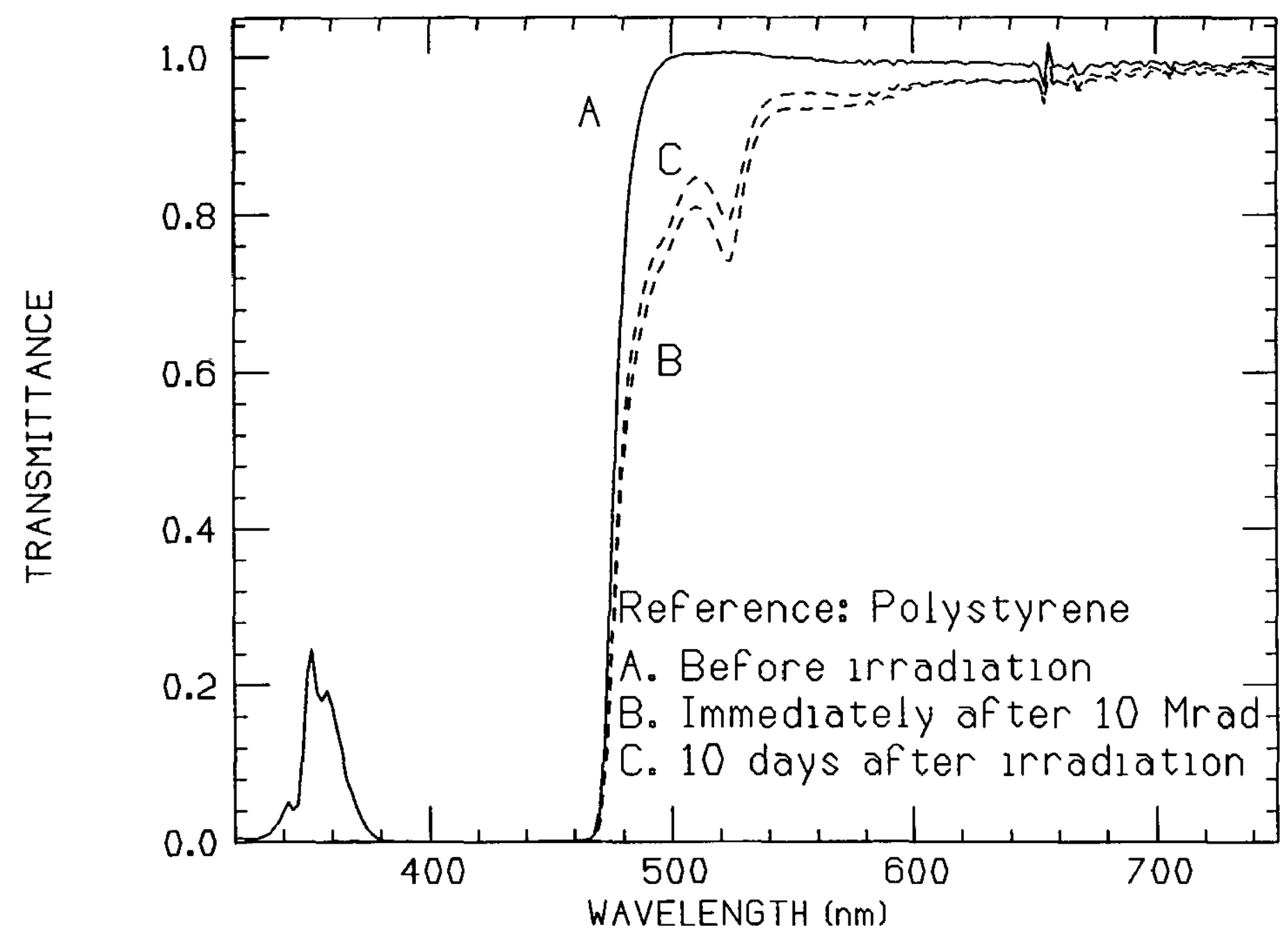




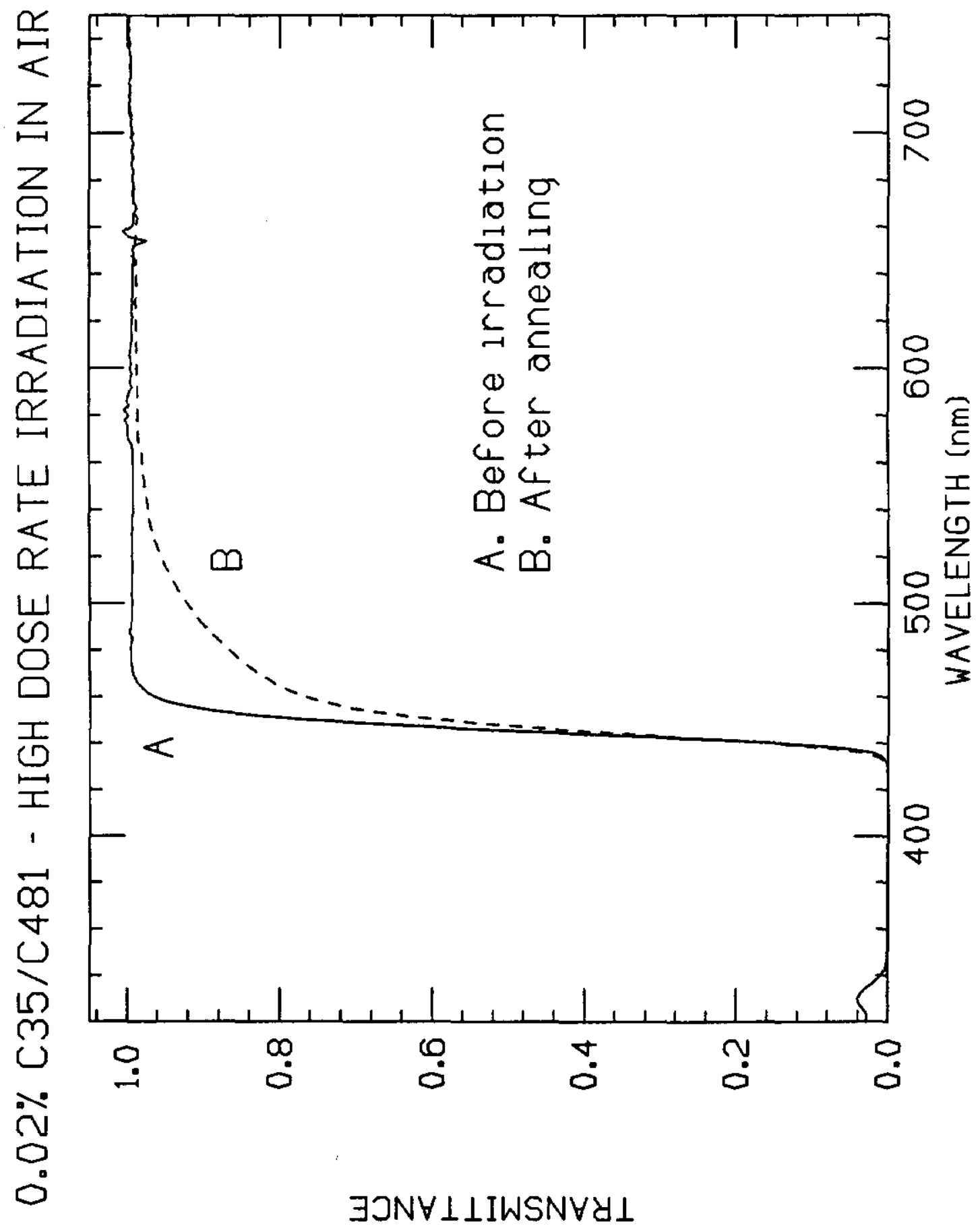


0.02\% C35/C 481 - HIGH DOSE RATE IRRADIATION IN AIR

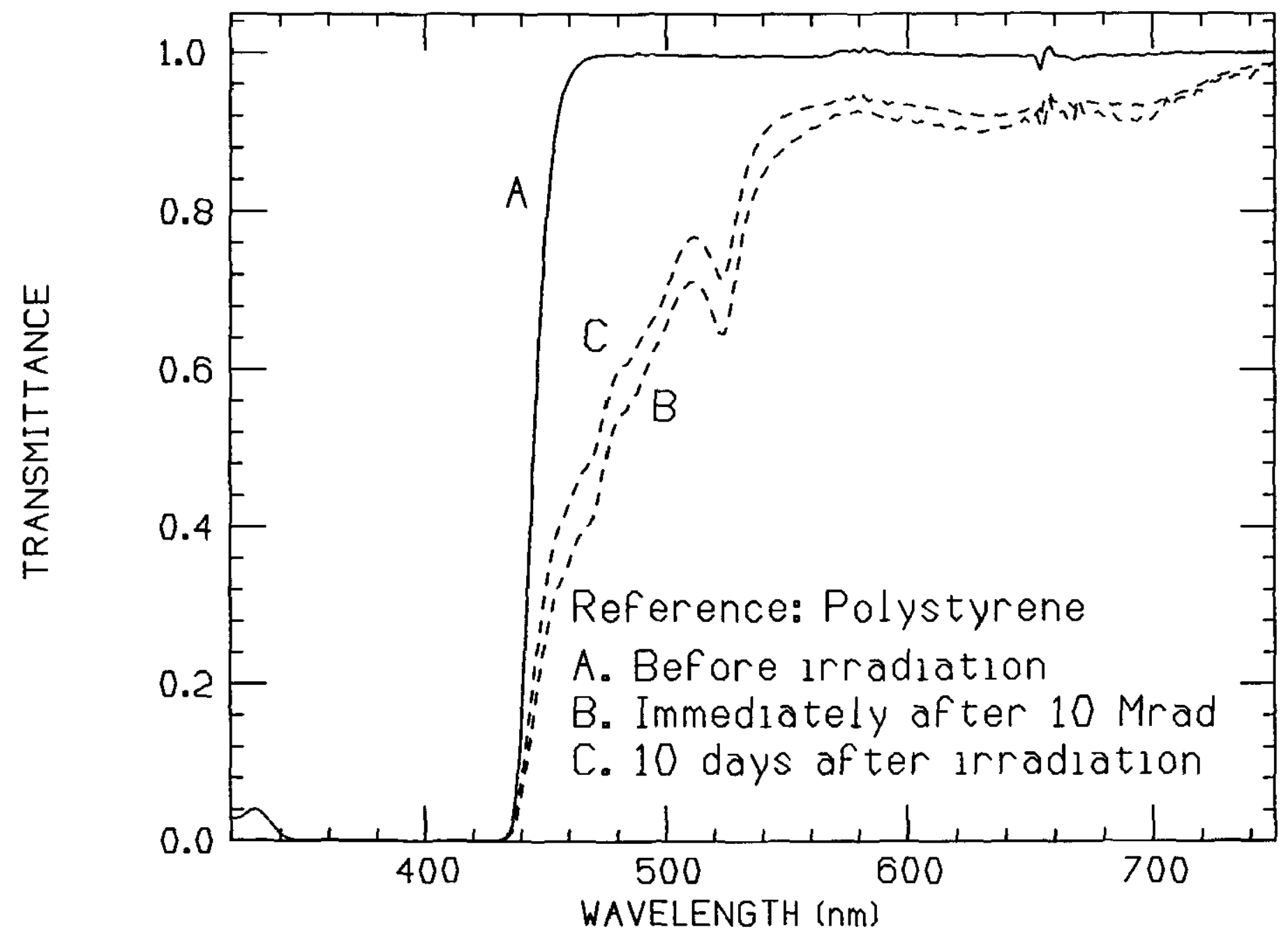


0.02\% C153 - HIGH DOSE RATE IRRADIATION IN AIR

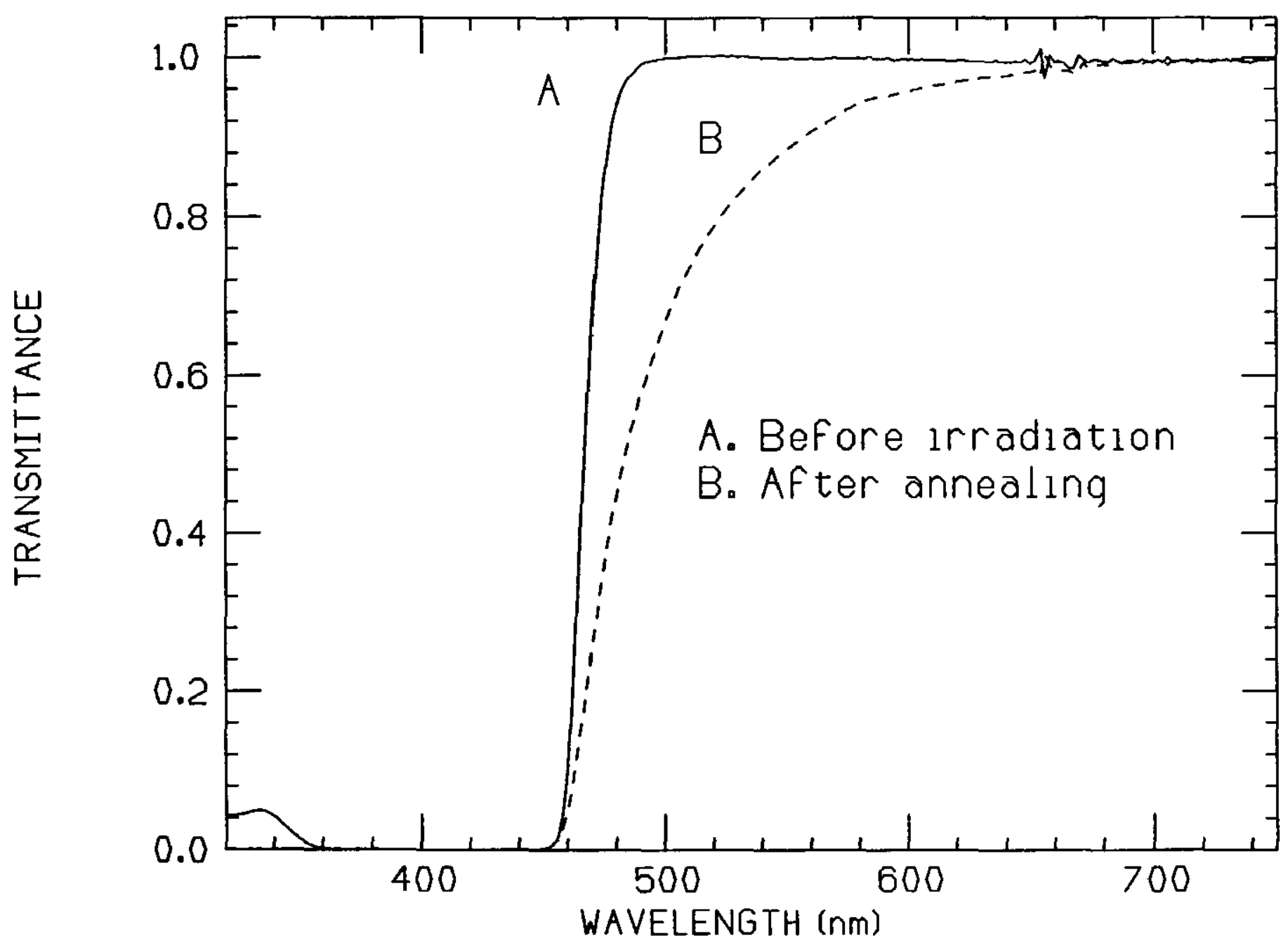


0.02\% C153 - HIGH DOSE RATE IRRADIATION IN AIR

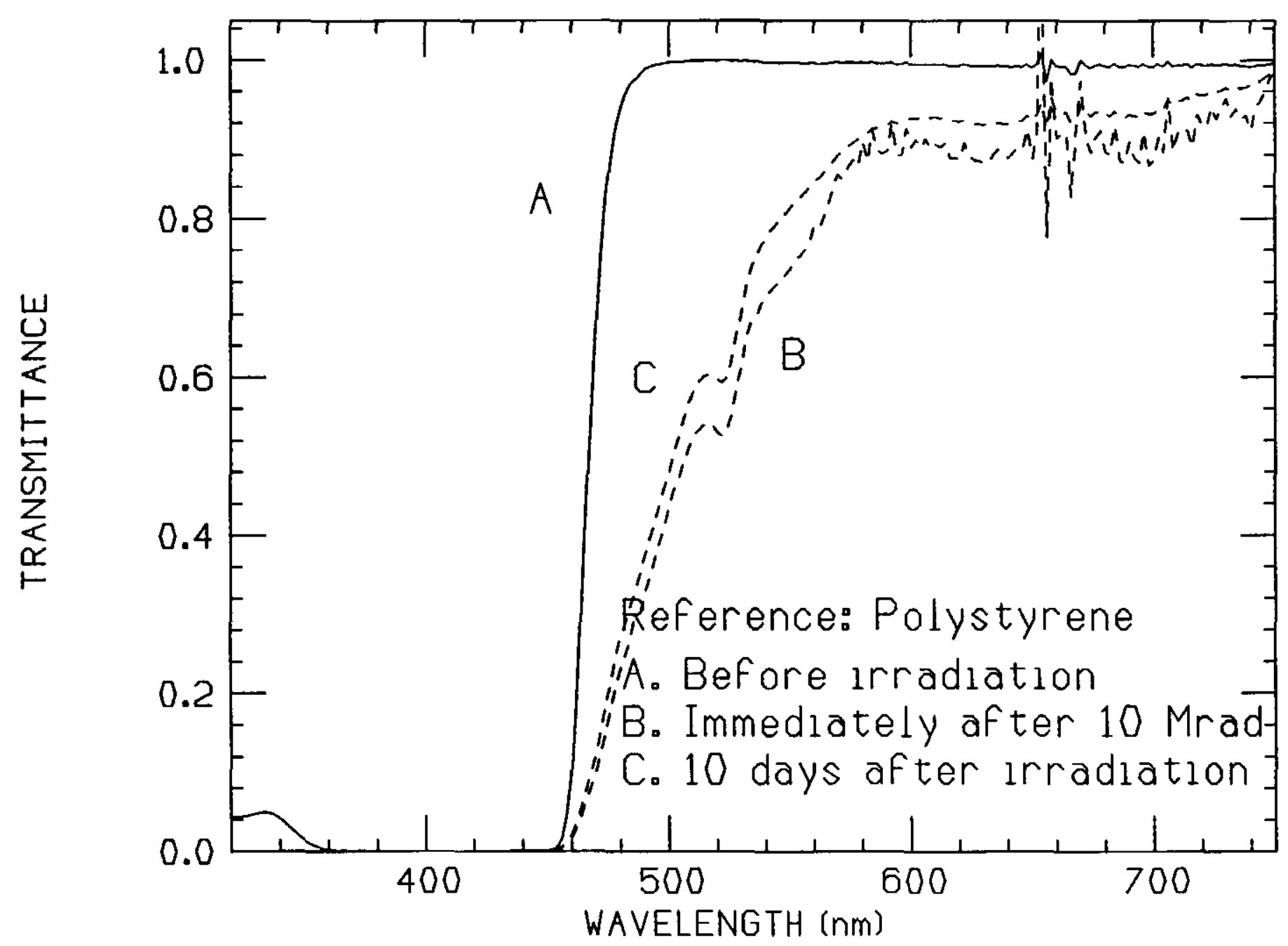


$0.02 \%$ C $314 T$ - HIGH DOSE RATE IRRADIATION IN AIR

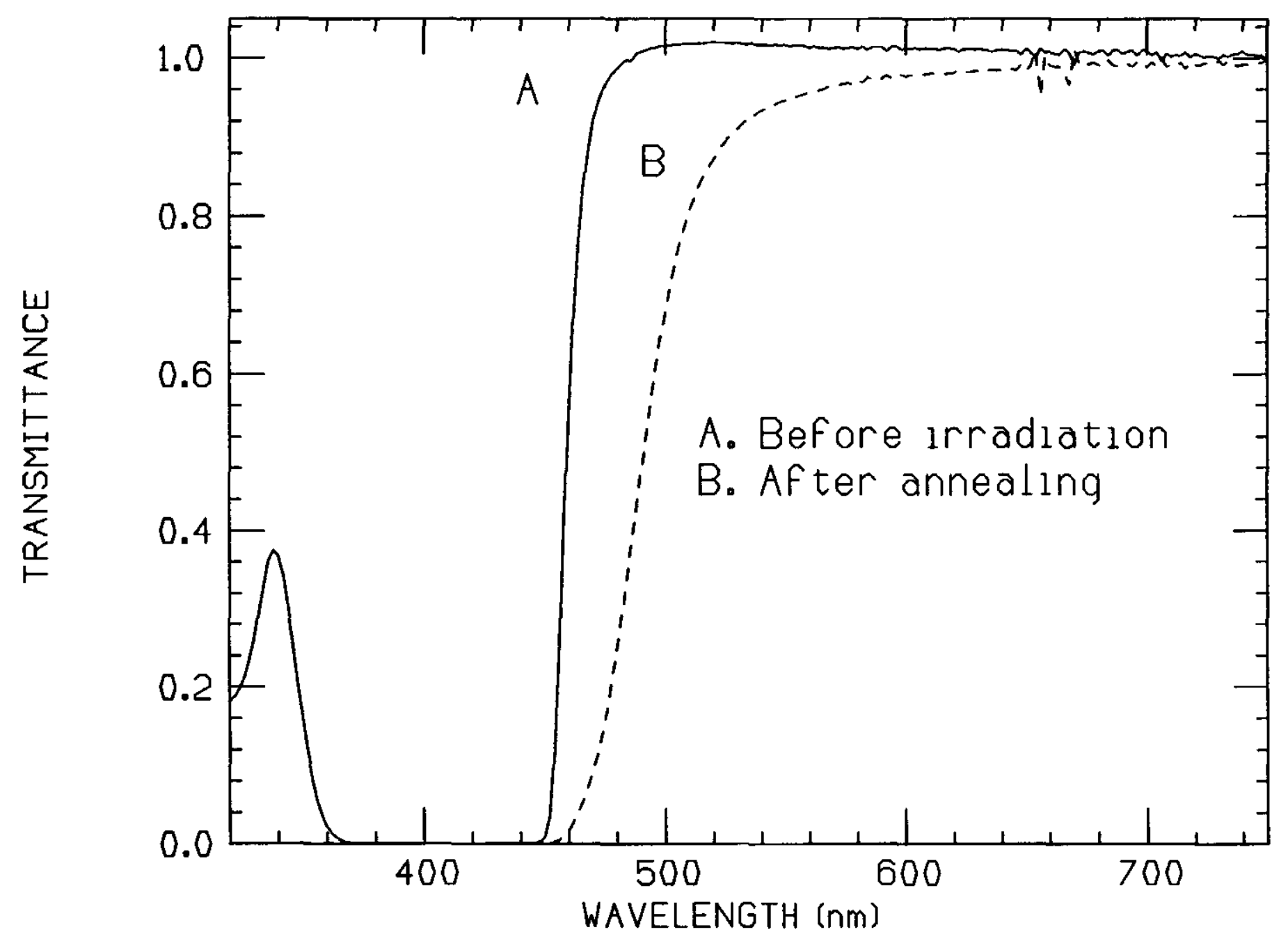


0.02\% C314T - HIGH DOSE RATE IRRADIATION IN AIR

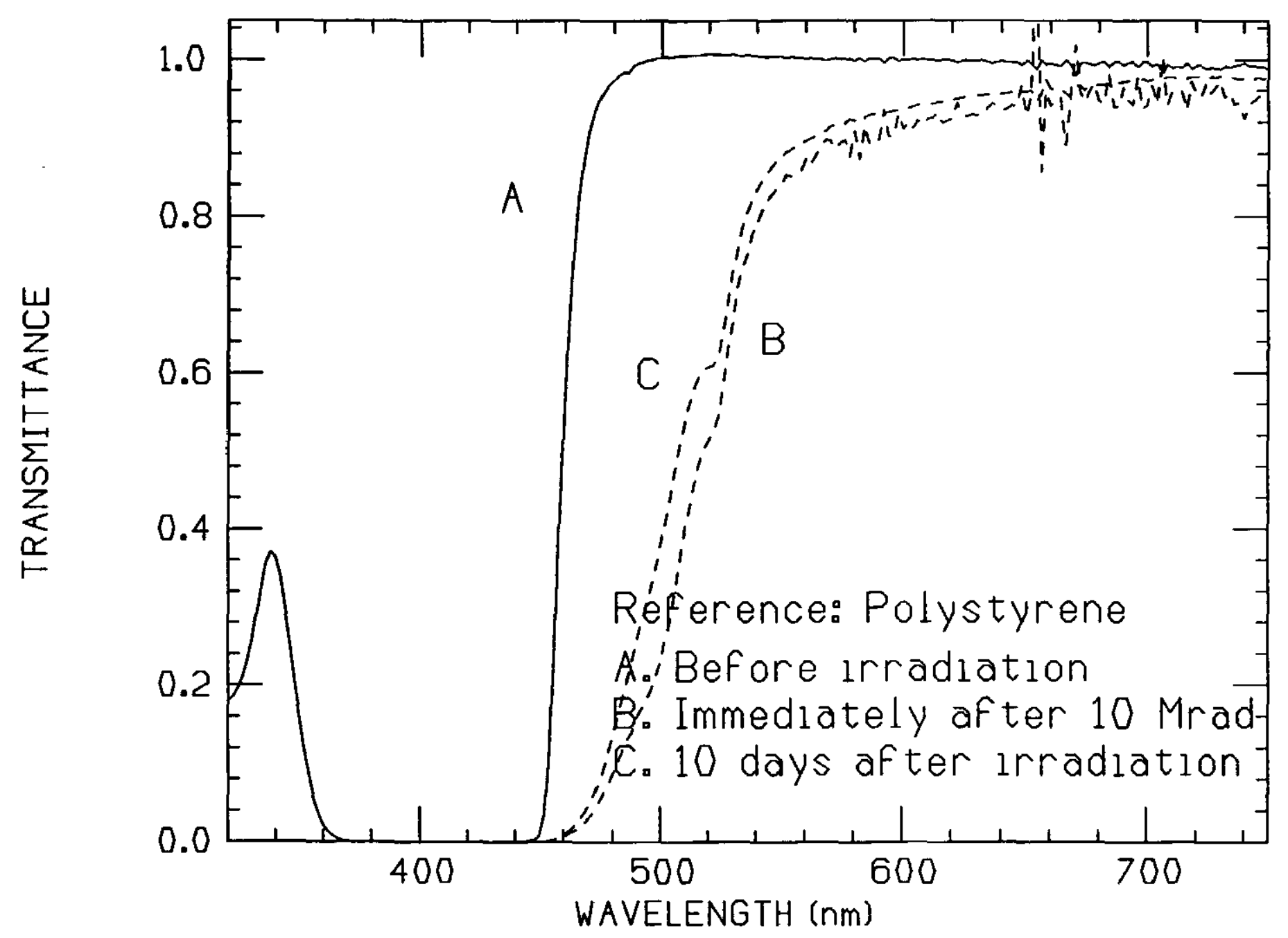


0.02\% C338 - HIGH DOSE RATE IRRADIATION IN AIR

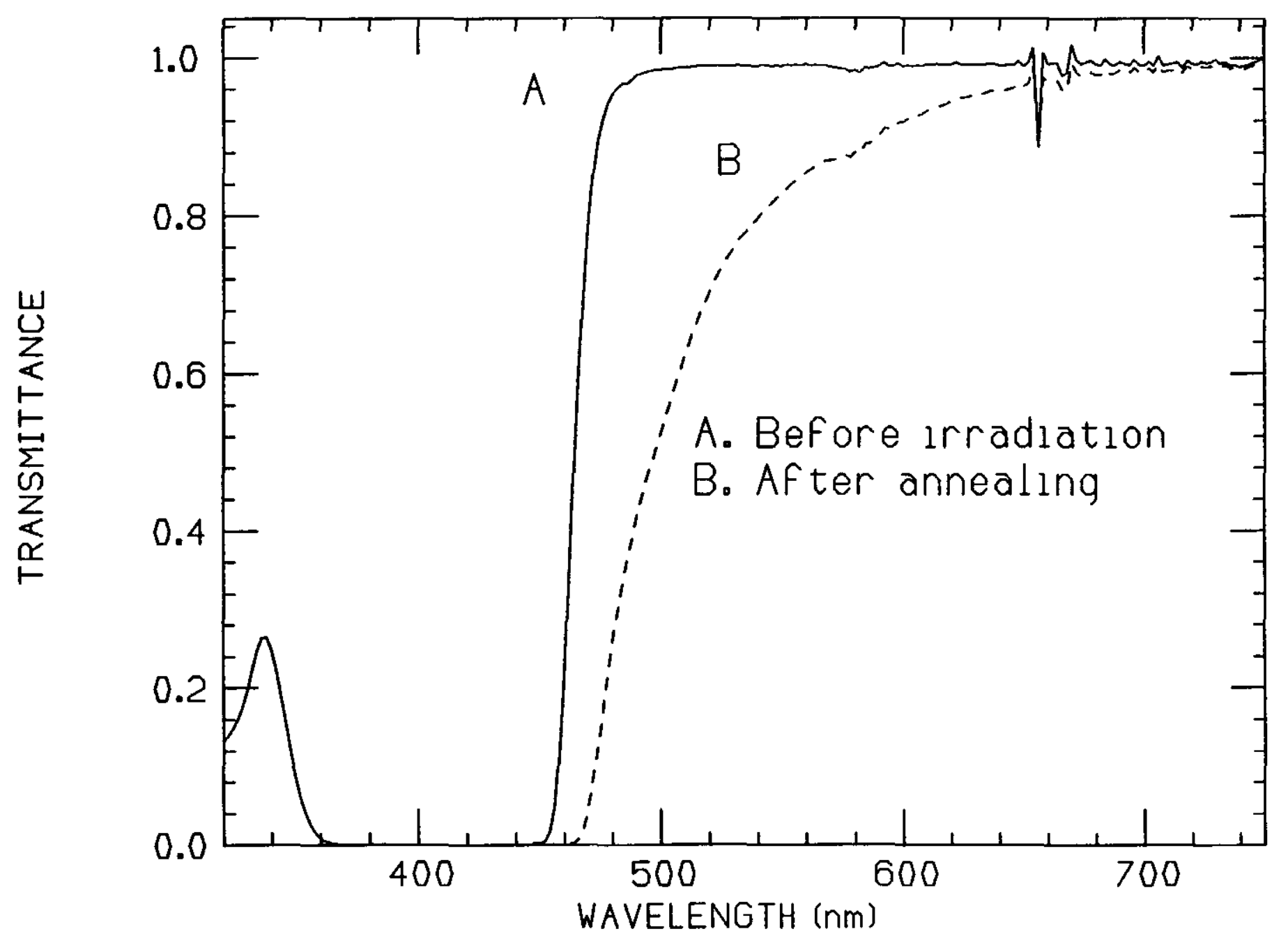


0.02\% C338 - HIGH DOSE RATE IRRADIATION IN AIR

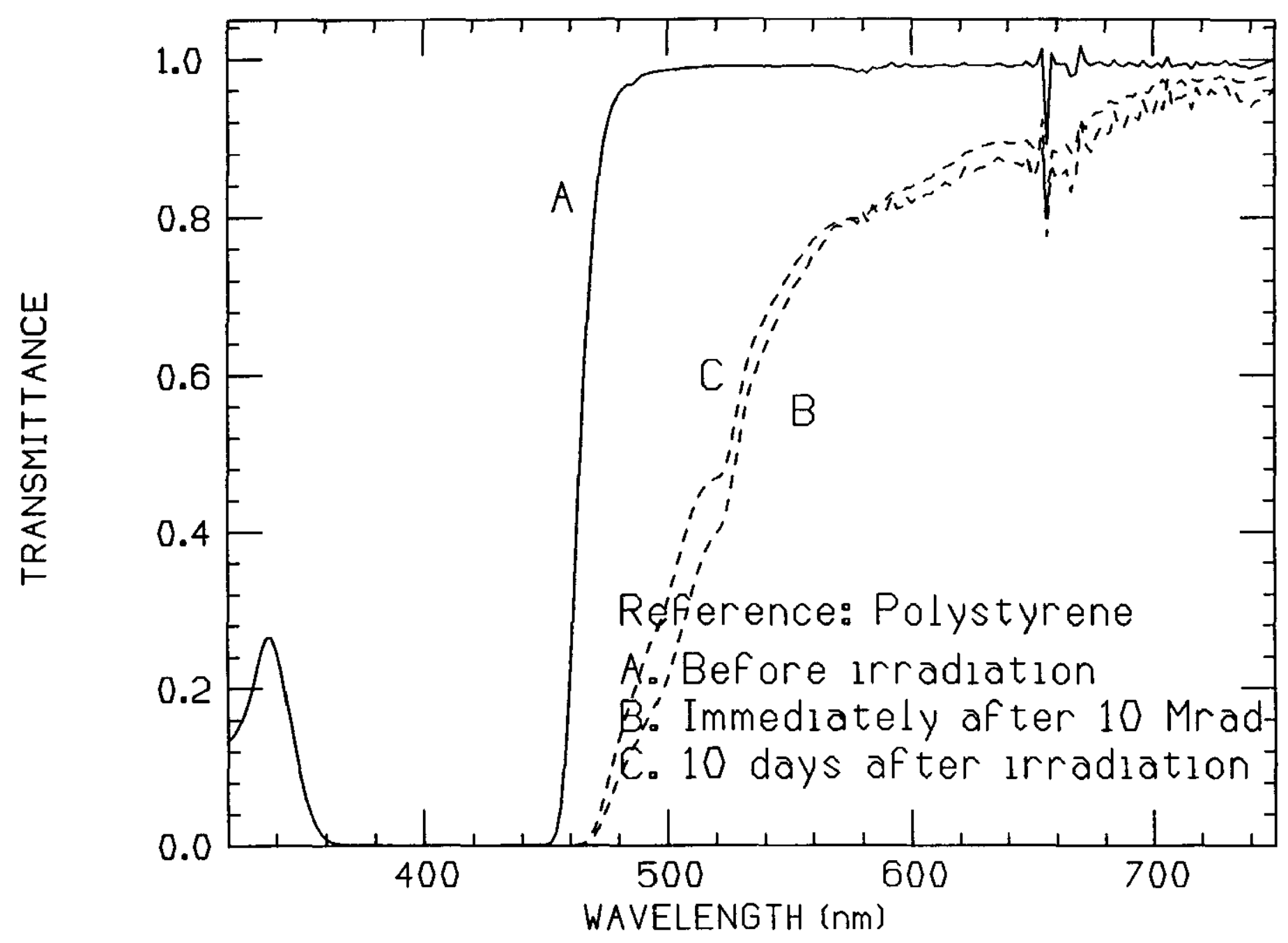




\subsection{2\% C478 - HIGH DOSE RATE IRRADIATION IN AIR}

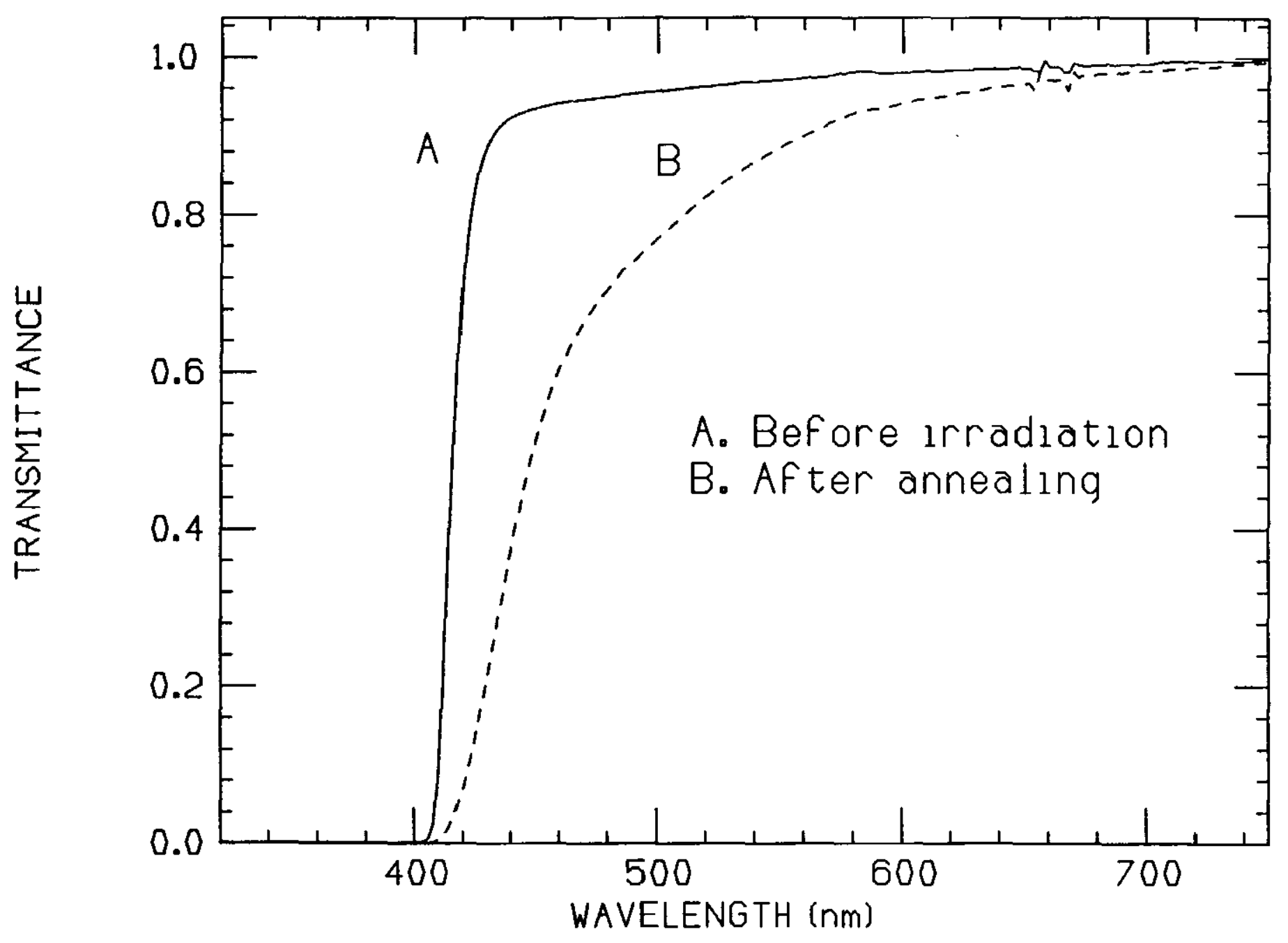


0.02\% C478 - HIGH DOSE RATE IRRADIATION IN AIR

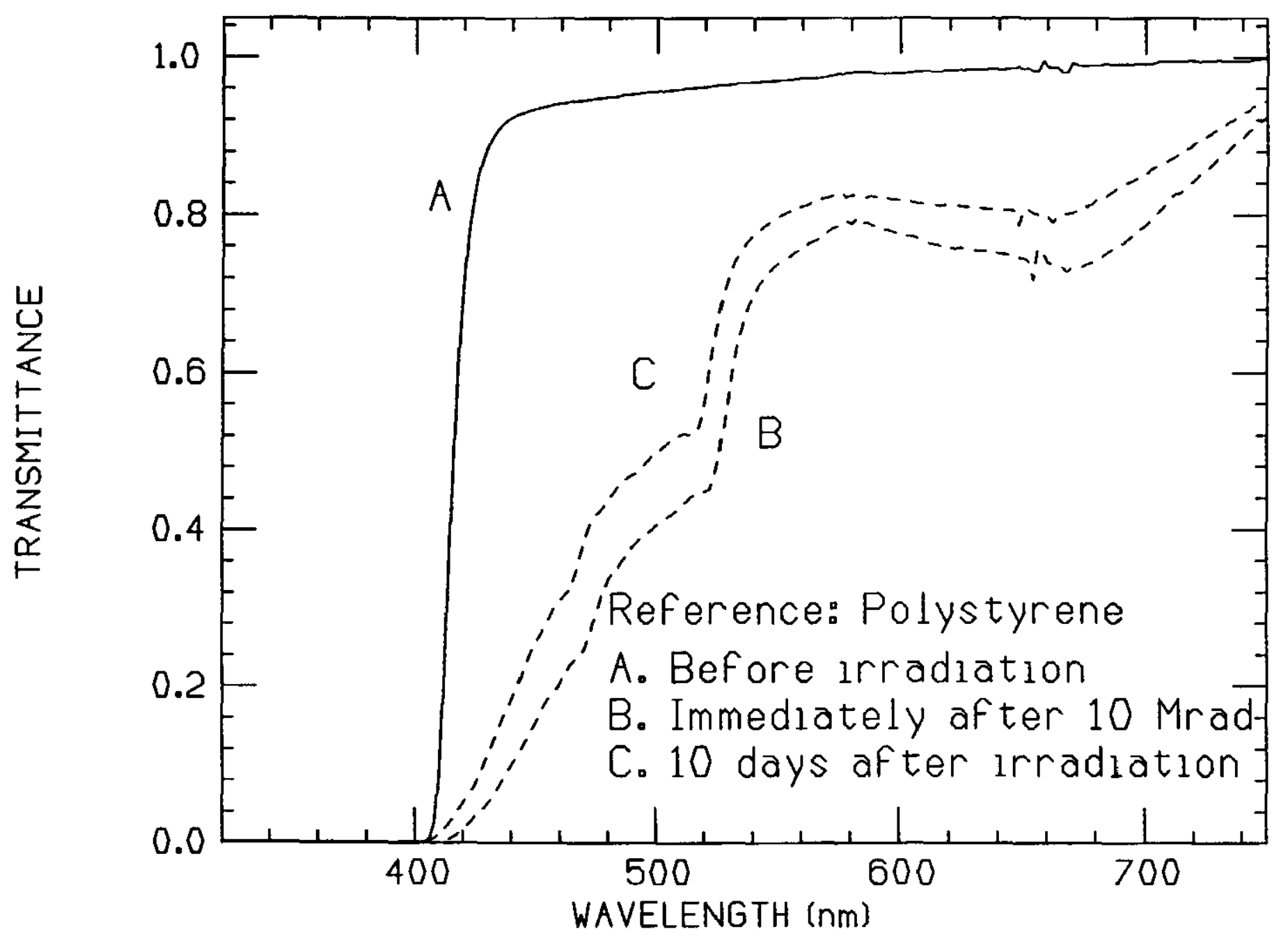


0.02\% C480 - HIGH DOSE RATE IRRADIATION IN AIR

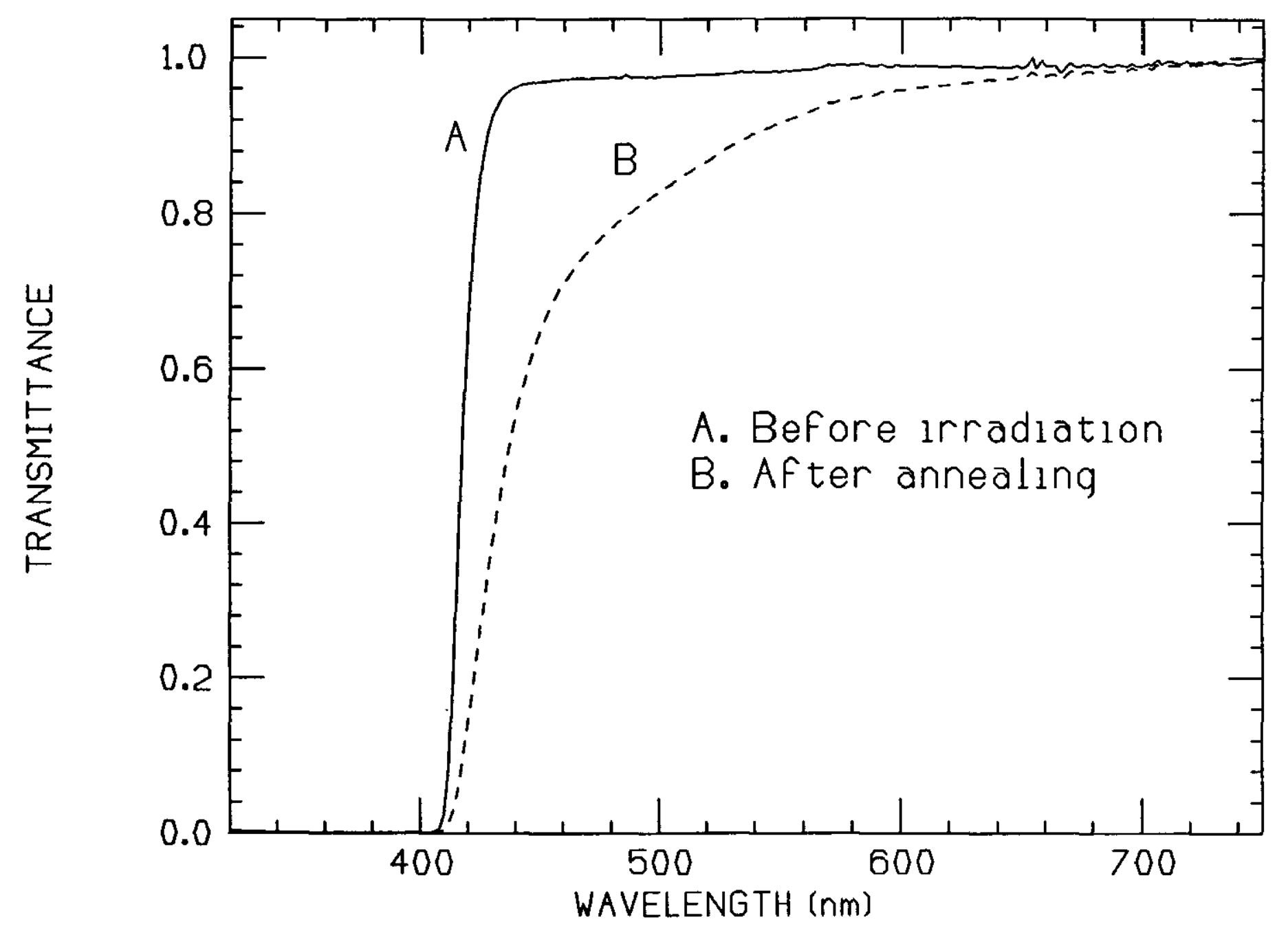




\subsection{2\% C480 - HIGH DOSE RATE IRRADIATION IN AIR}

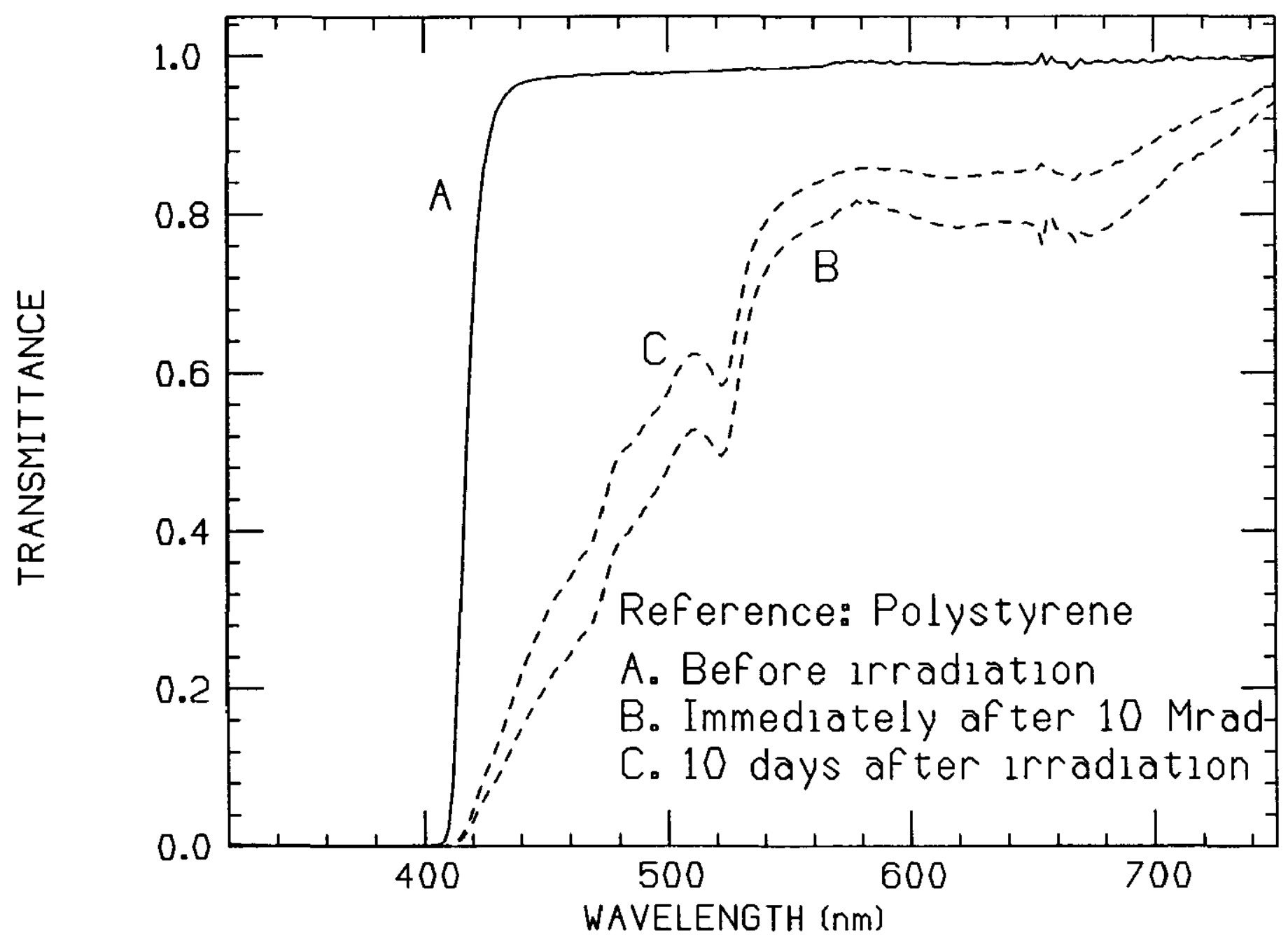


0.02\% C485 - HIGH DOSE RATE IRRADIATION IN AIR

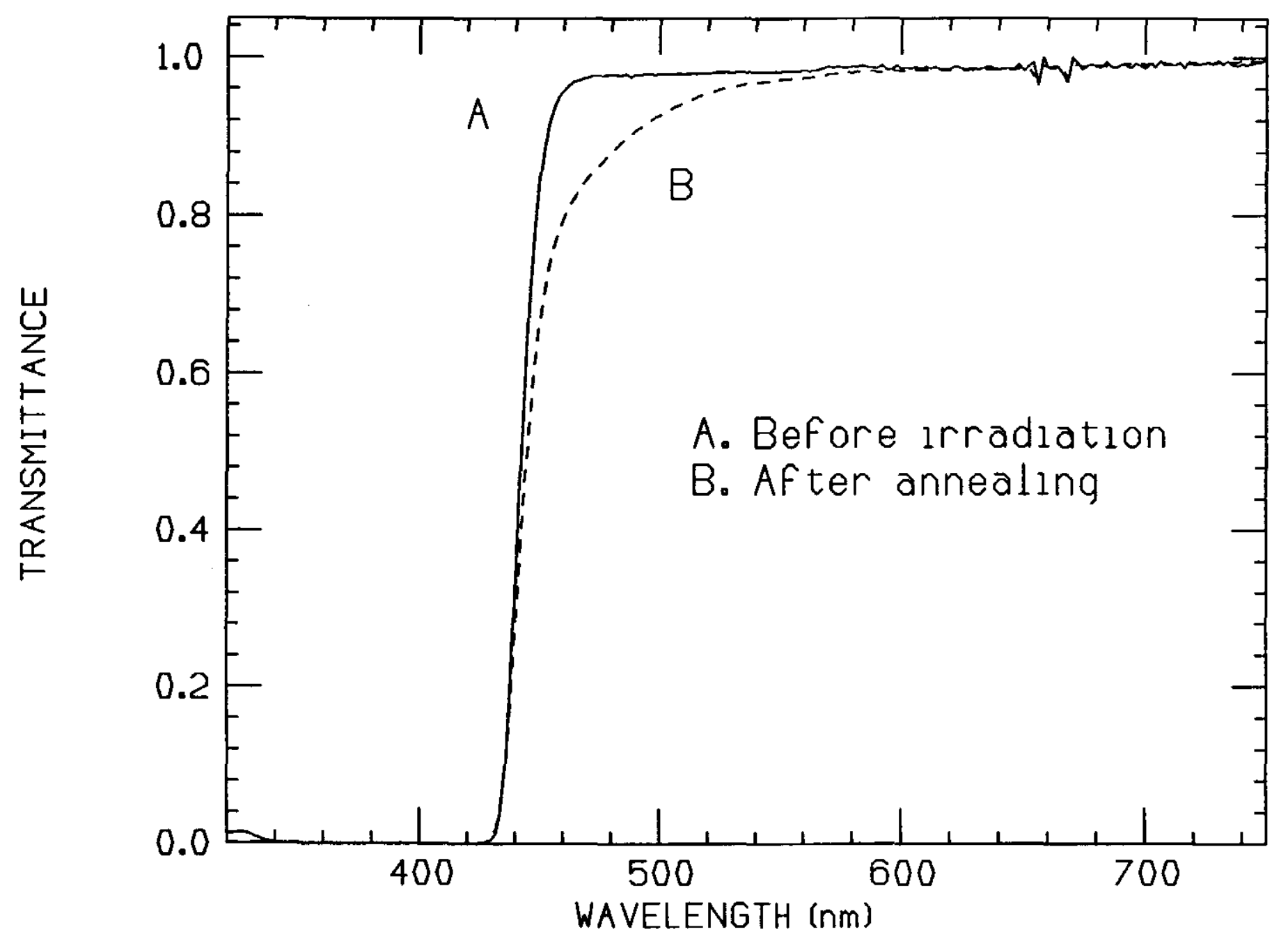


0.02\% C485 - HIGH DOSE RATE IRRADIATION IN AIR

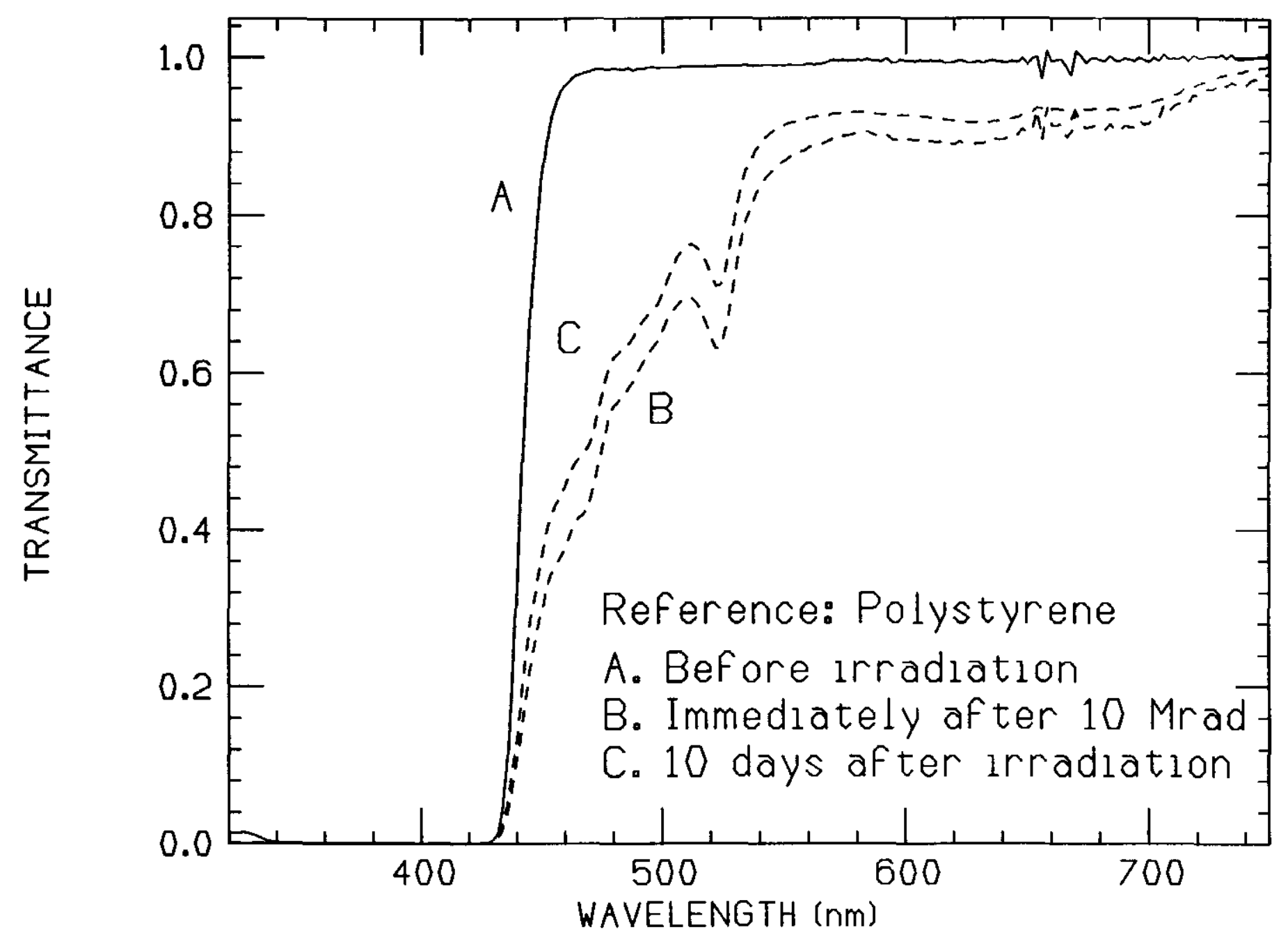


0.02\% C487 - HIGH DOSE RATE IRRADIATION IN AIR

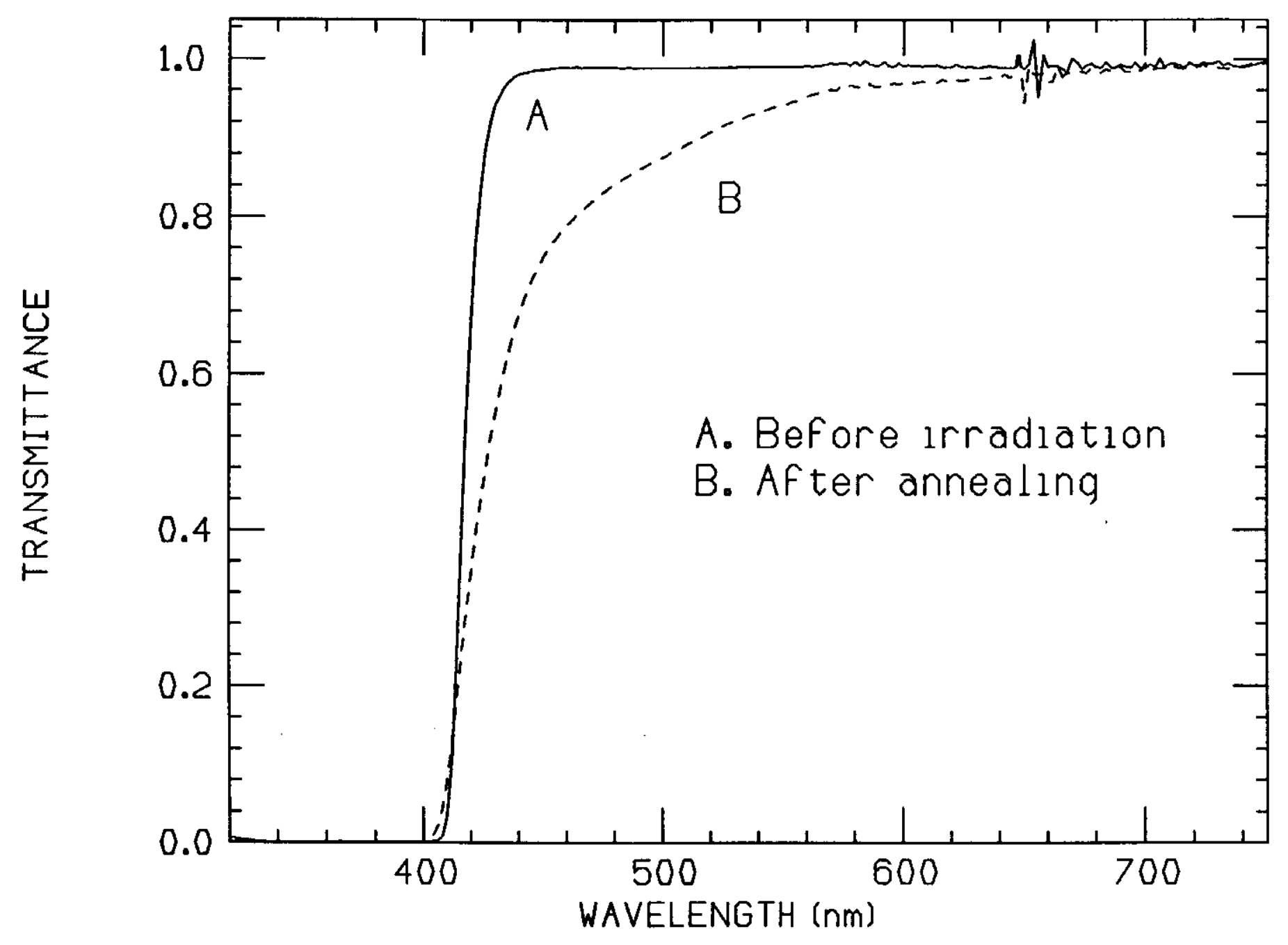




\subsection{2\% C487 - HIGH DOSE RATE IRRADIATION IN AIR}

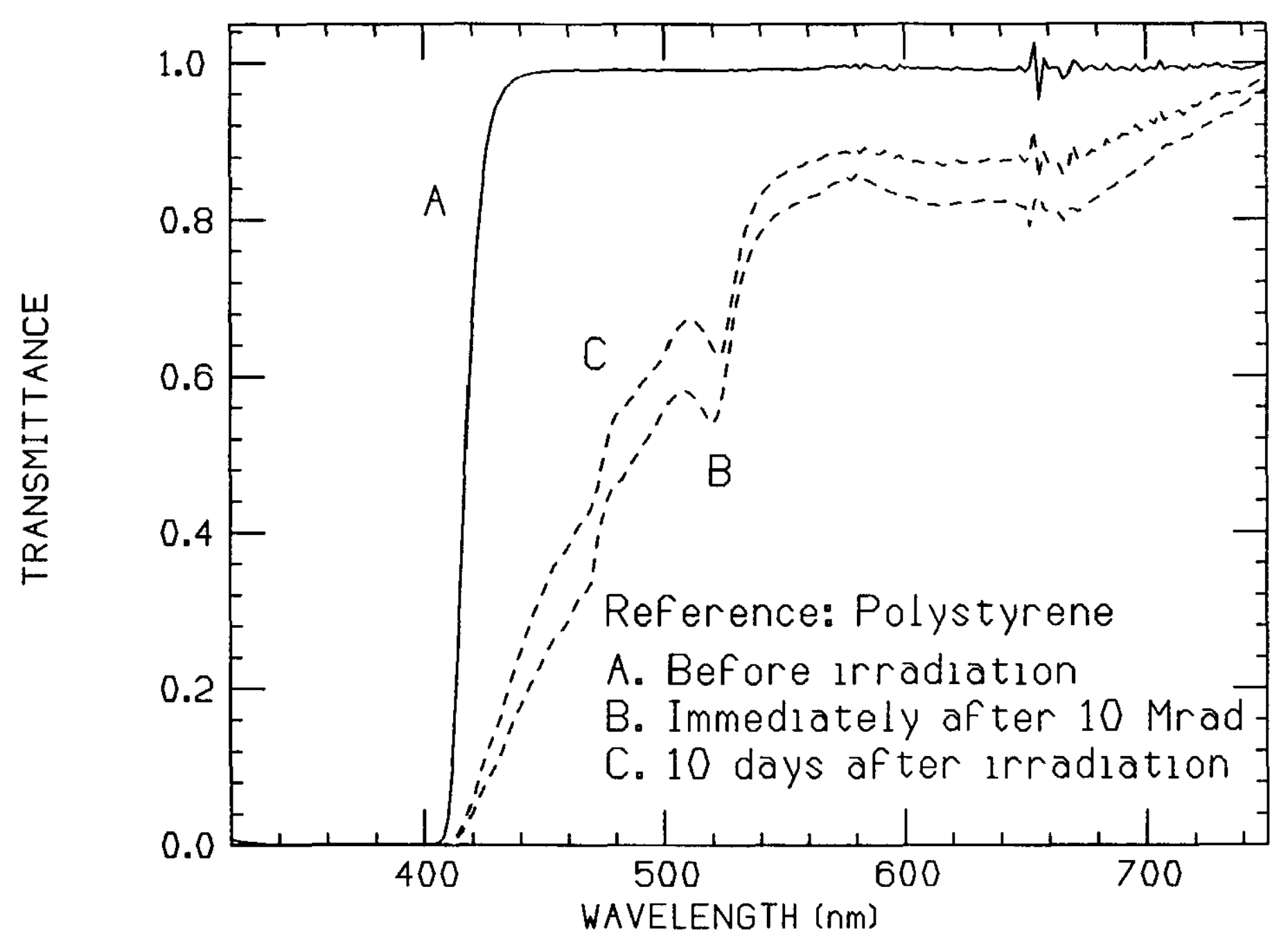




\section{$0.02 \%$ C 490 - HIGH DOSE RATE IRRADIATION IN AIR}

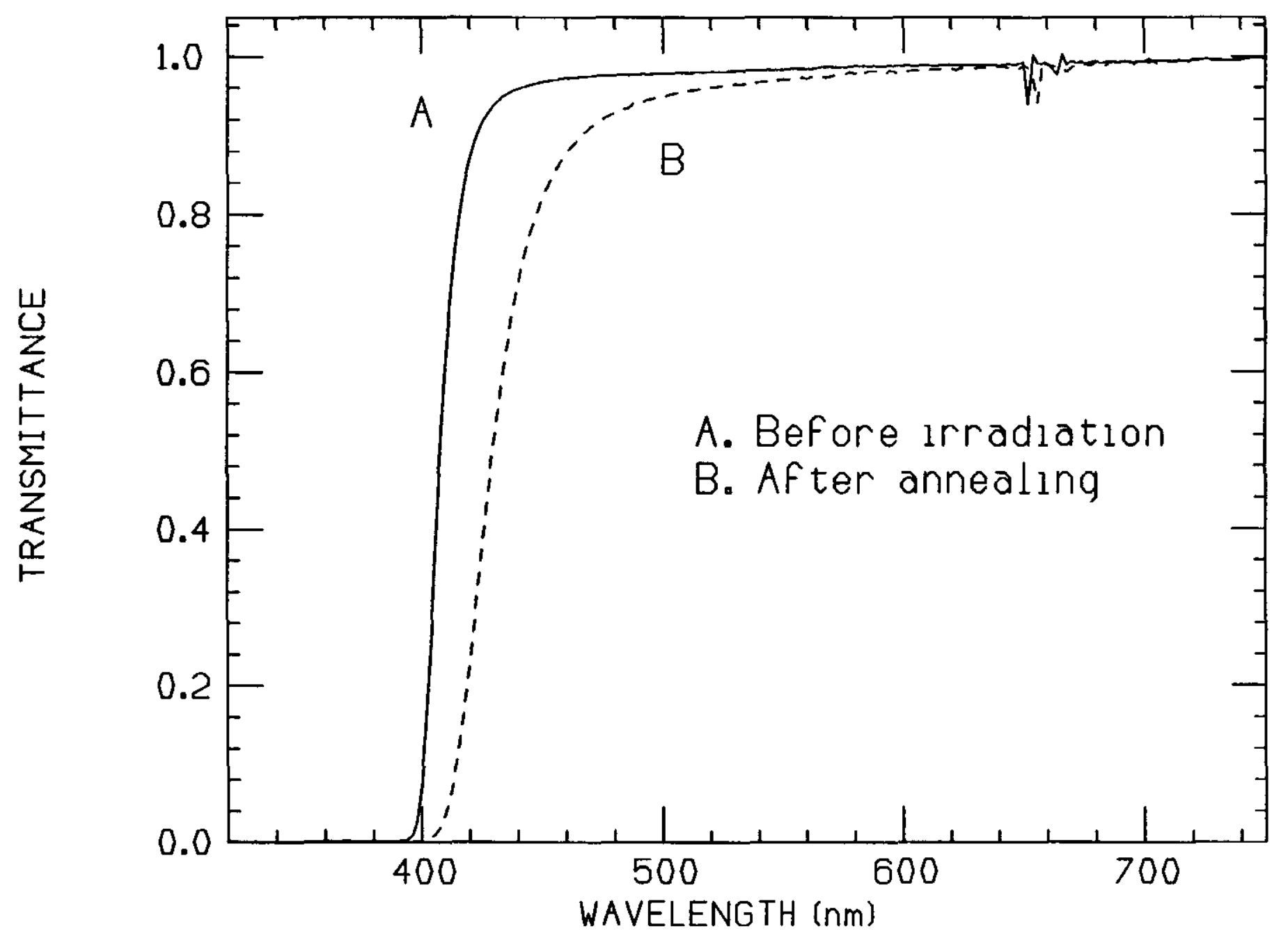




\subsection{2\% C490 - HIGH DOSE RATE IRRADIATION IN AIR}

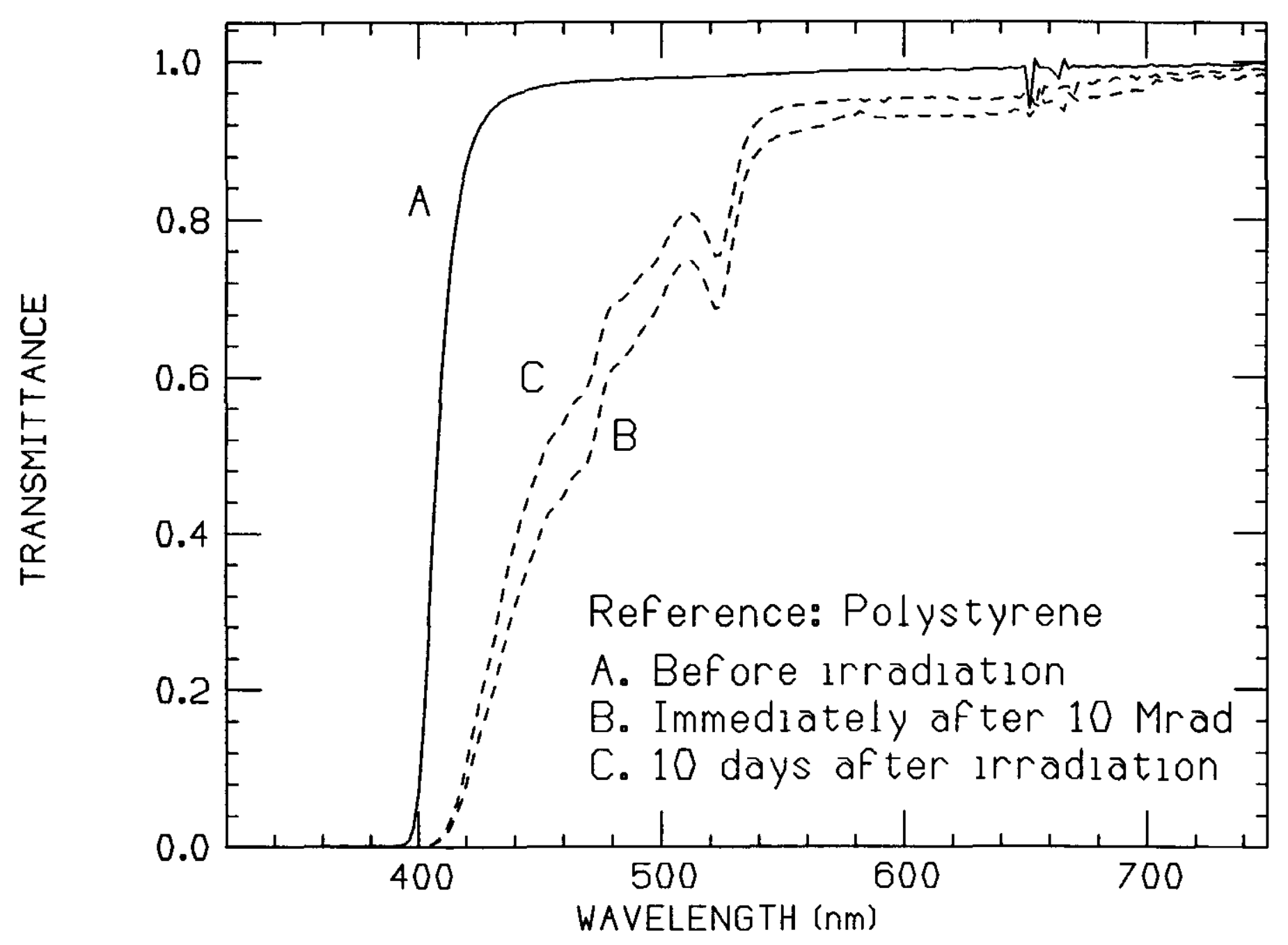


0.02\% C498 - HIGH DOSE RATE IRRADIATION IN AIR

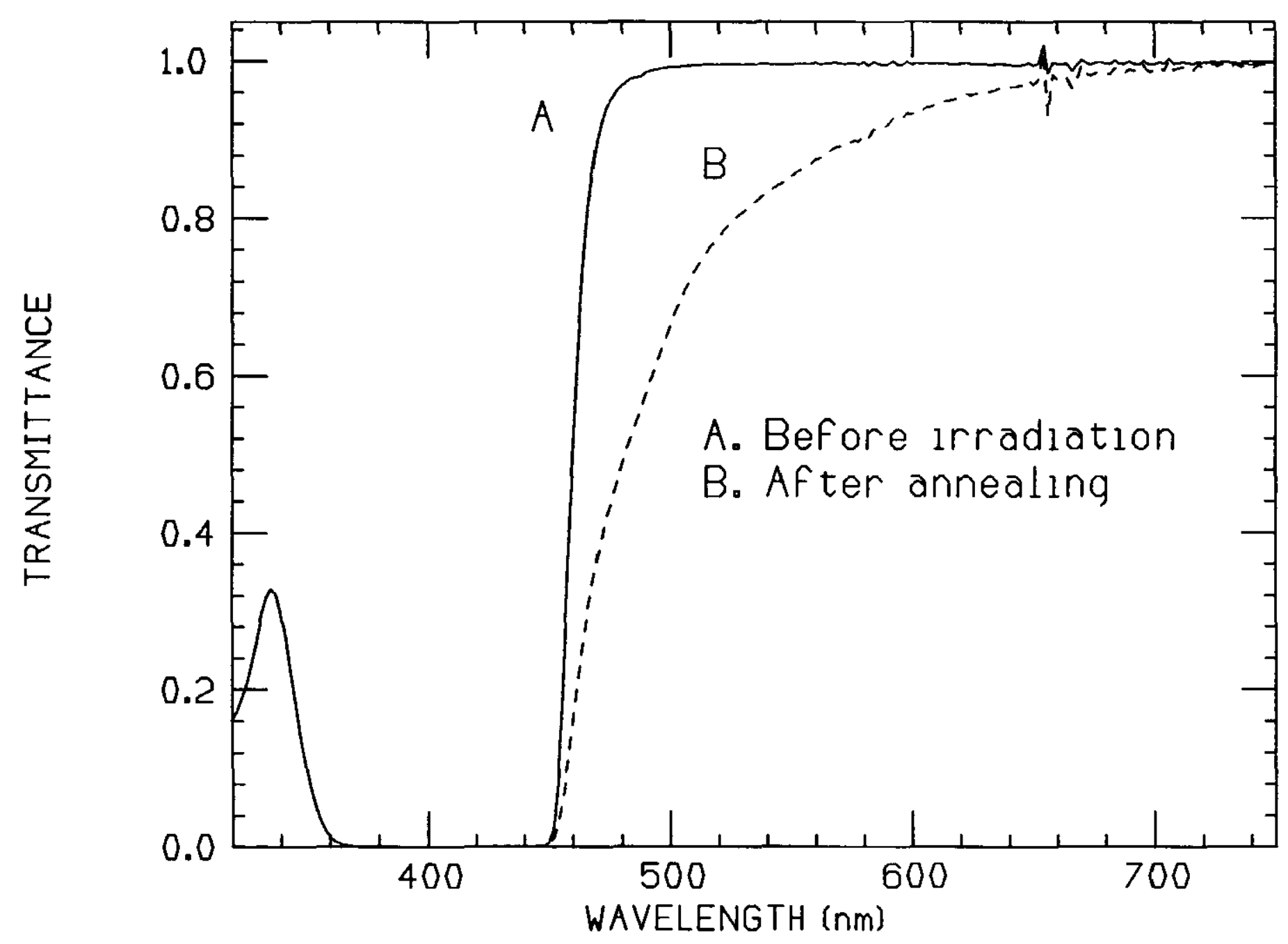




\subsection{2\% C498 - HIGH DOSE RATE IRRADIATION IN AIR}

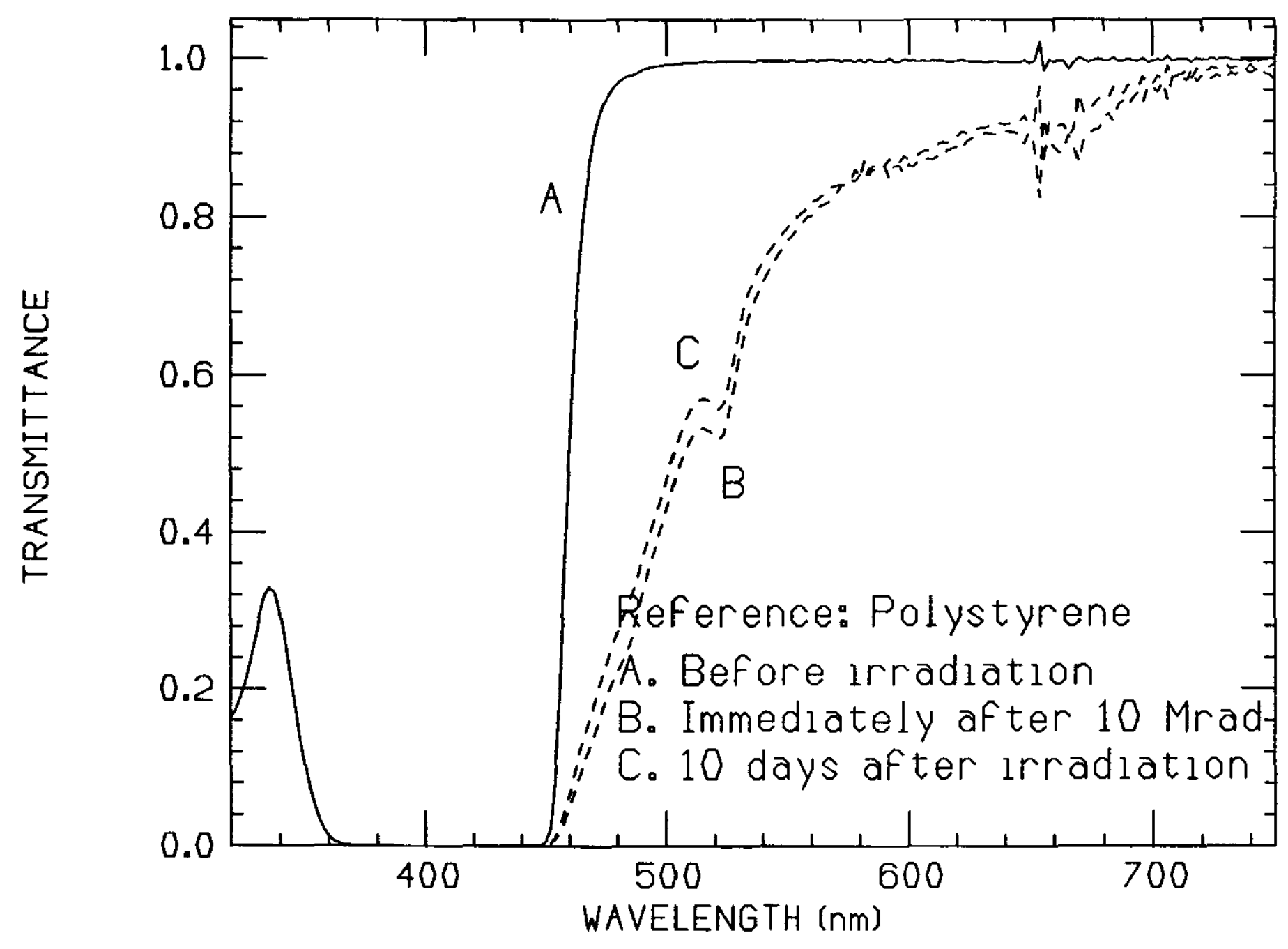


0.02\% C500 - HIGH DOSE RATE IRRADIATION IN AIR

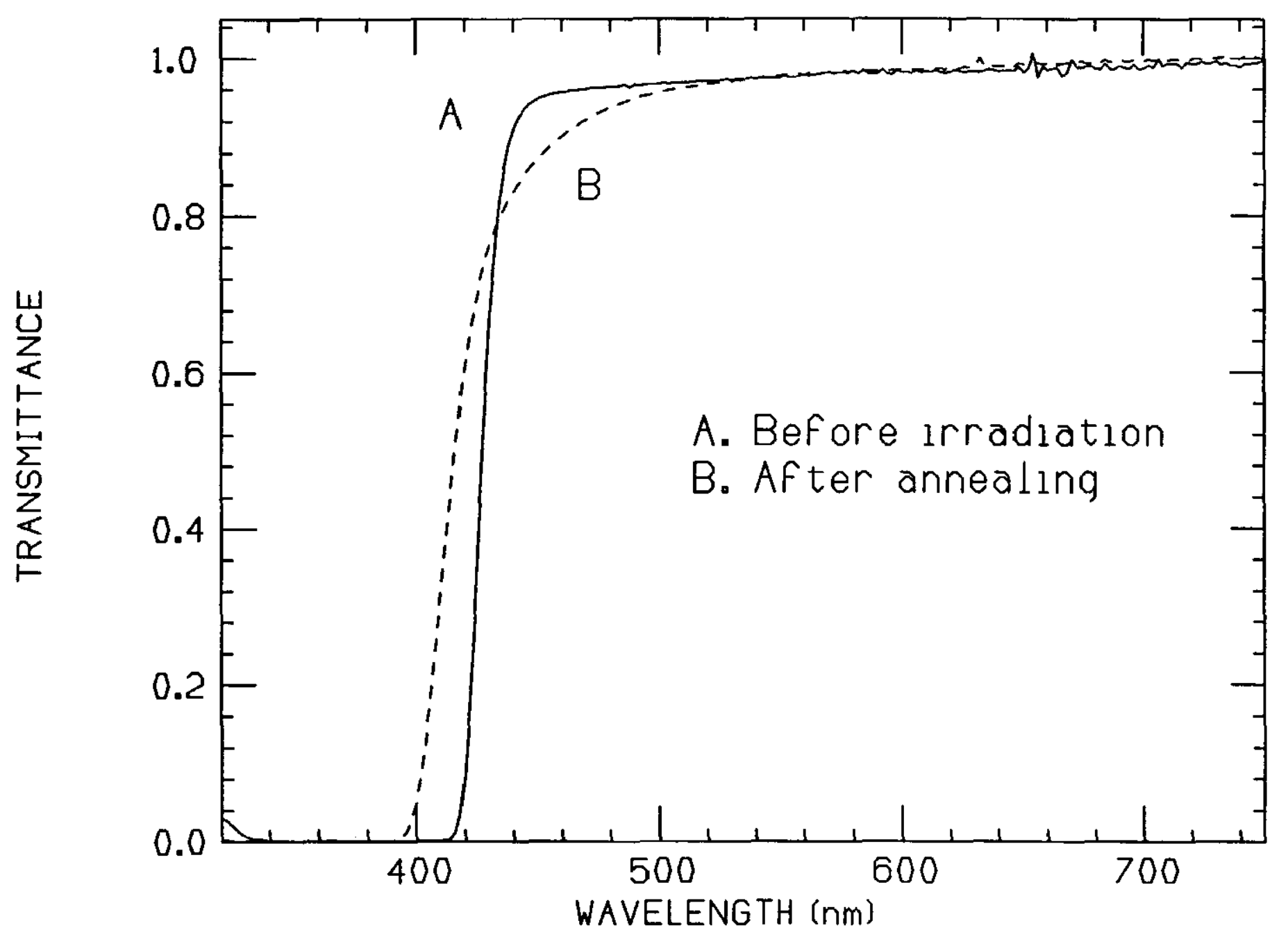




\subsection{2\% C500 - HIGH DOSE RATE IRRADIATION IN AIR}

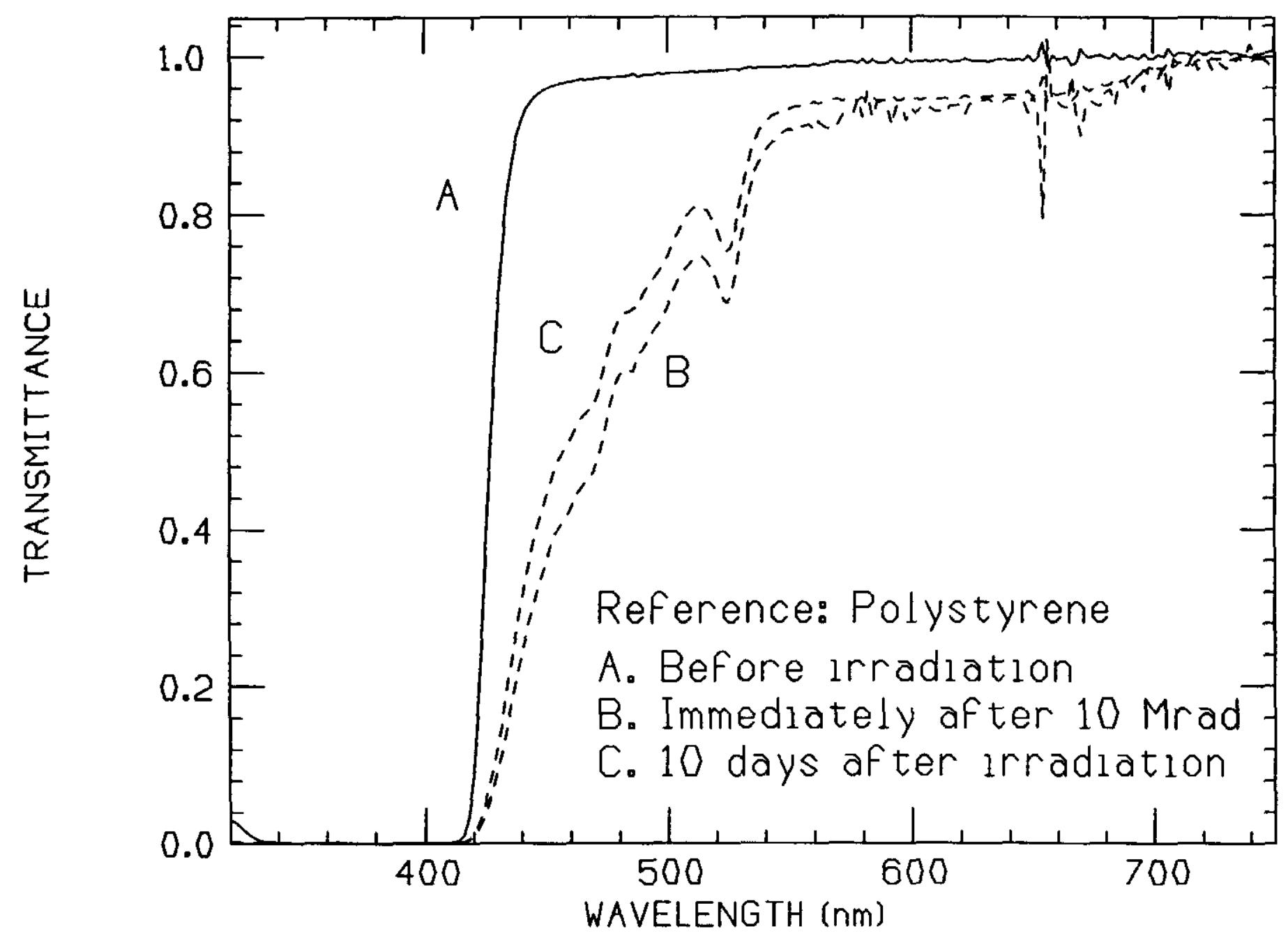


0.02\% C503 - HIGH DOSE RATE IRRADIATION IN AIR

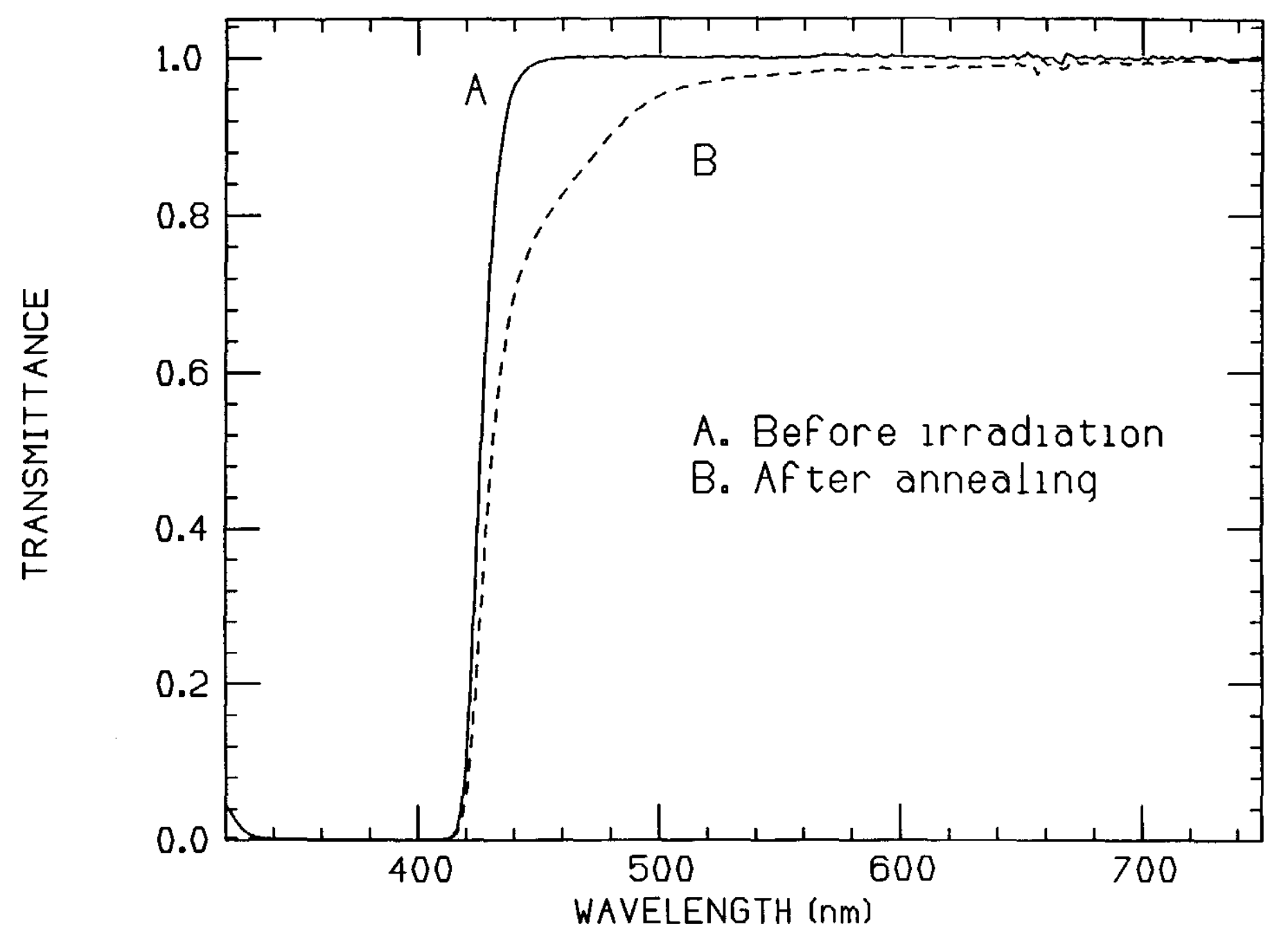


0.02\% C503 - HIGH DOSE RATE IRRADIATION IN AIR

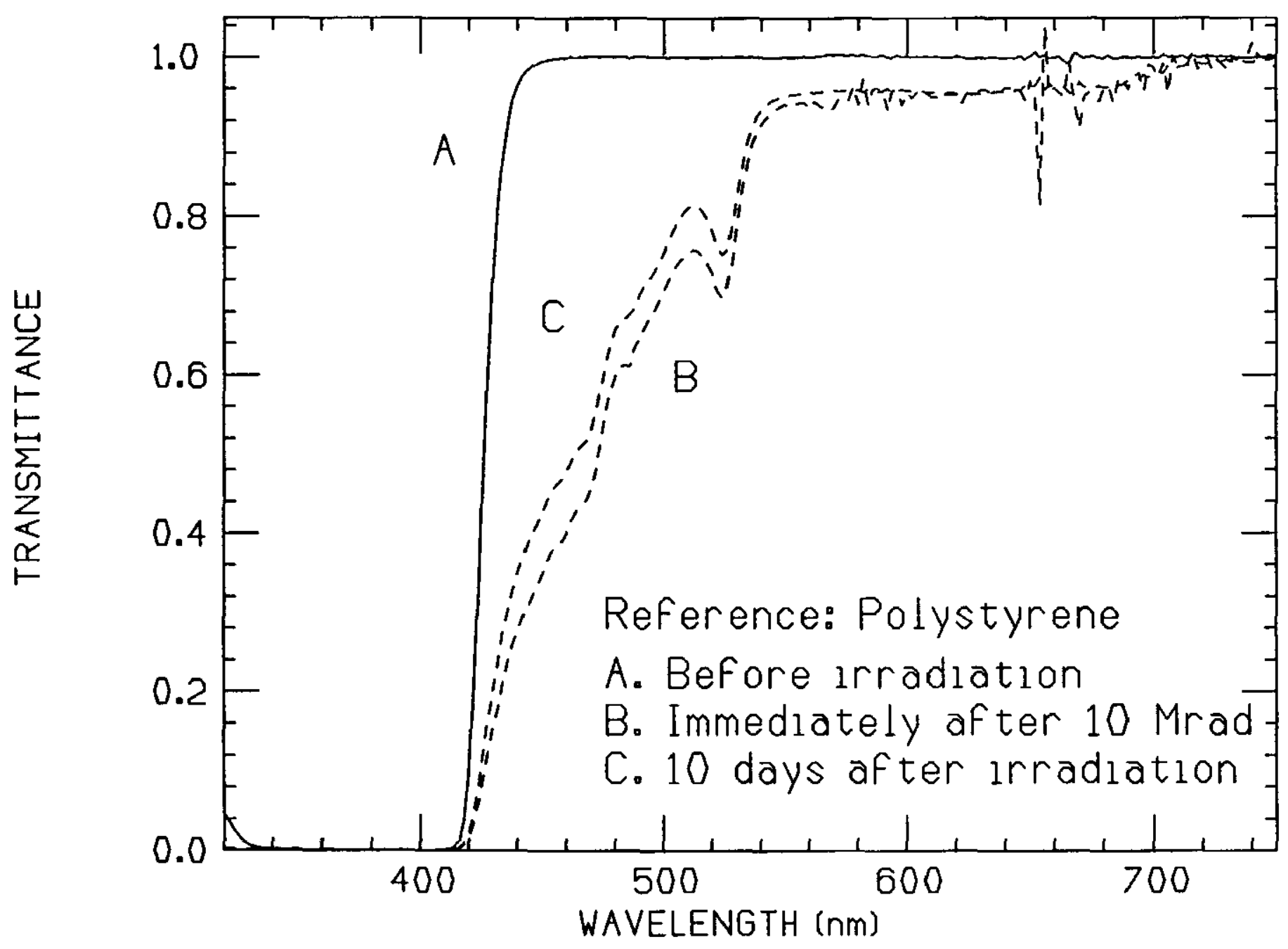


0.02\% C504 - HIGH DOSE RATE IRRADIATION IN AIR

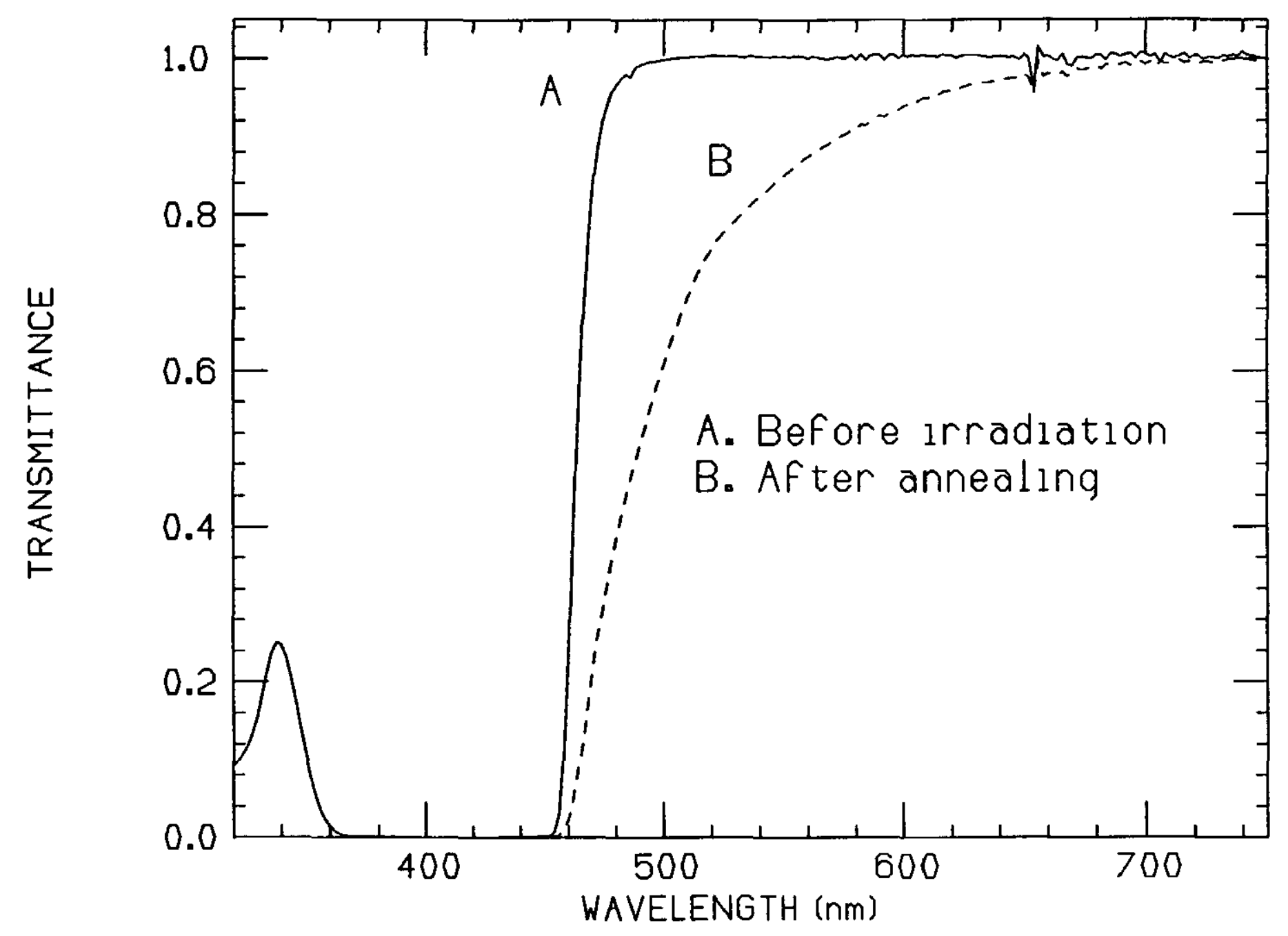




\subsection{2\% C504 - HIGH DOSE RATE IRRADIATION IN AIR}

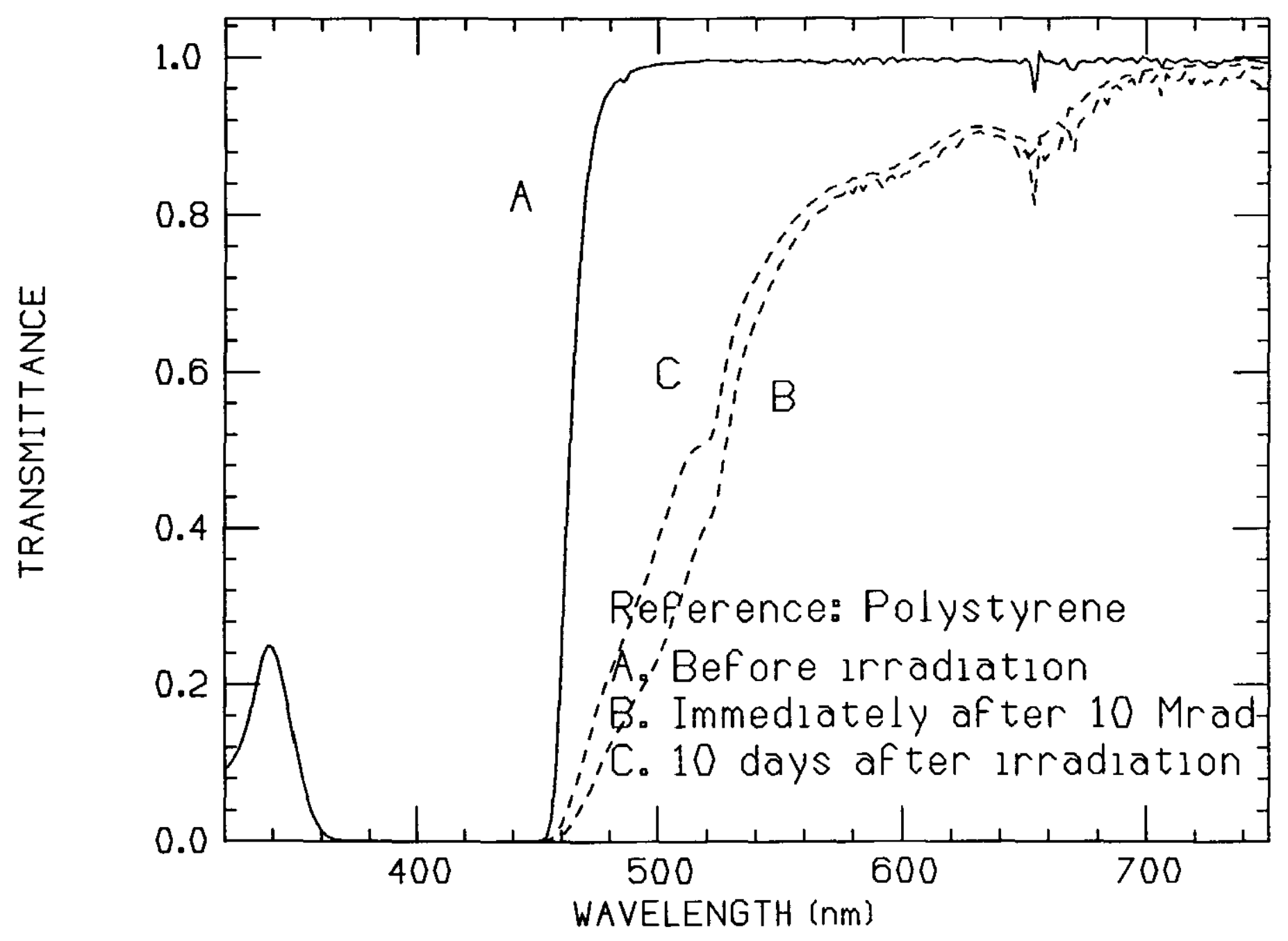




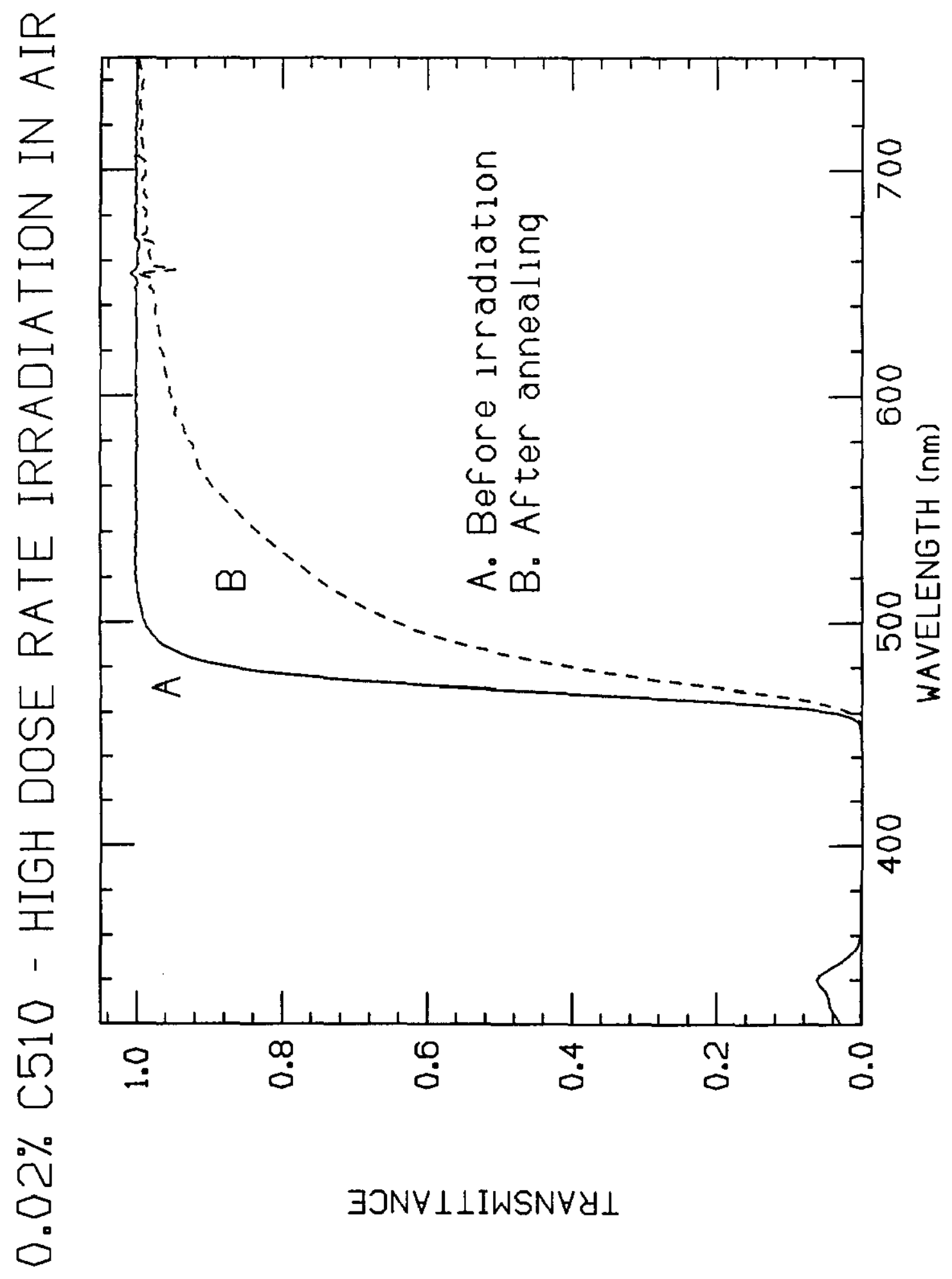




\subsection{2\% C510 - HIGH DOSE RATE IRRADIATION IN AIR}

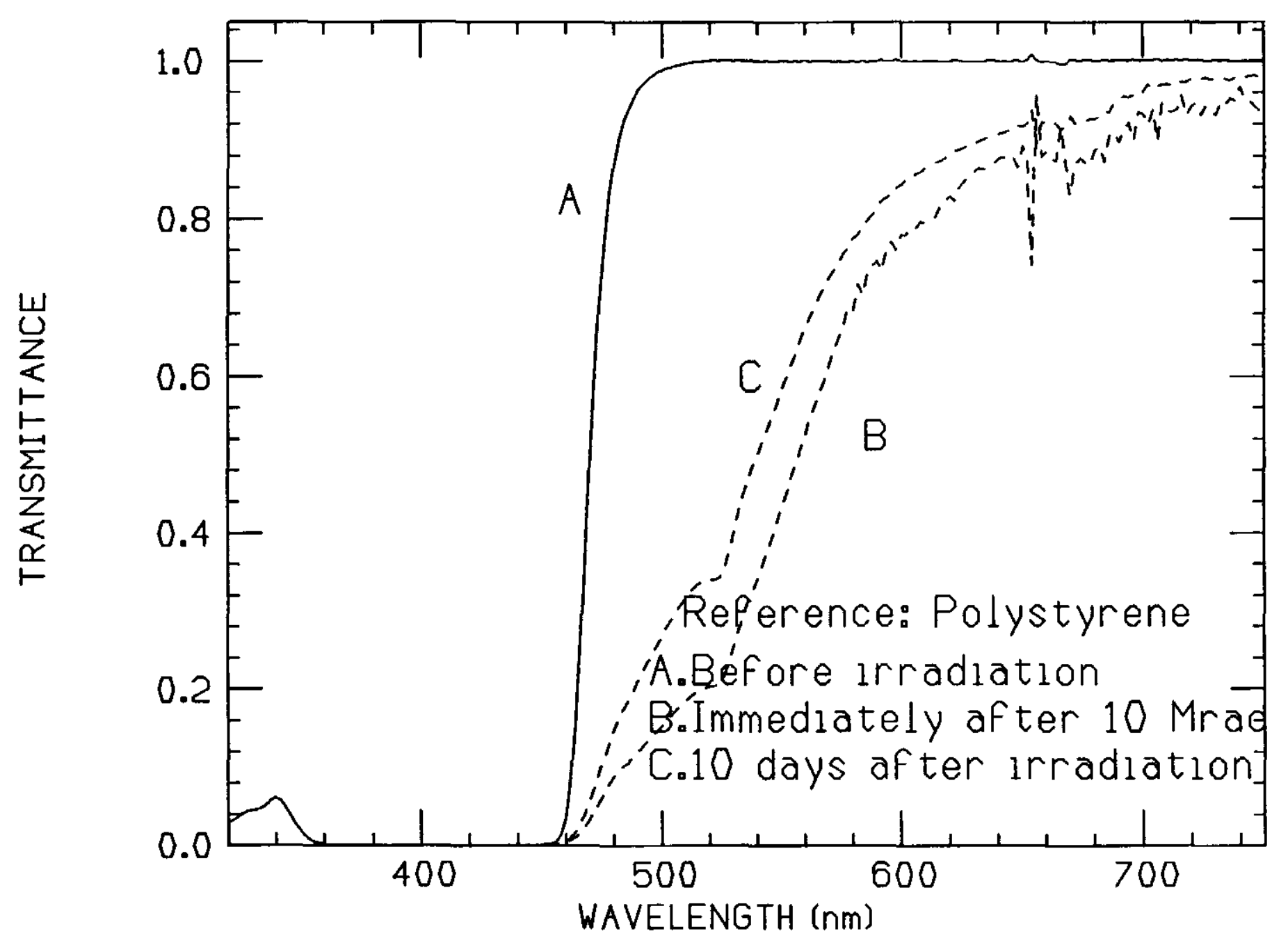


0.02\% C515 - HIGH DOSE RATE IRRADIATION IN AIR

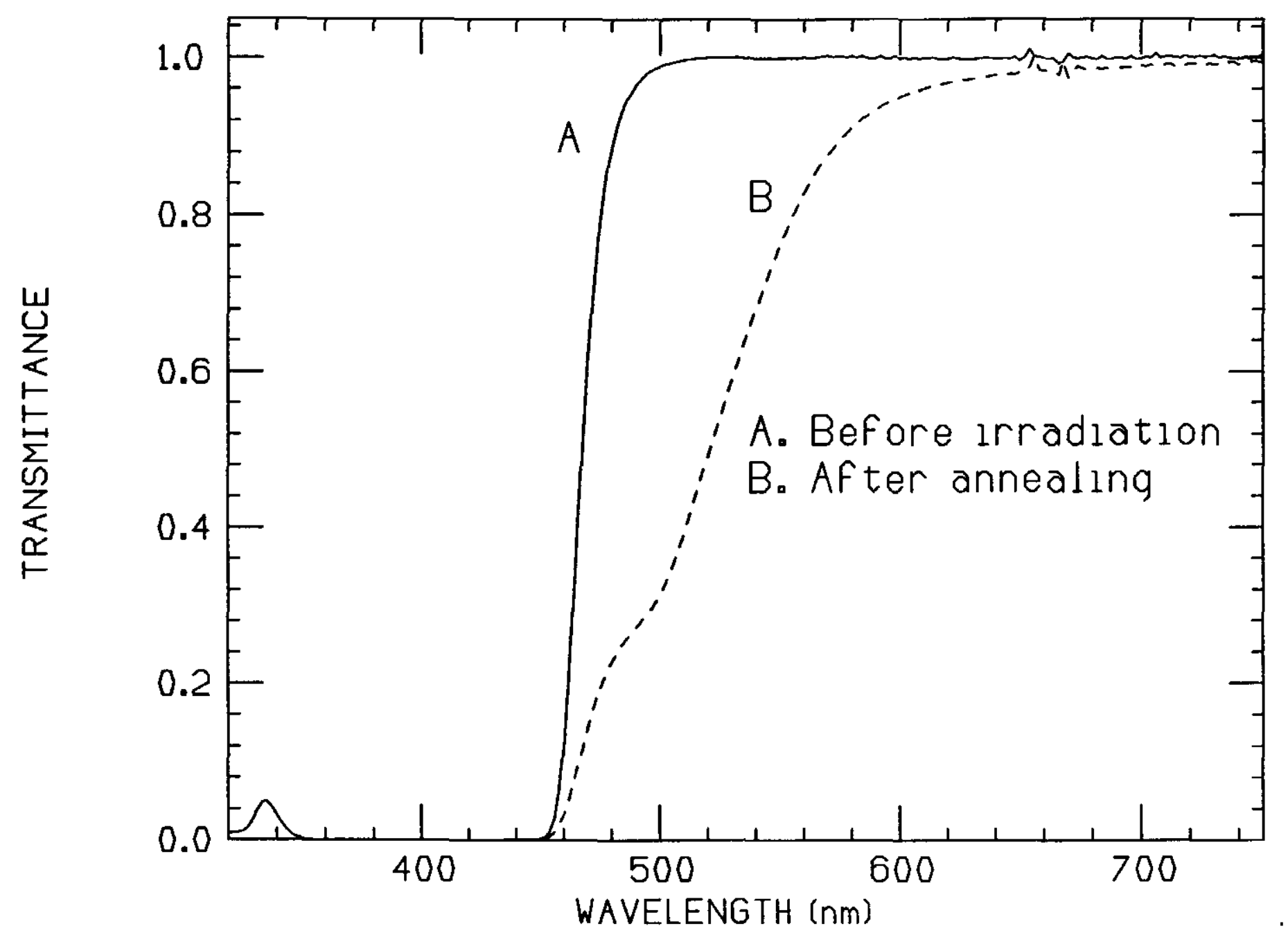




\subsection{2\% C515 - HIGH DOSE RATE IRRADIATION IN AIR}

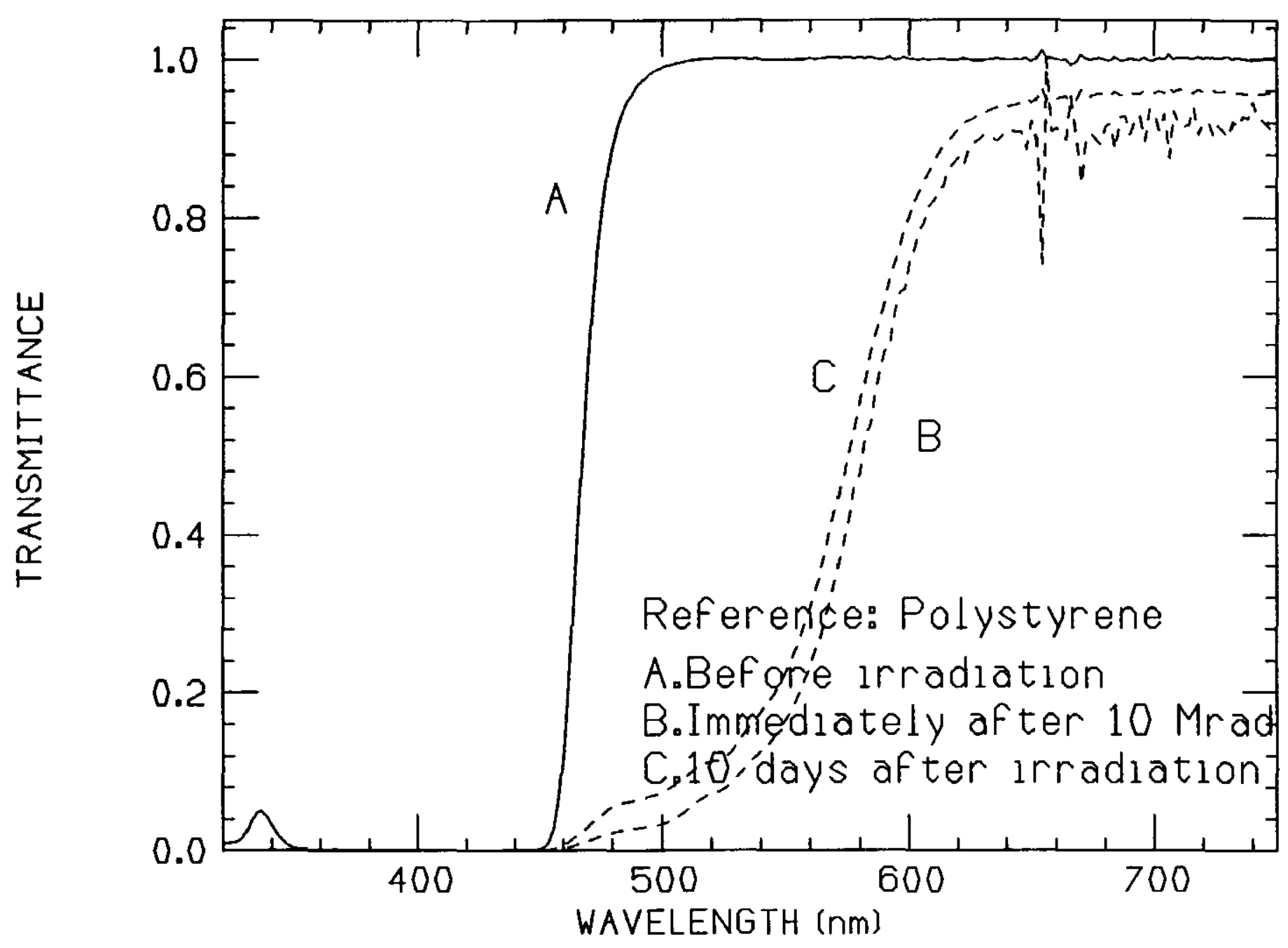




\subsection{2\% C519 - HIGH DOSE RATE IRRADIATION IN AIR}

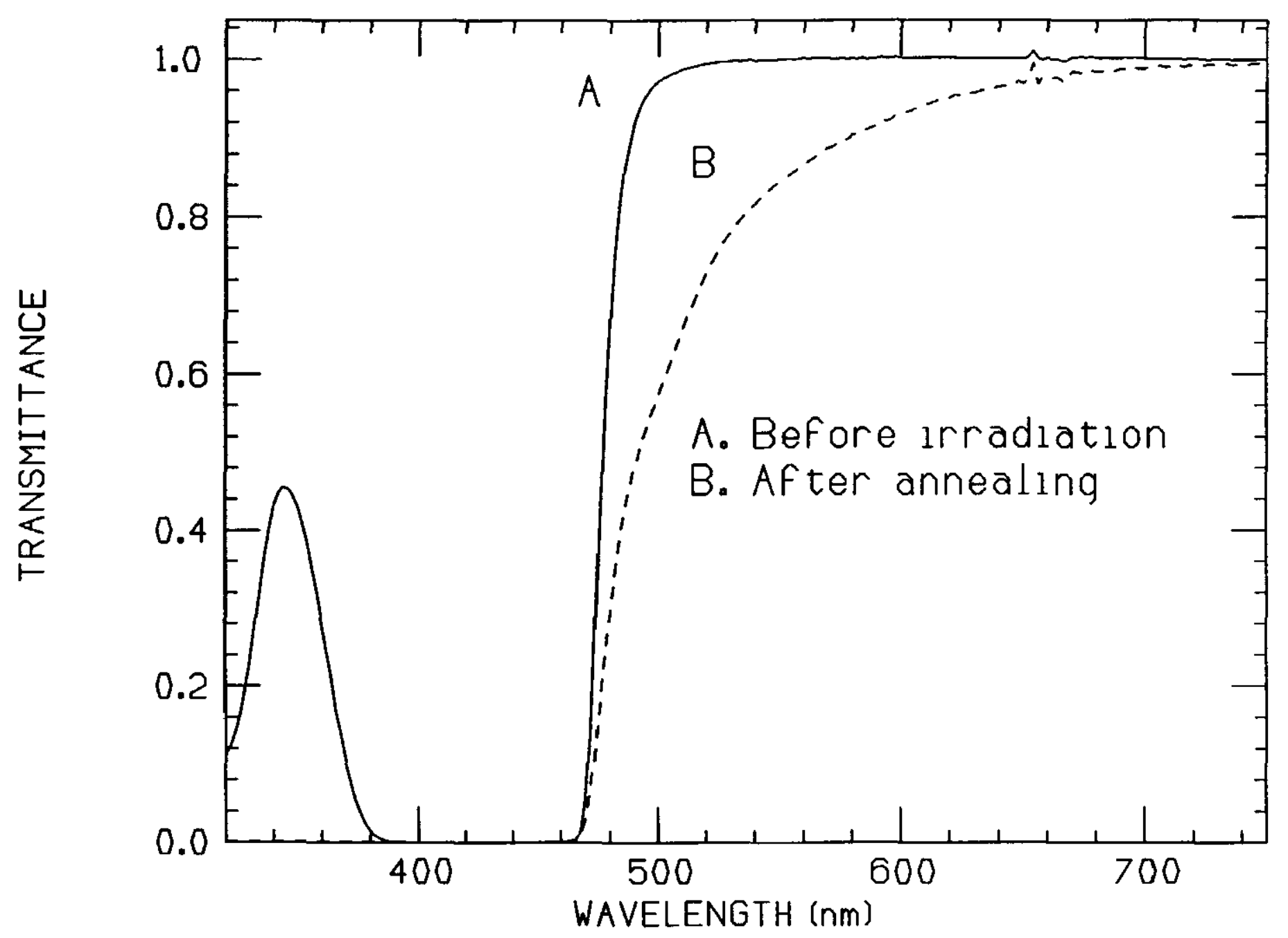




\subsection{2\% C519 - HIGH DOSE RATE IRRADIATION IN AIR}

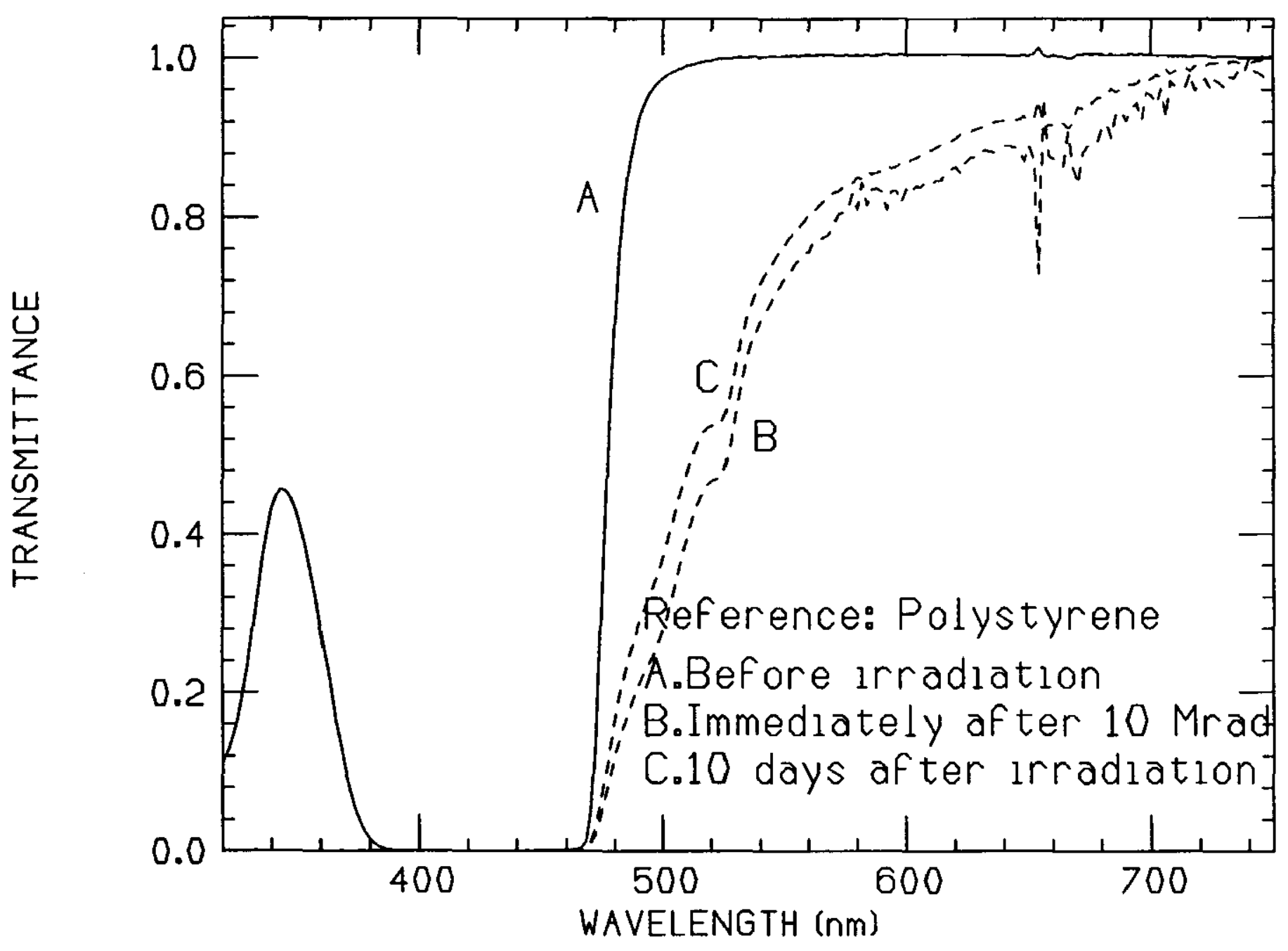


0.02\% C521 - HIGH DOSE RATE IRRADIATION IN AIR

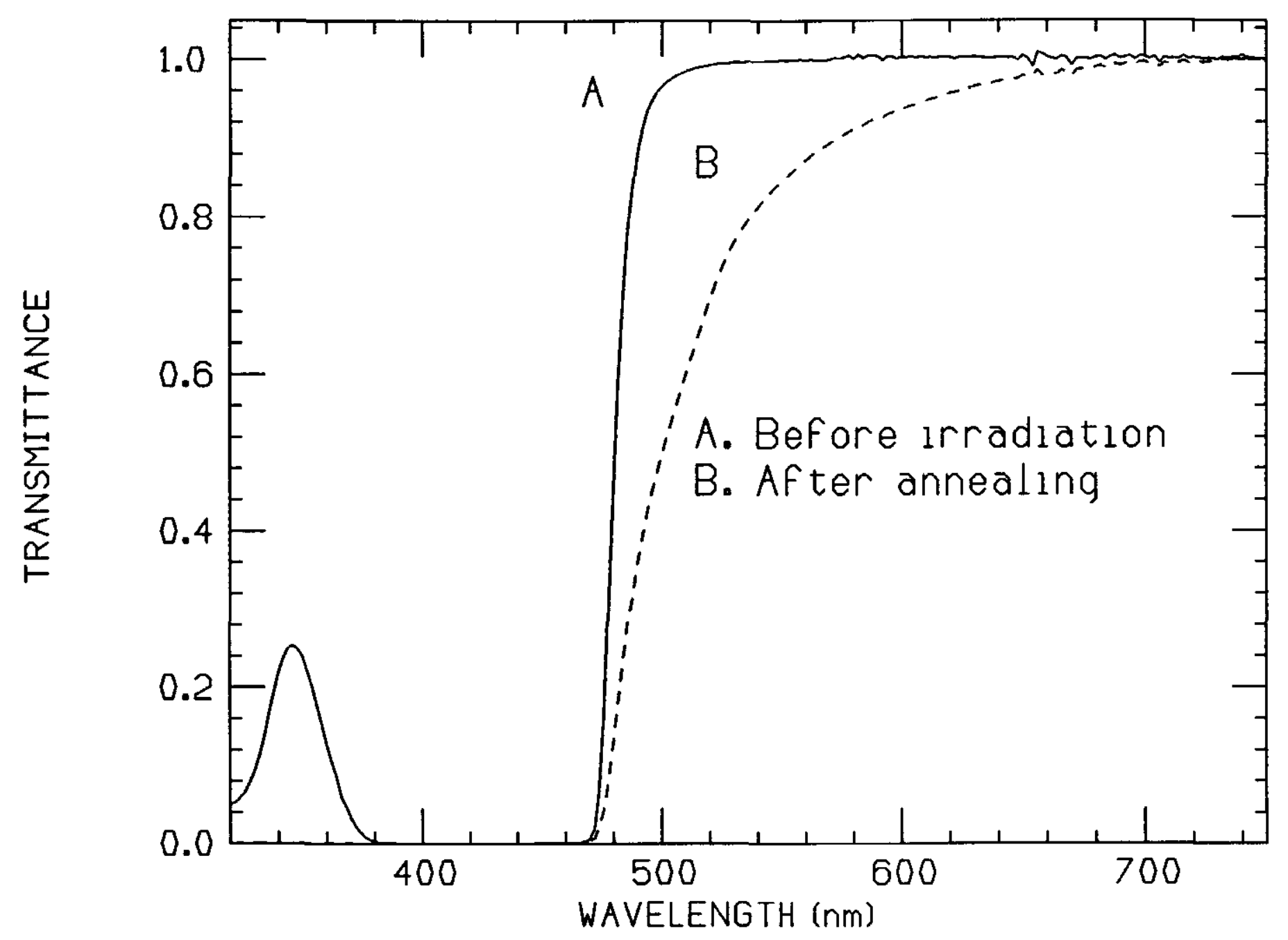


0.02\% C521 - HIGH DOSE RATE IRRADIATION IN AIR

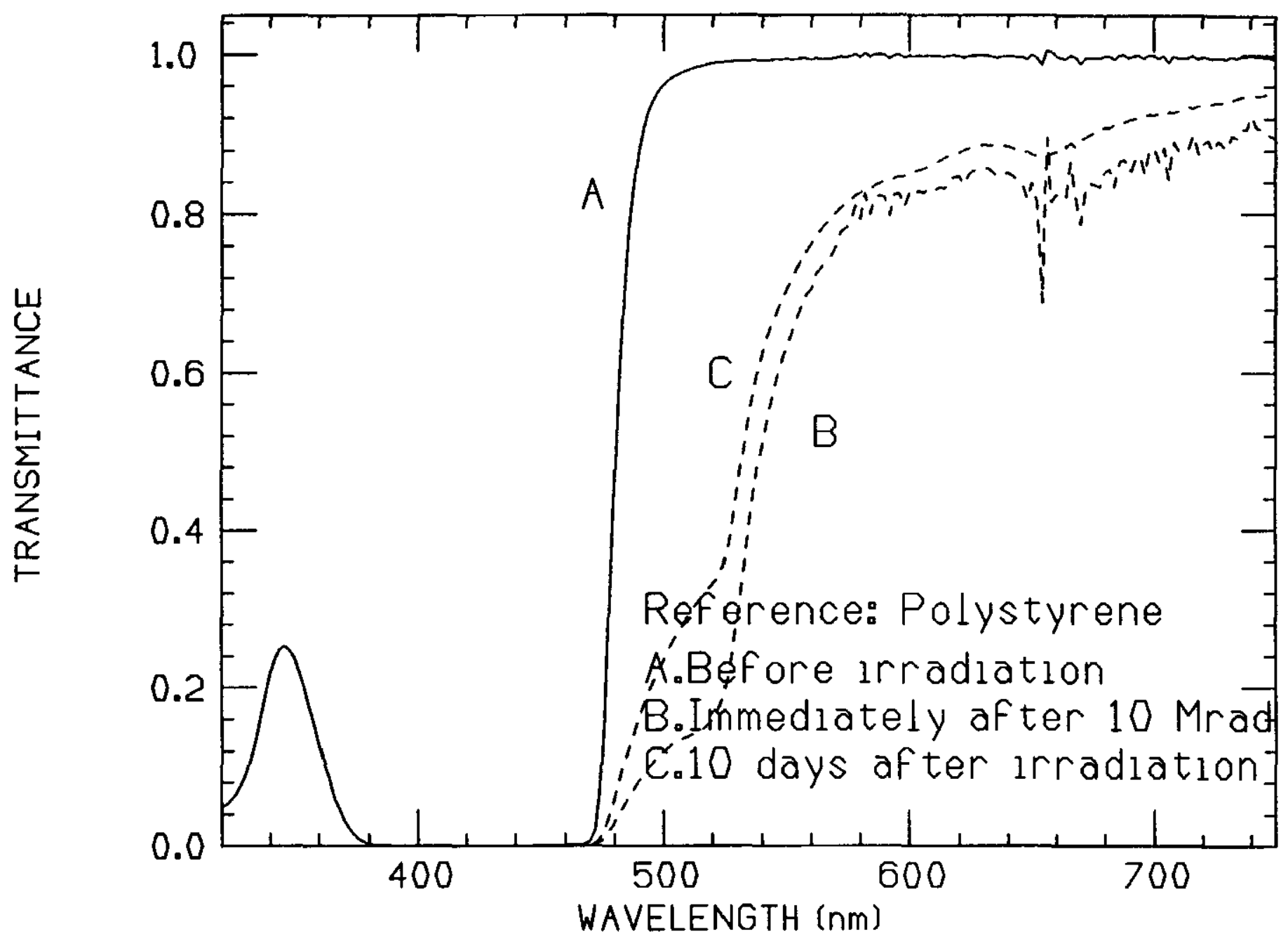


0.02\% C522 - HIGH DOSE RATE IRRADIATION IN AIR

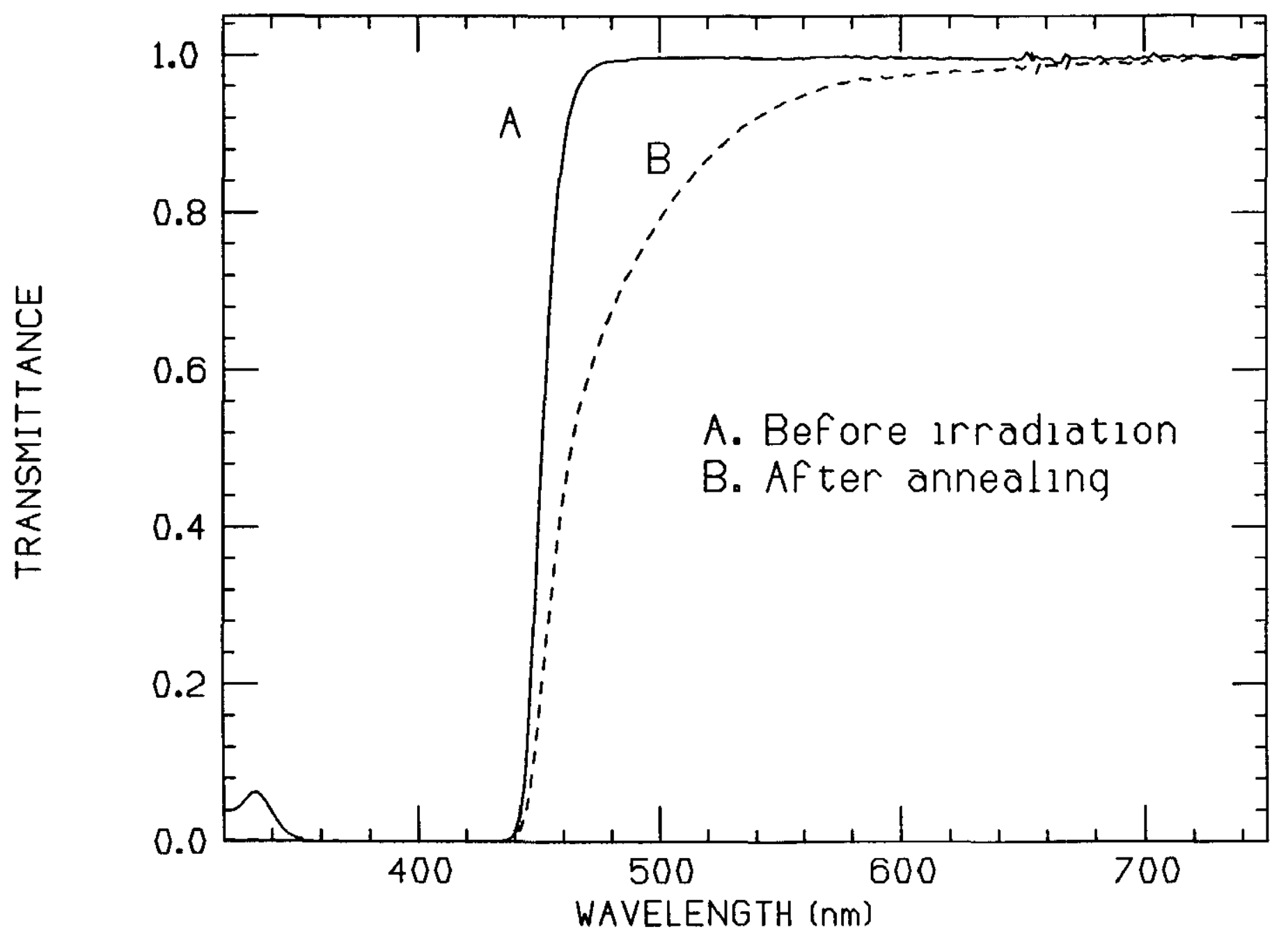




\subsection{2\% C522 - HIGH DOSE RATE IRRADIATION IN AIR}

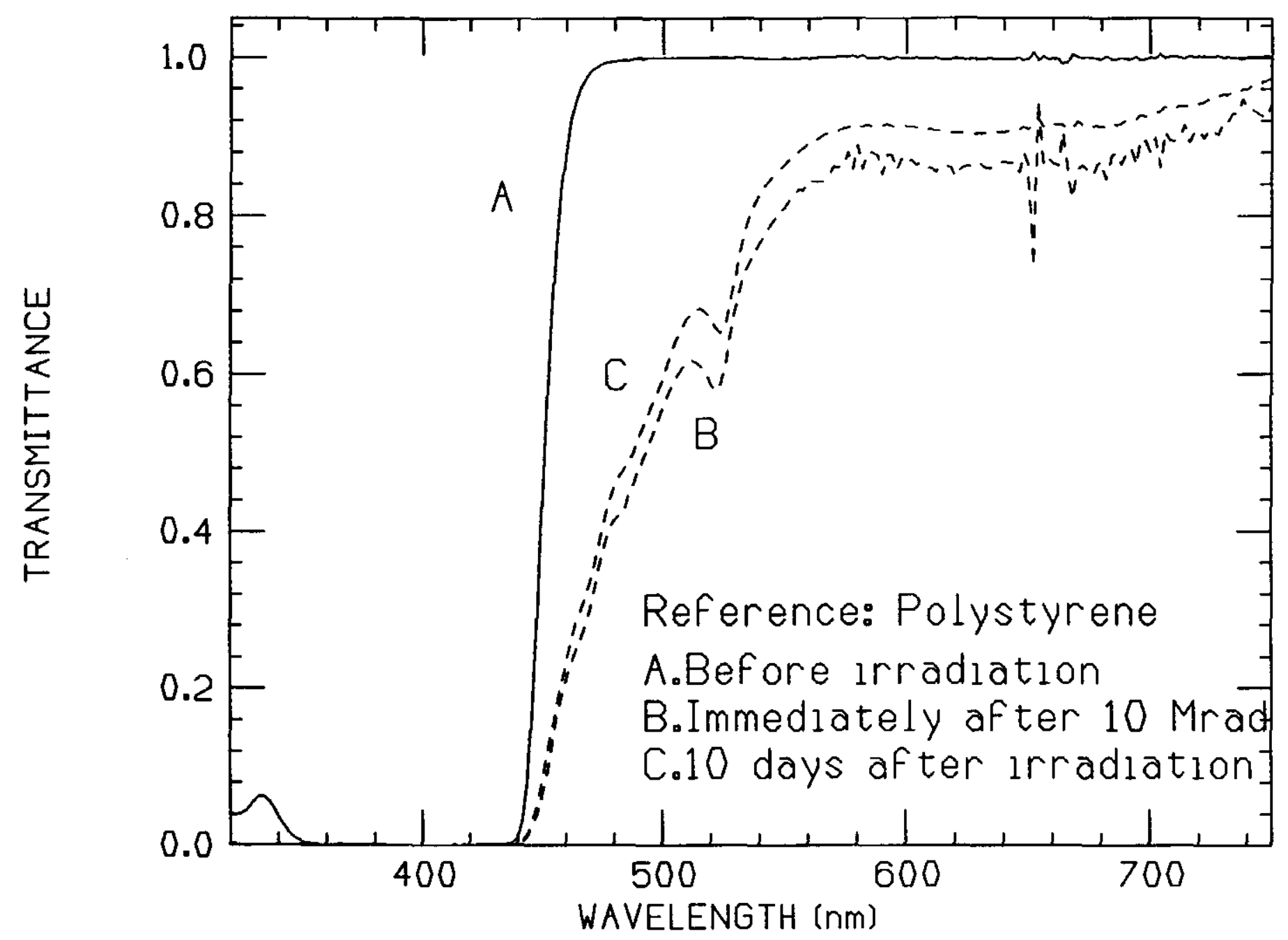


$0.02 \%$ C523 - HIGH DOSE RATE IRRADIATION IN AIR

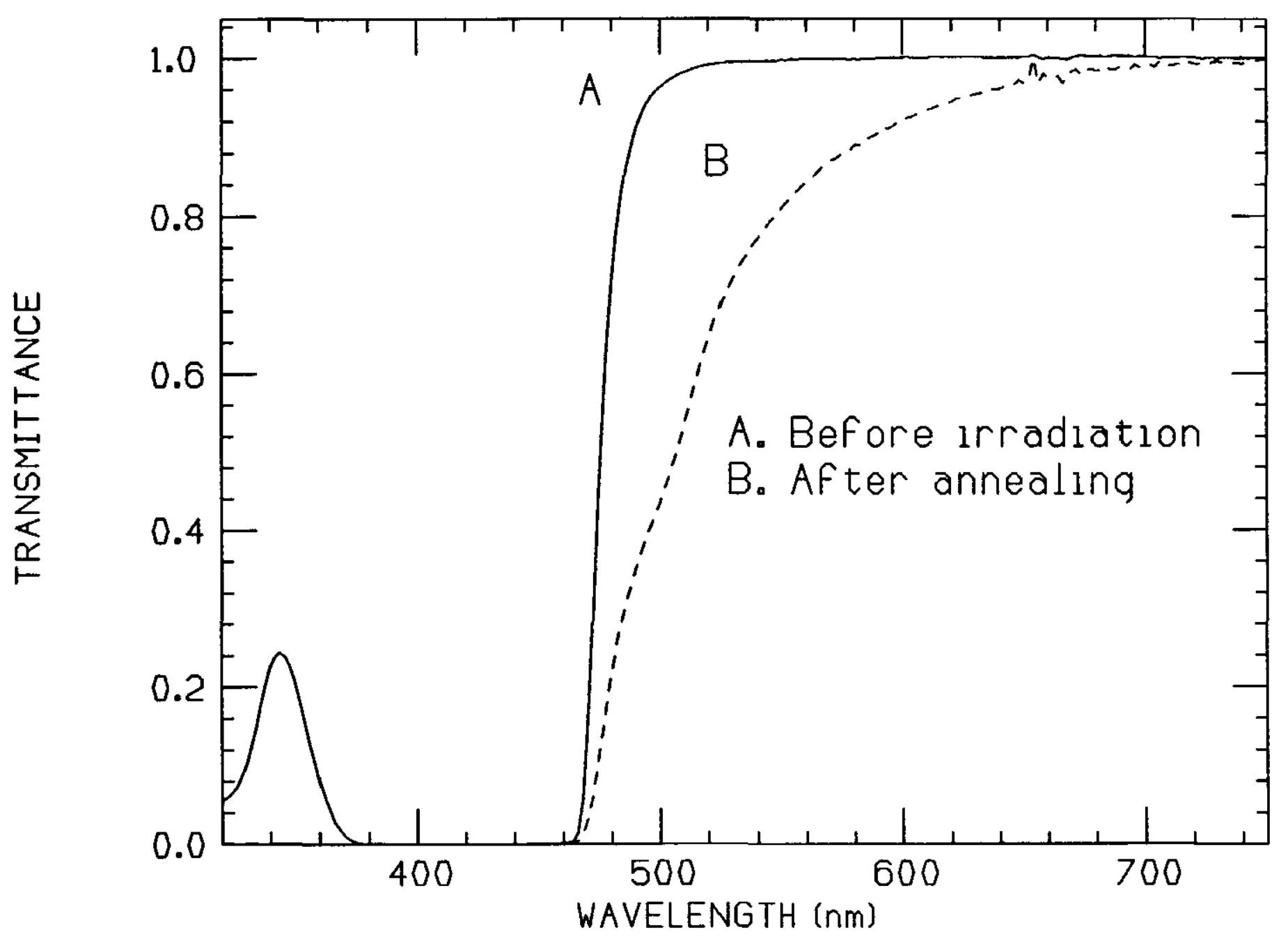


0.02\% C523 - HIGH DOSE RATE IRRADIATION IN AIR

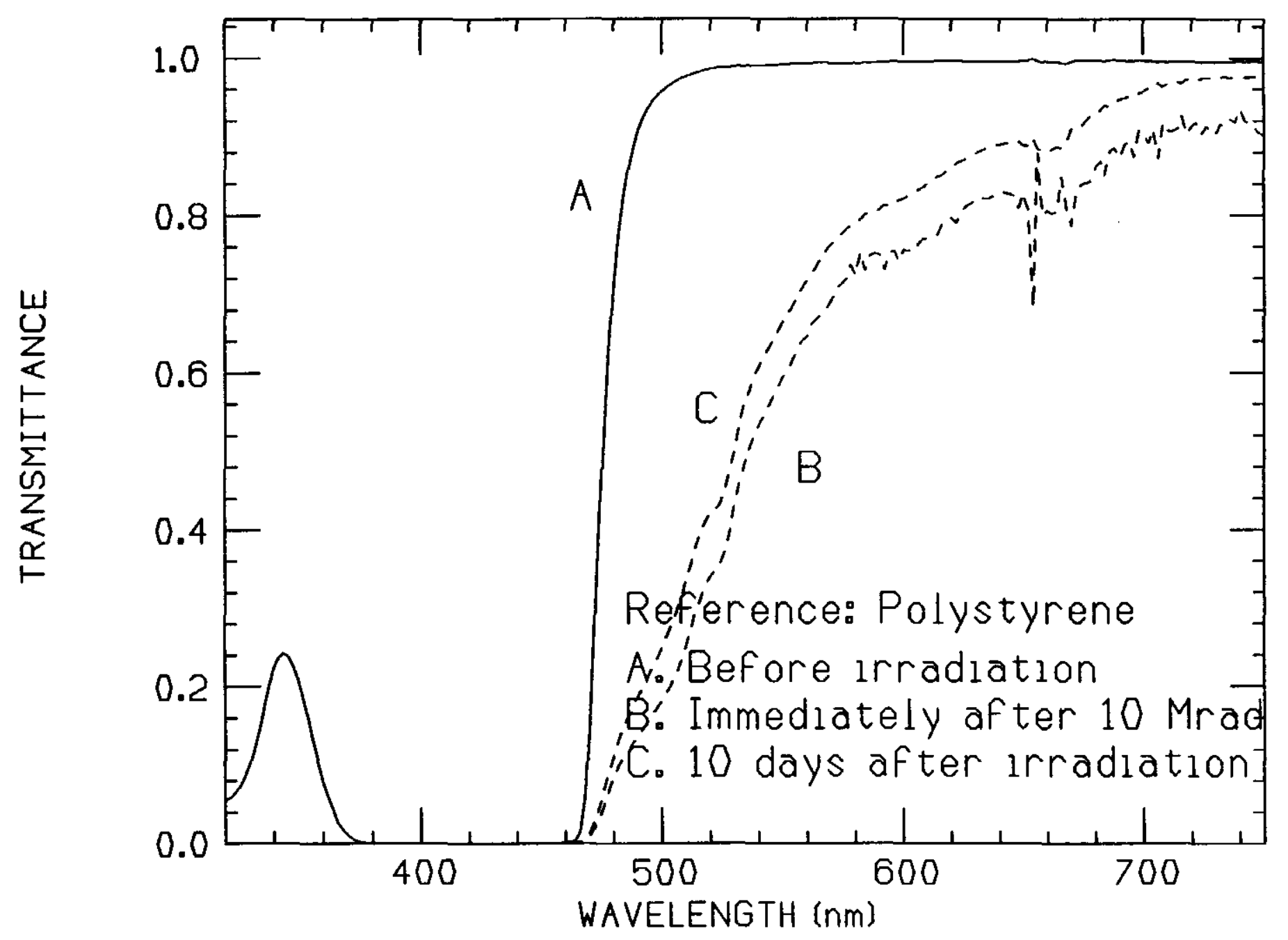


$0.02 \%$ C525 - HIGH DOSE RATE IRRADIATION IN AIR

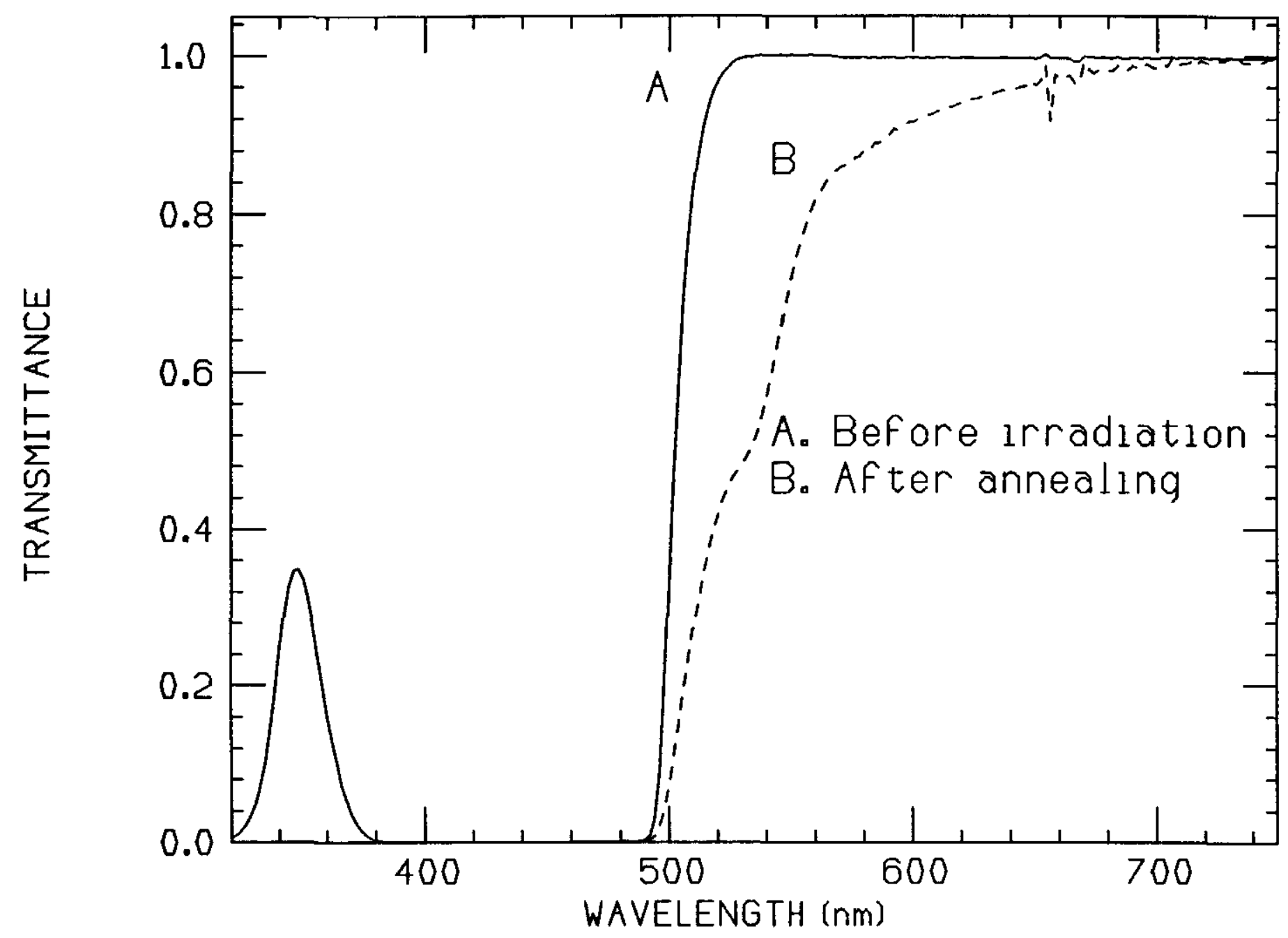


0.02\% C525 - HIGH DOSE RATE IRRADIATION IN AIR

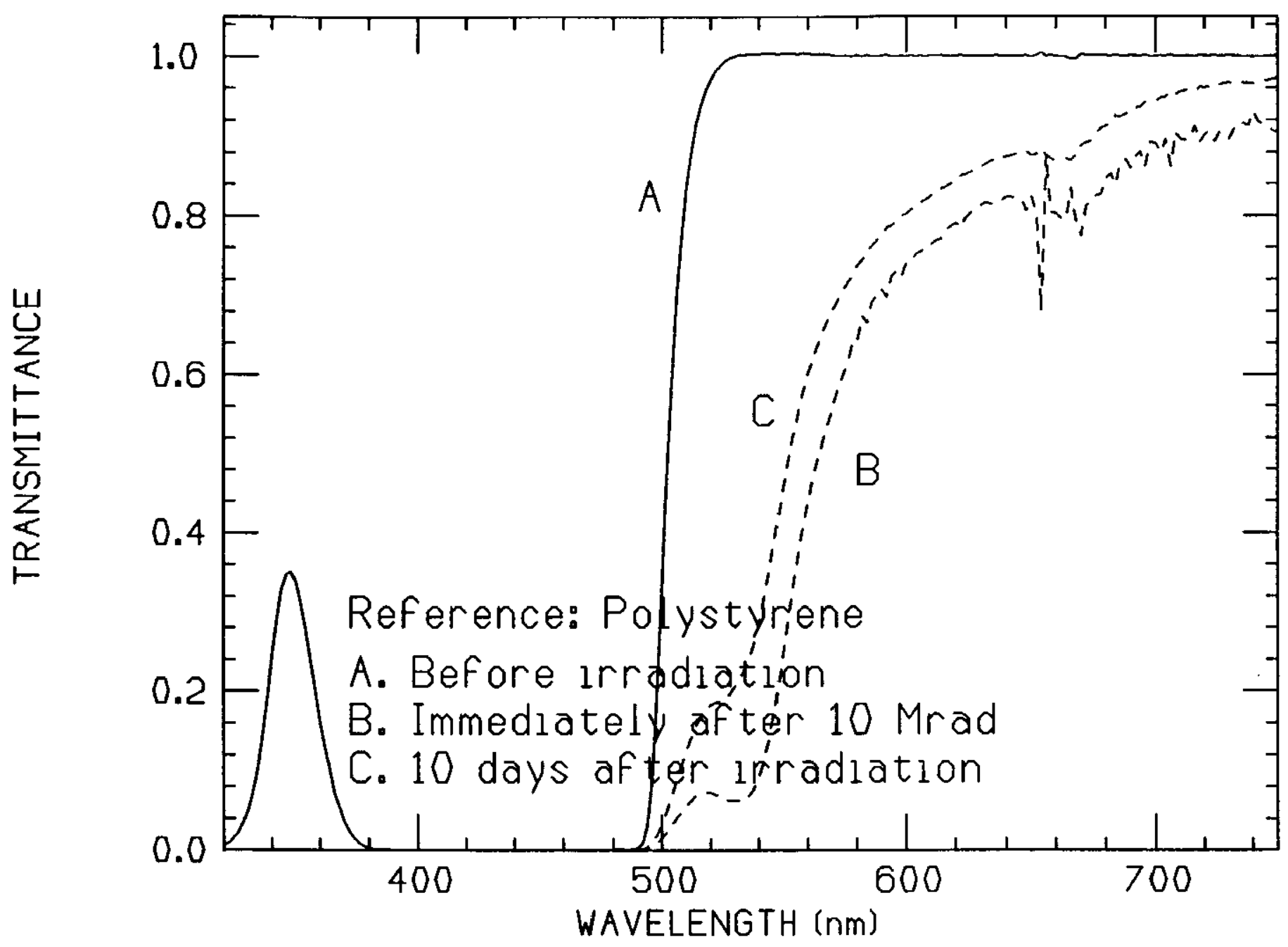


0.02\% C535 - HIGH DOSE RATE IRRADIATION IN AIR

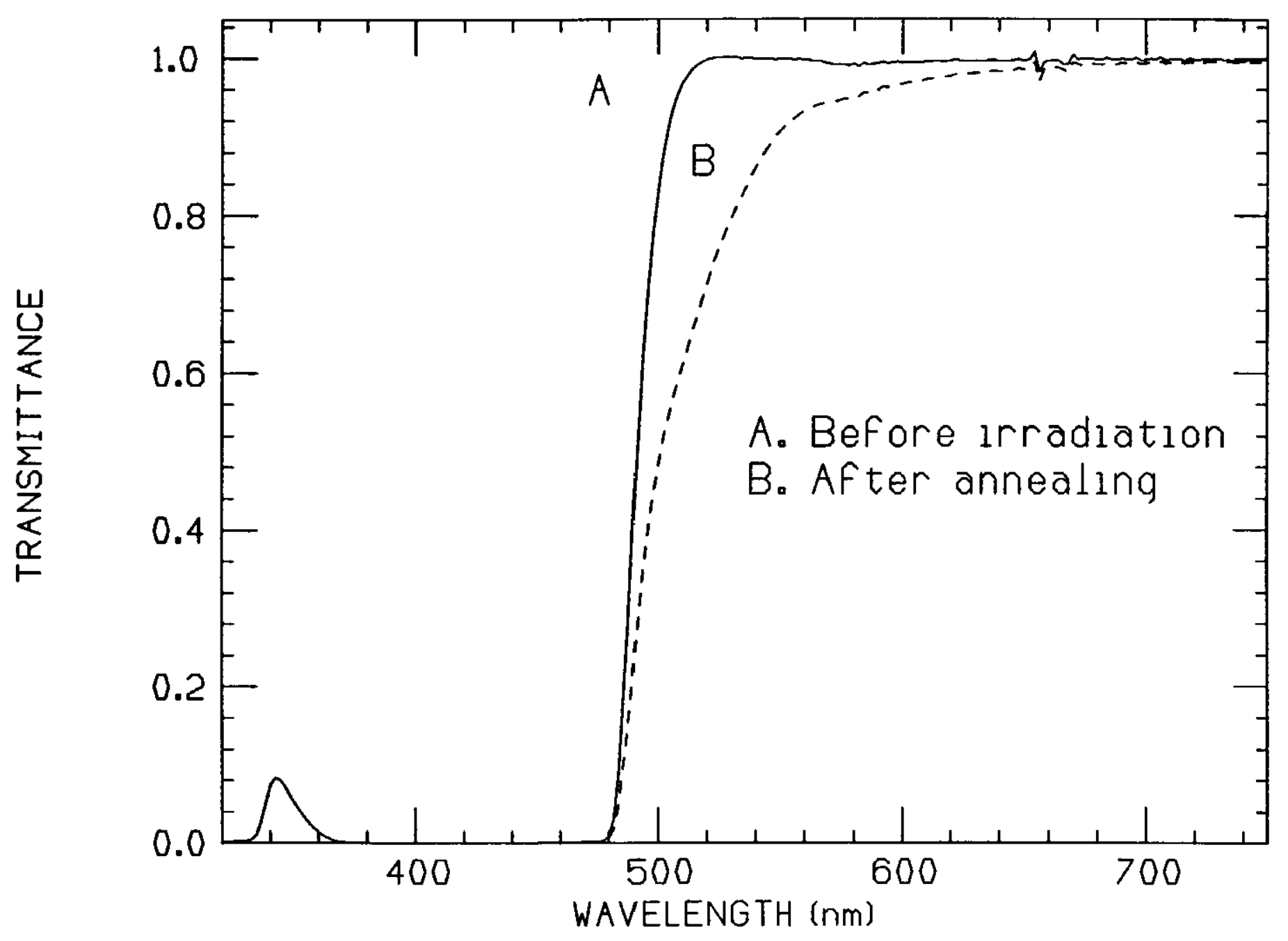


0.02\% C535 - HIGH DOSE RATE IRRADIATION IN AIR

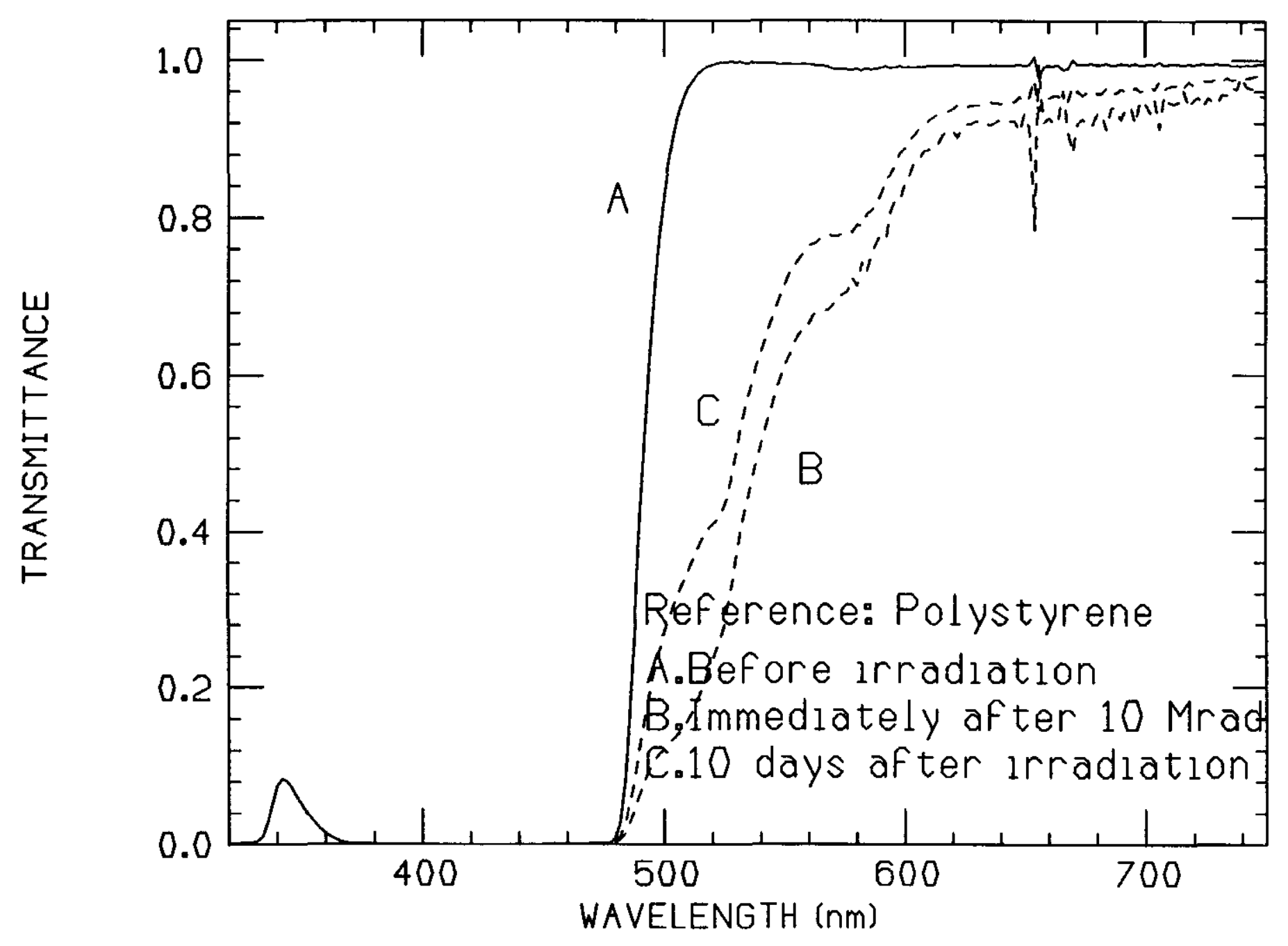


0.02\% C540 - HIGH DOSE RATE IRRADIATION IN AIR

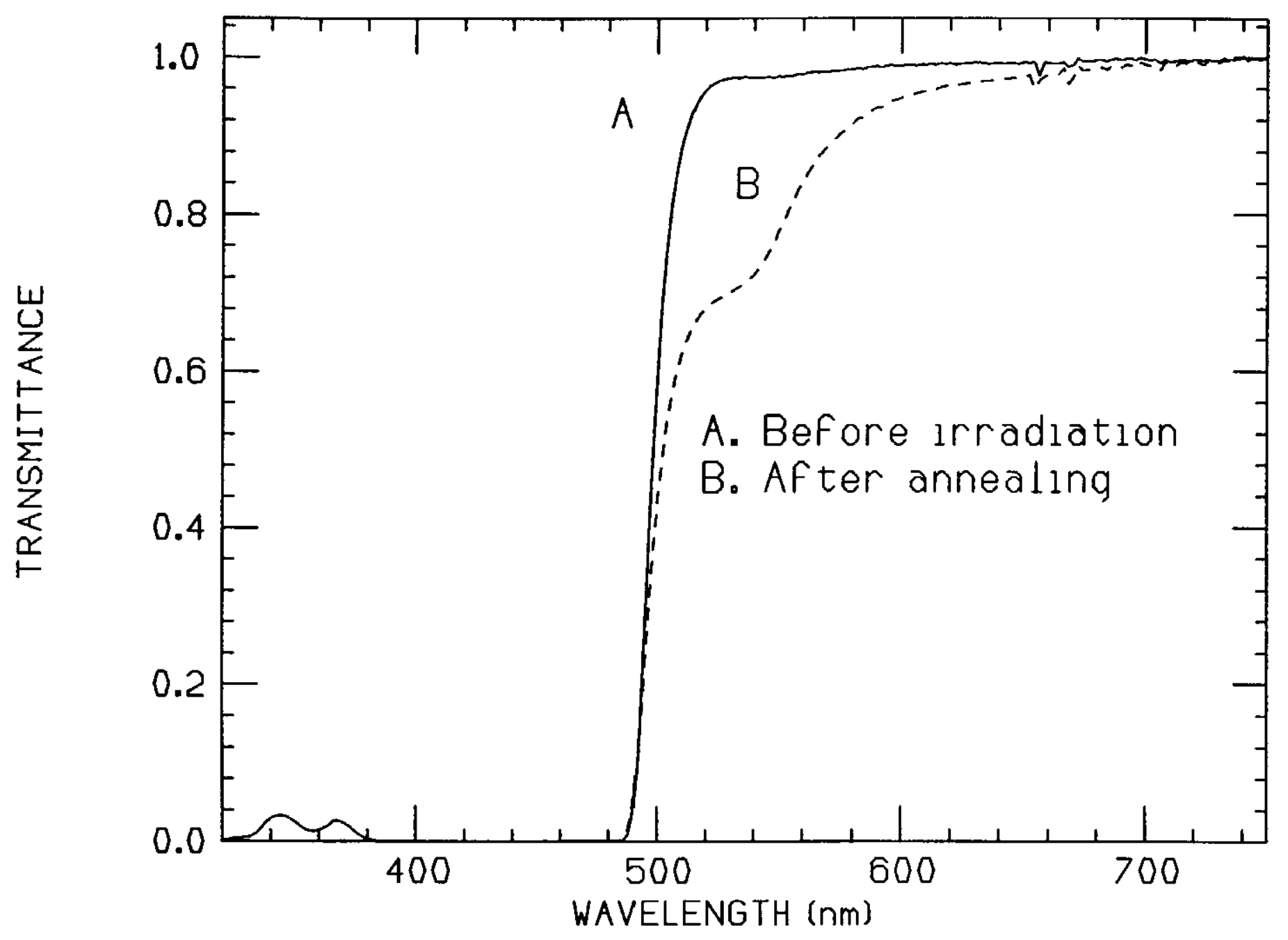




\subsection{2\% C540 - HIGH DOSE RATE IRRADIATION IN AIR}

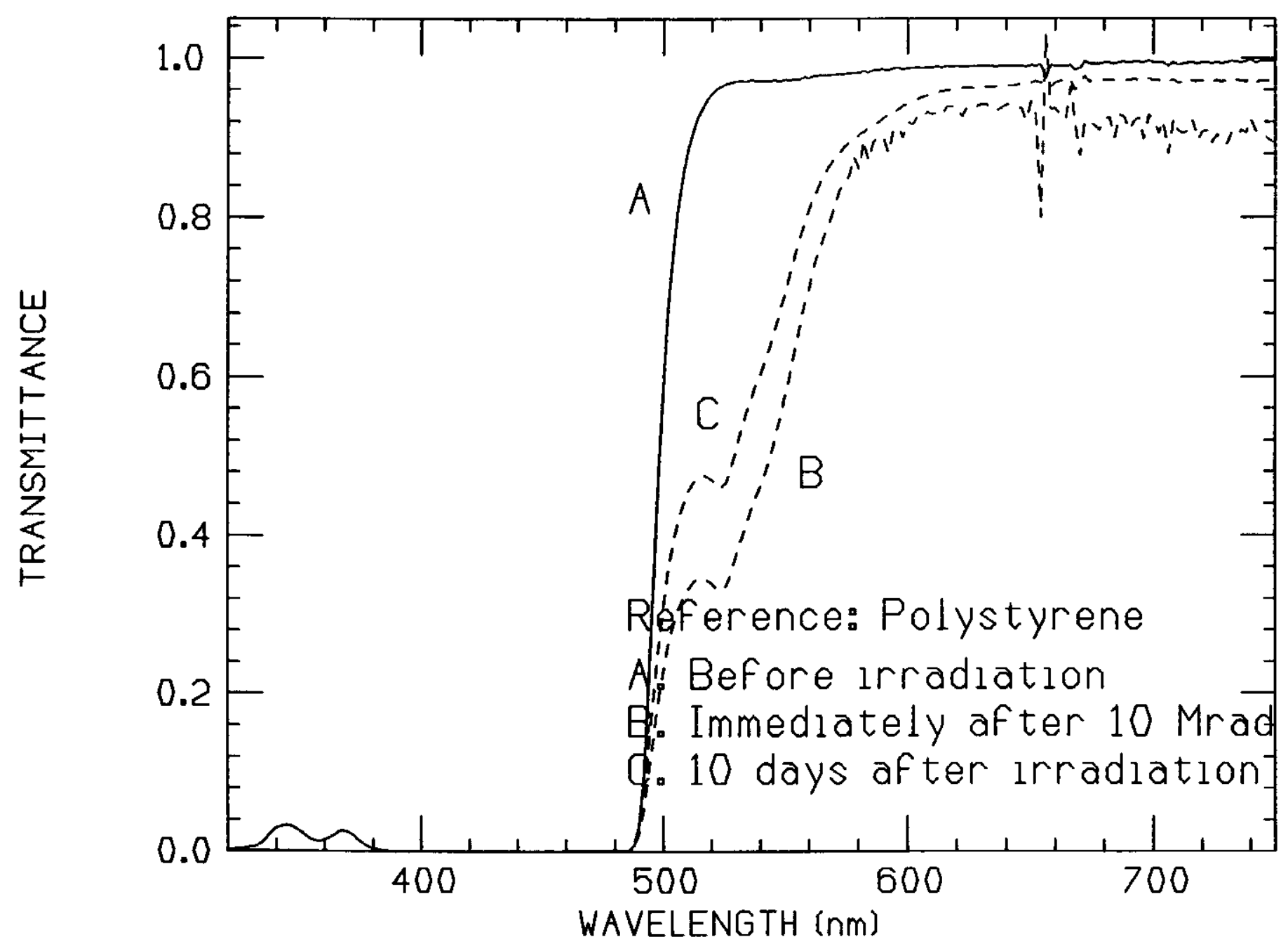


0.02\% C545 - HIGH DOSE RATE IRRADIATION IN AIR

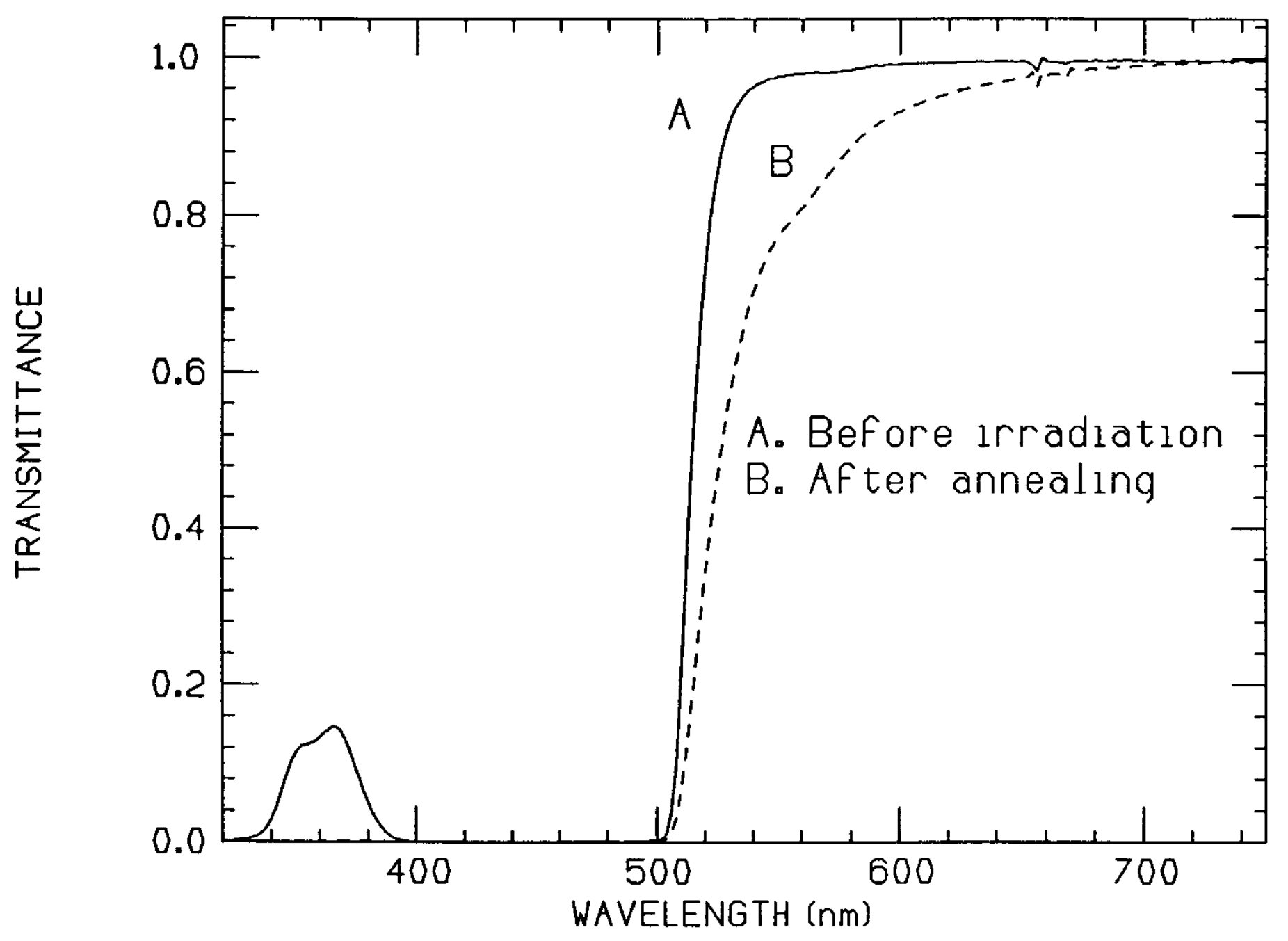


$0.02 \%$ C545 - HIGH DOSE RATE IRRADIATION IN AIR

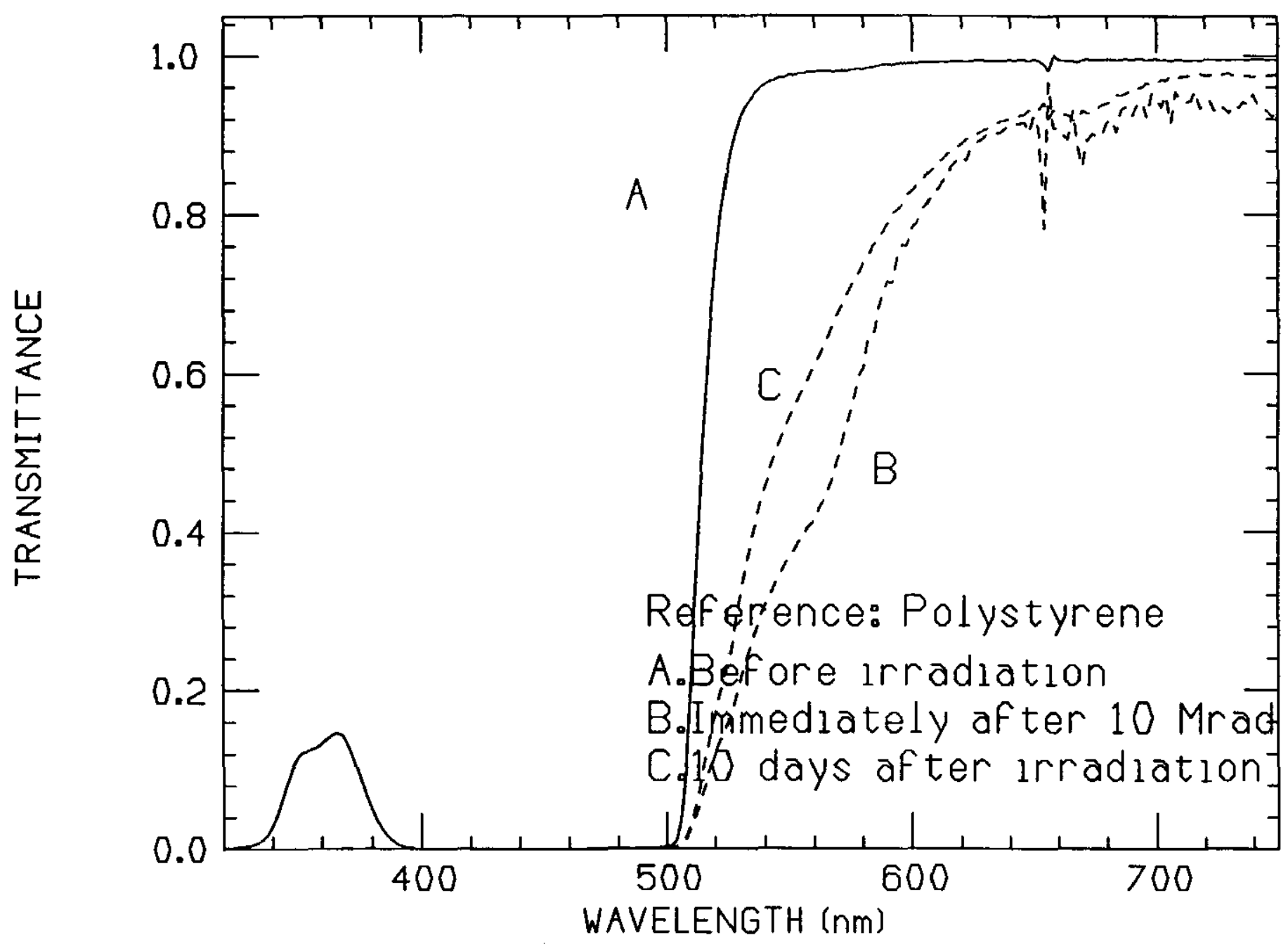


0.02\% LPY - HIGH DOSE RATE IRRADIATION IN AIR

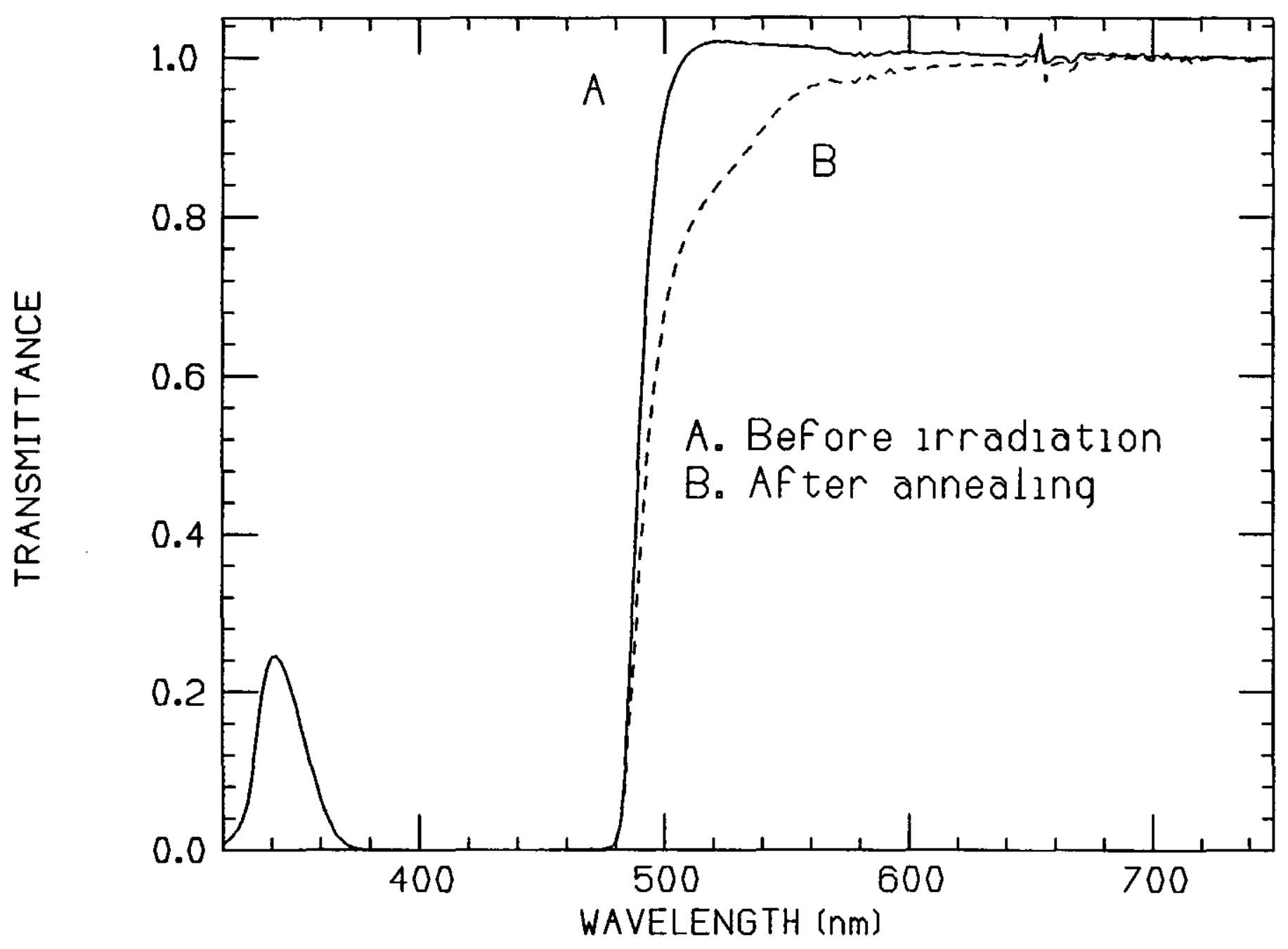




\subsection{2\% LPY - HIGH DOSE RATE IRRADIATION IN AIR}

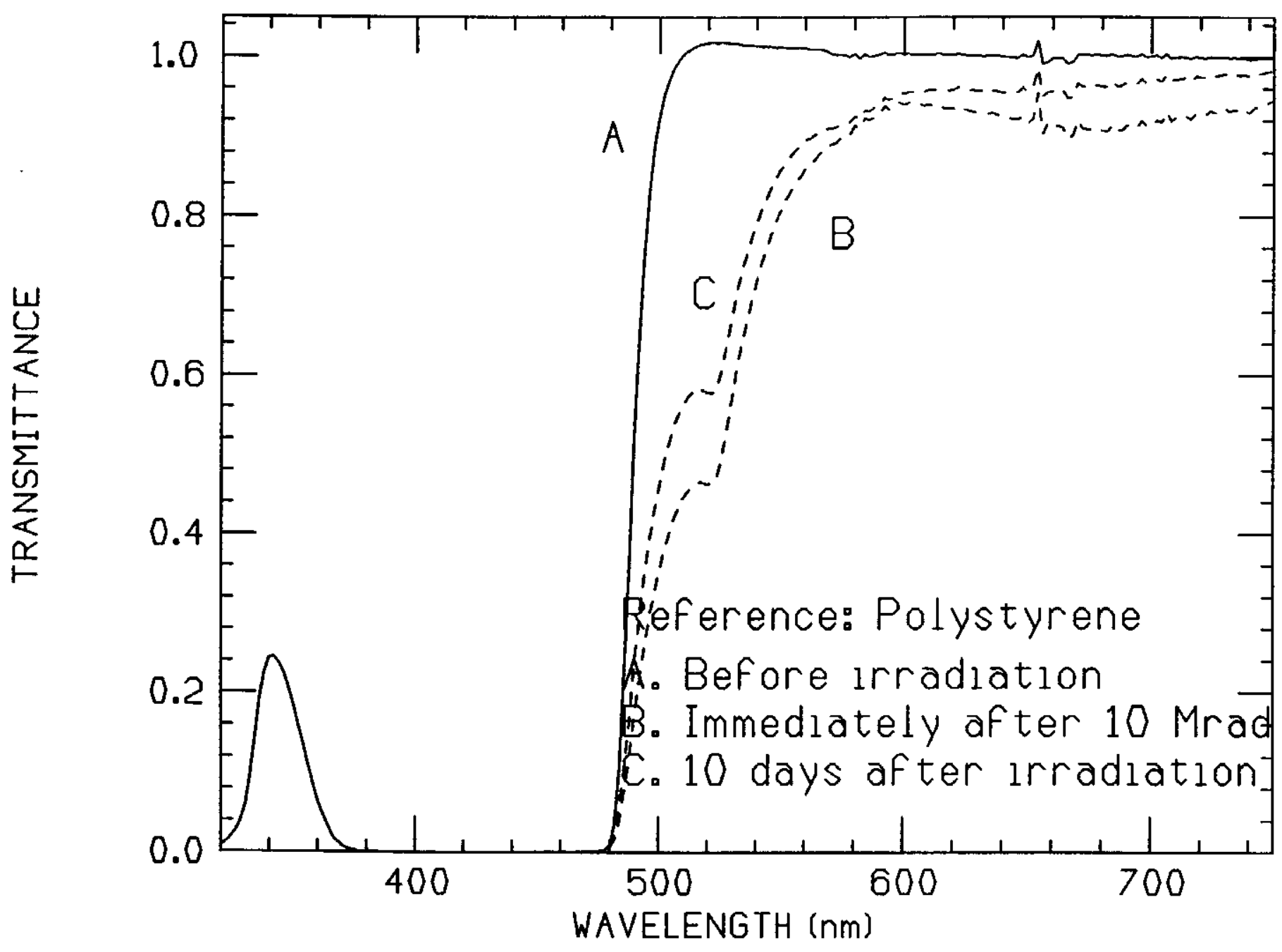


PART II

RADIATION DAMAGE SET \#22 
0.02\% ACRIDINE OB-HIGH DOSE RATE IRRADIATION IN AIR

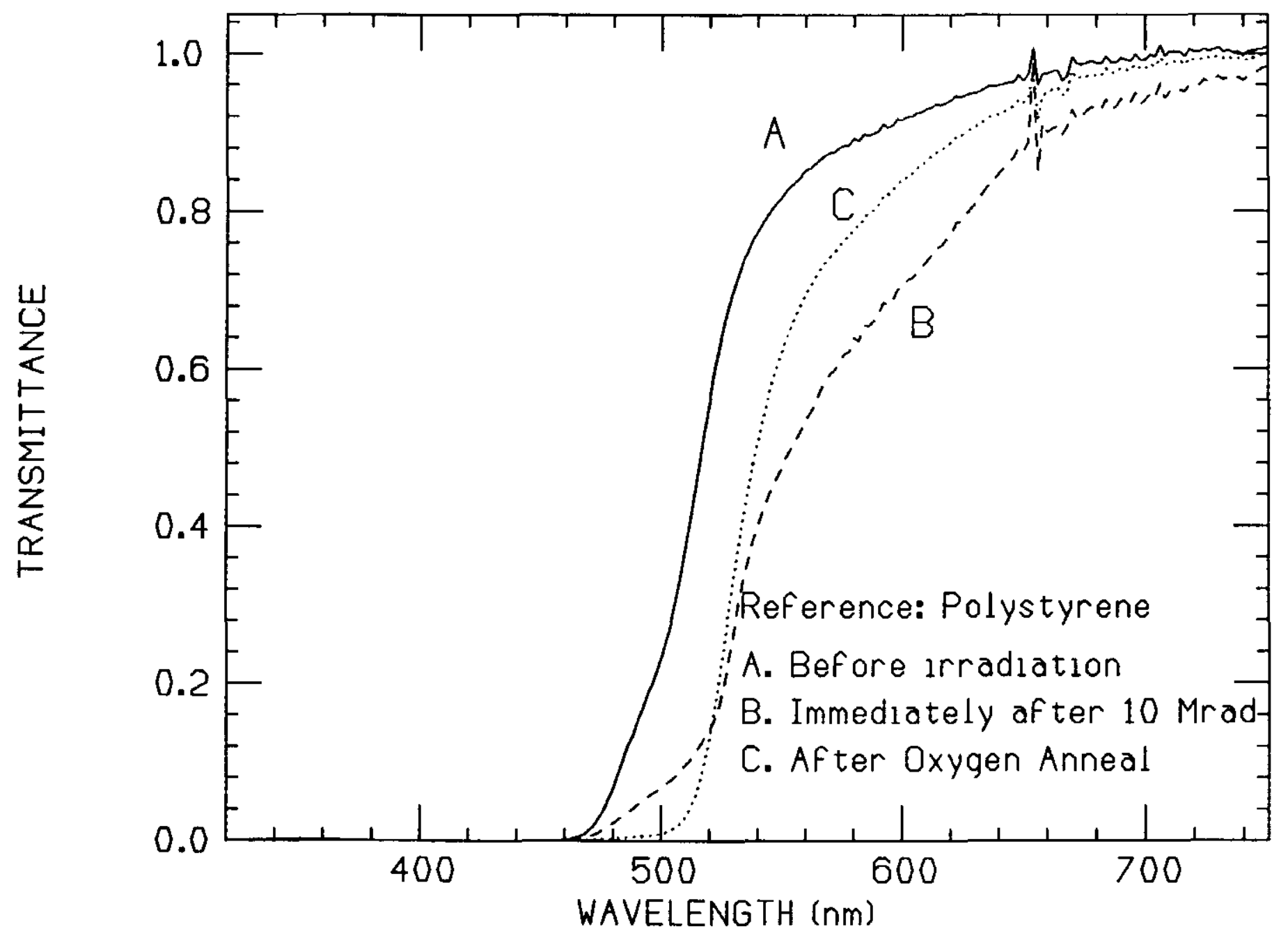


0.02\% ACRIDINE Y -HIGH DOSE RATE IRRADIATION IN AIR

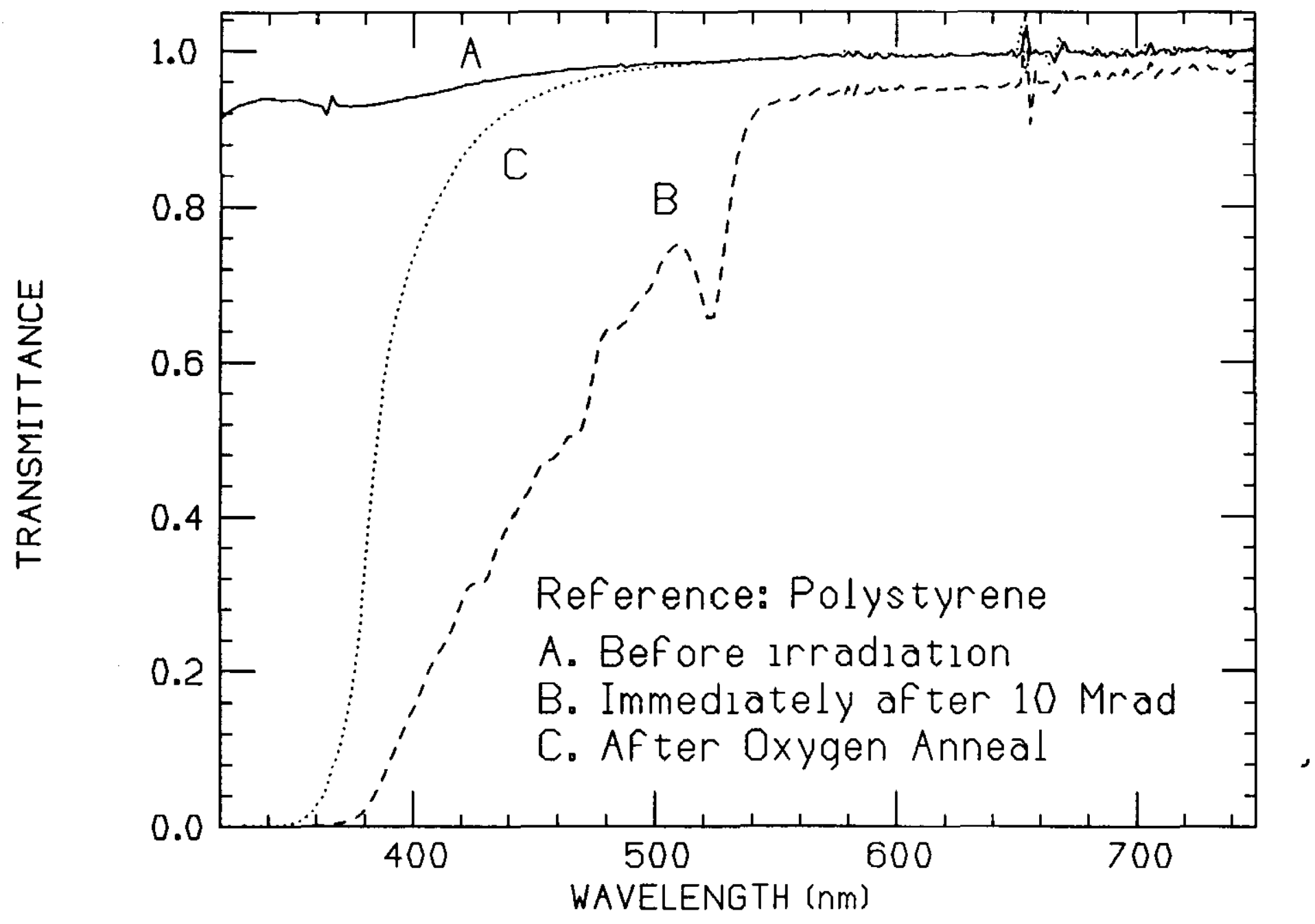


0.02\% ACRIFLAVIN -HIGH DOSE RATE IRRADIATION IN AIR

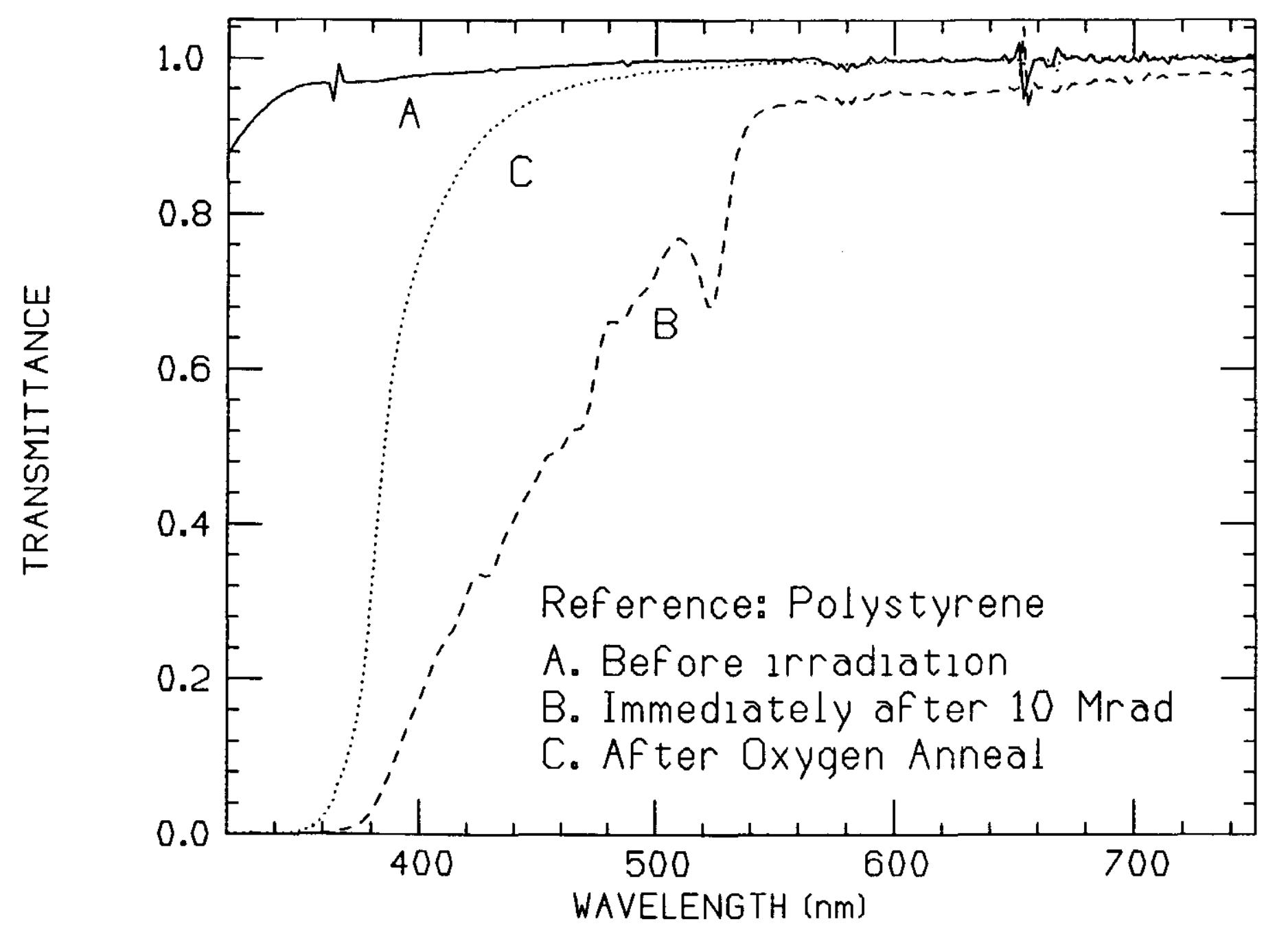




\subsection{2\% BBOT - HIGH DOSE RATE IRRADIATION IN AIR}

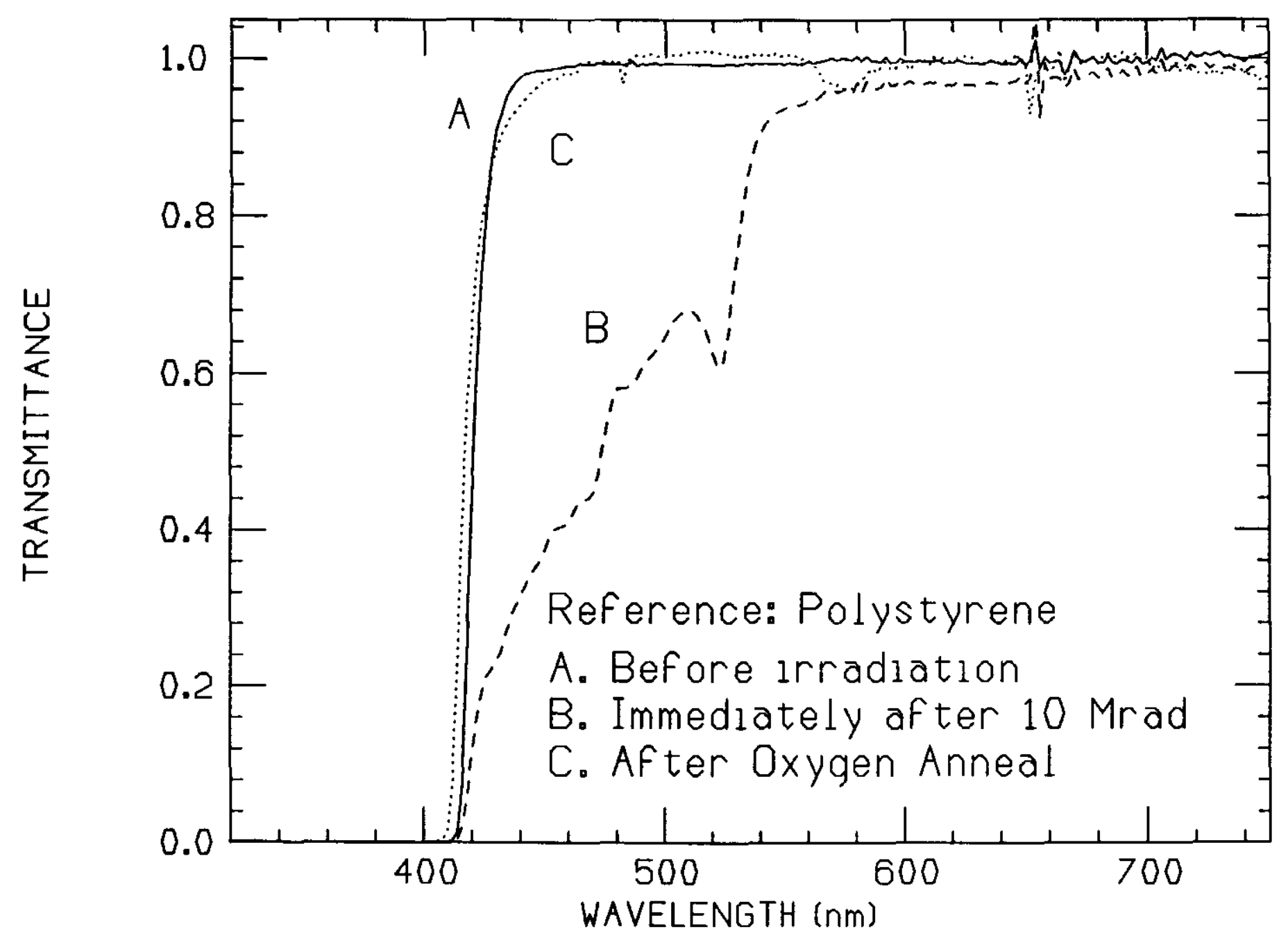


0.02\% bIS-MSB - HIGH DOSE RATE IRRADIATION IN AIR

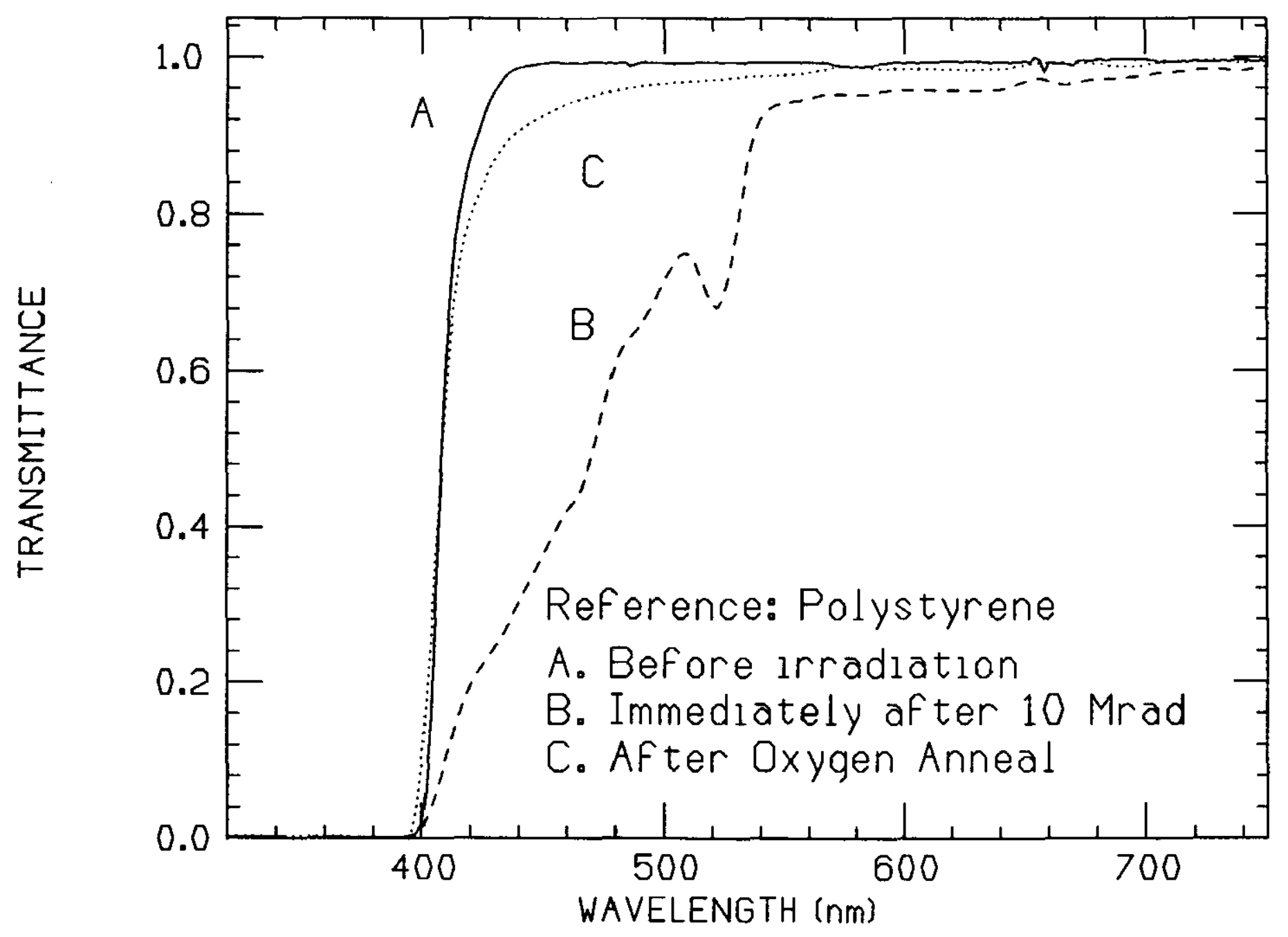


0.02\% BSFL - HIGH DOSE RATE IRRADIATION IN AIR

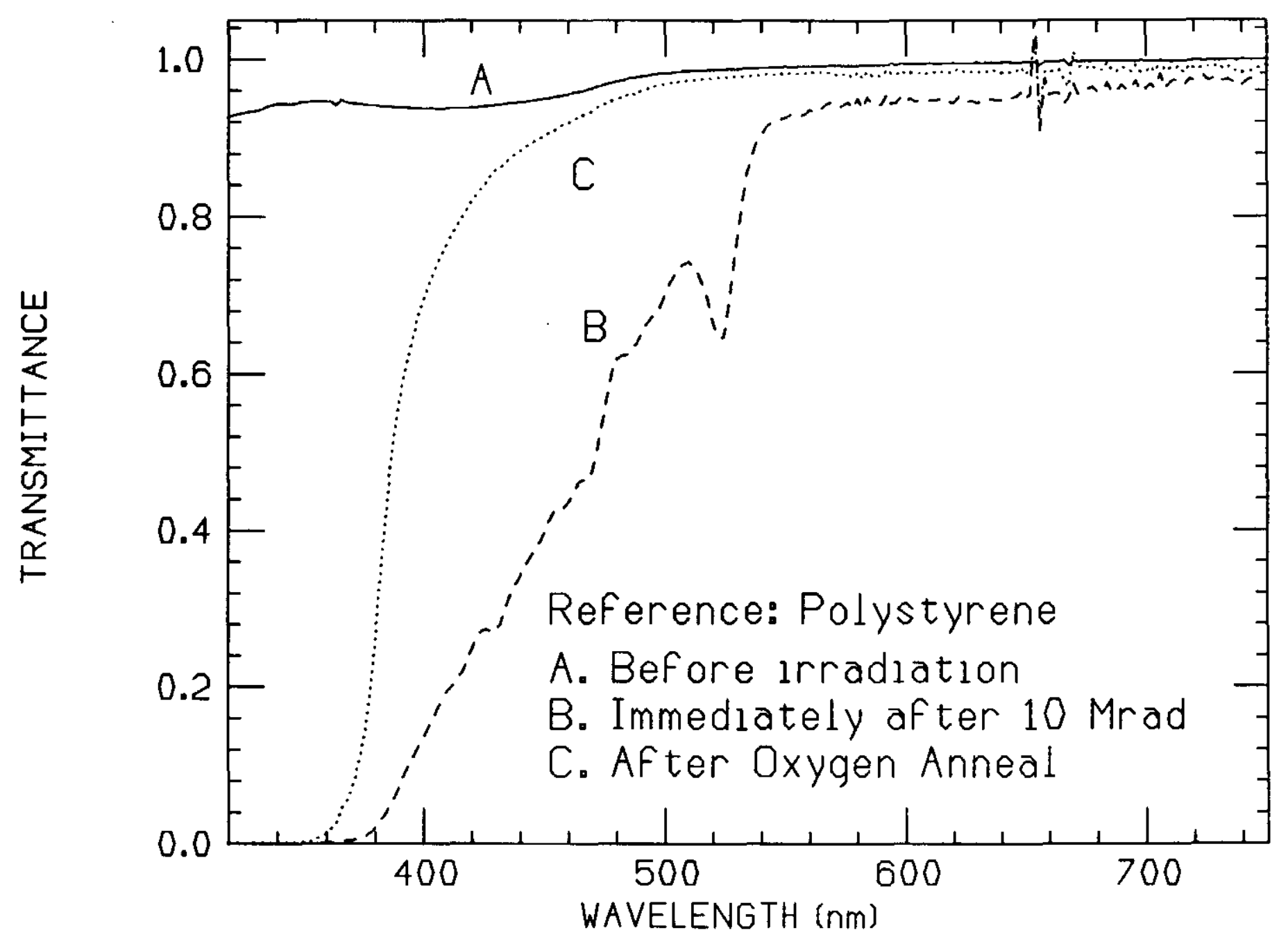


0.02\% CARBOSTYRIL3 -HIGH DOSE RATE IRRADIATION IN AIR

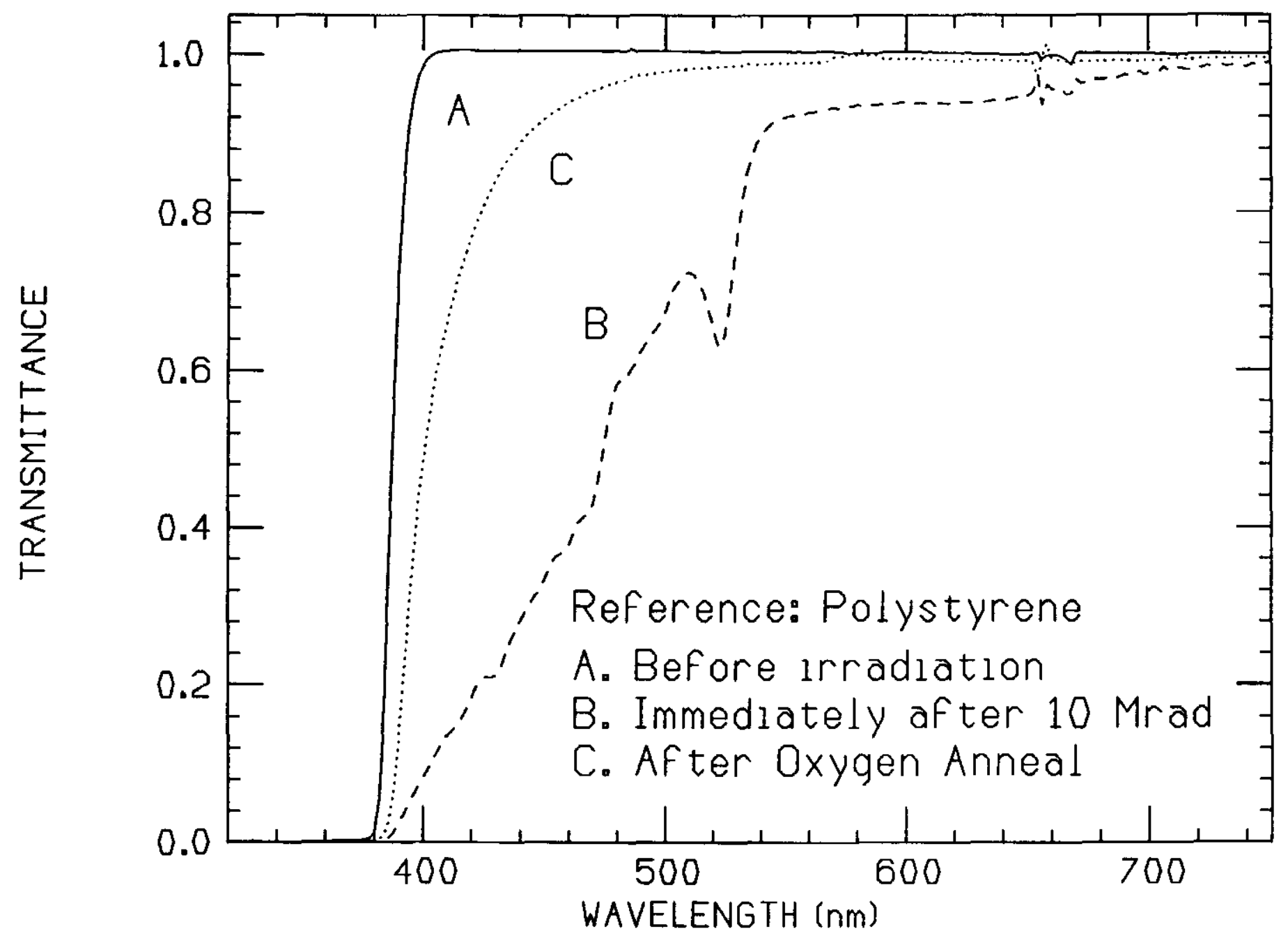


0.02\% CBSTY 124 - HIGH DOSE RATE IRRADIATION IN AIR

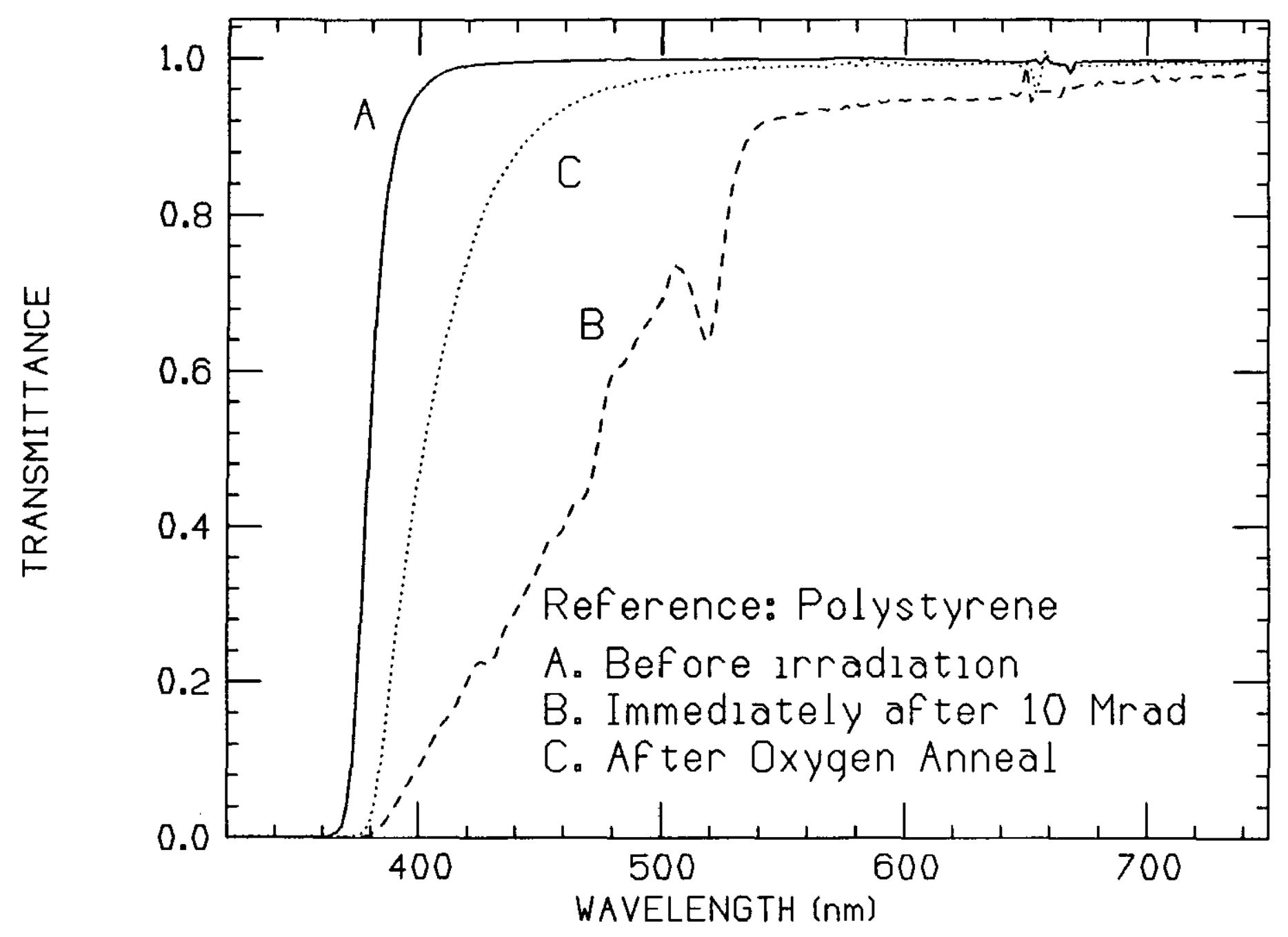


0.01\% DCM/DCM2 - HIGH DOSE RATE IRRADIATION IN AIR

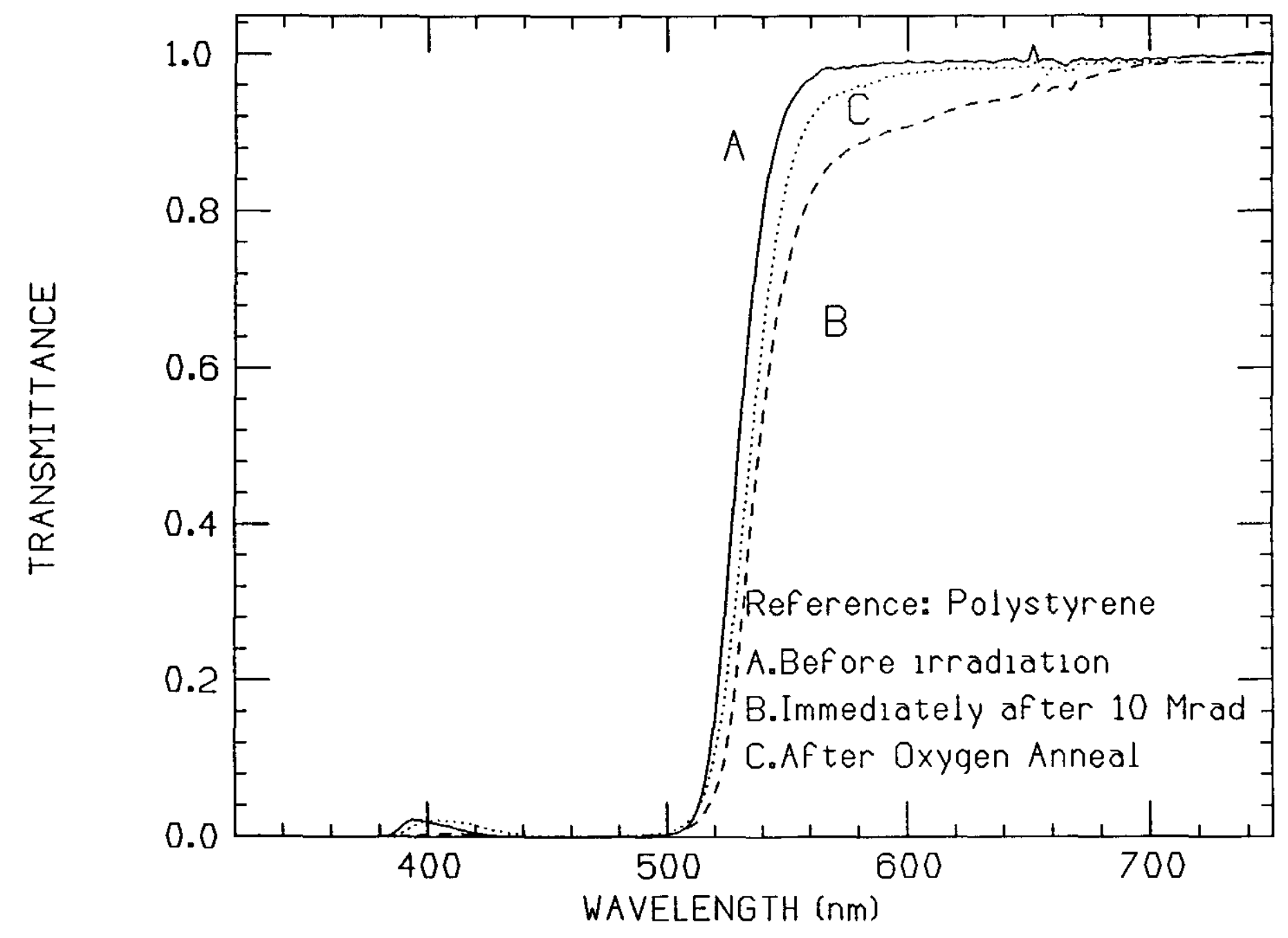


0.02\% DCM/DCM2 - HIGH DOSE RATE IRRADIATION IN AIR

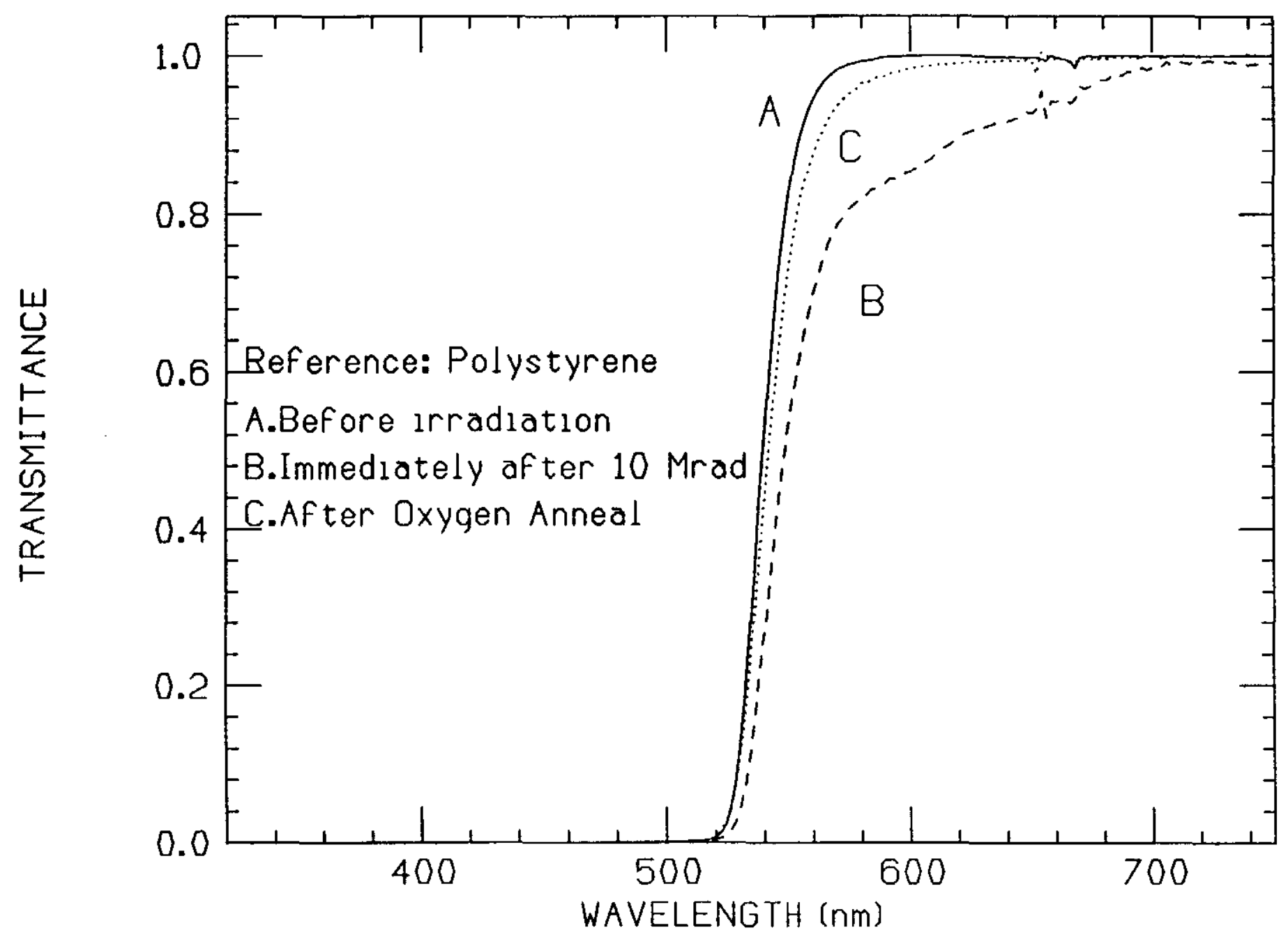


0.02\% DIACFN - HIGH DOSE RATE IRRADIATION IN AIR

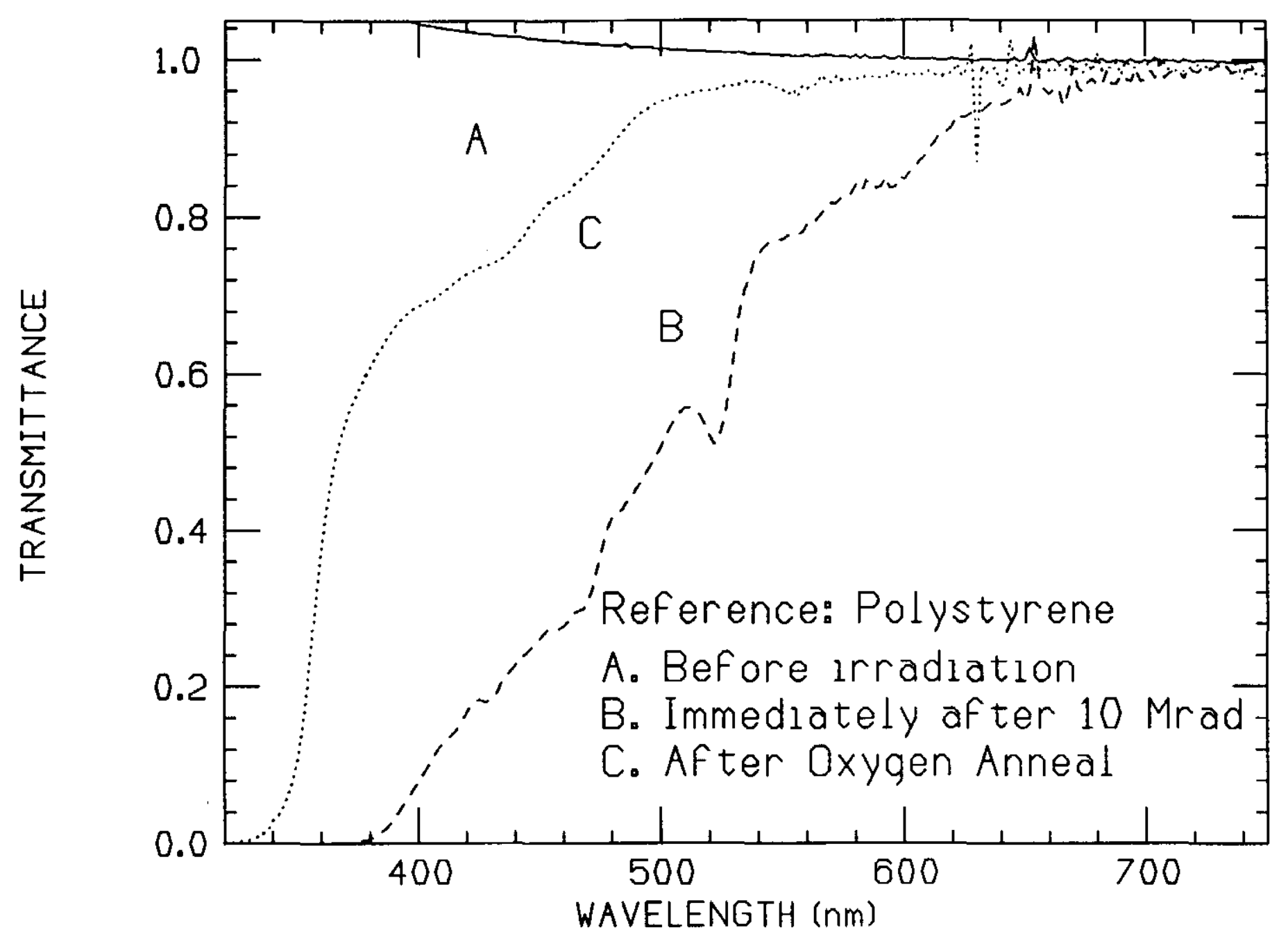




\subsection{2\% DIBRFN - HIGH DOSE RATE IRRADIATION IN AIR}

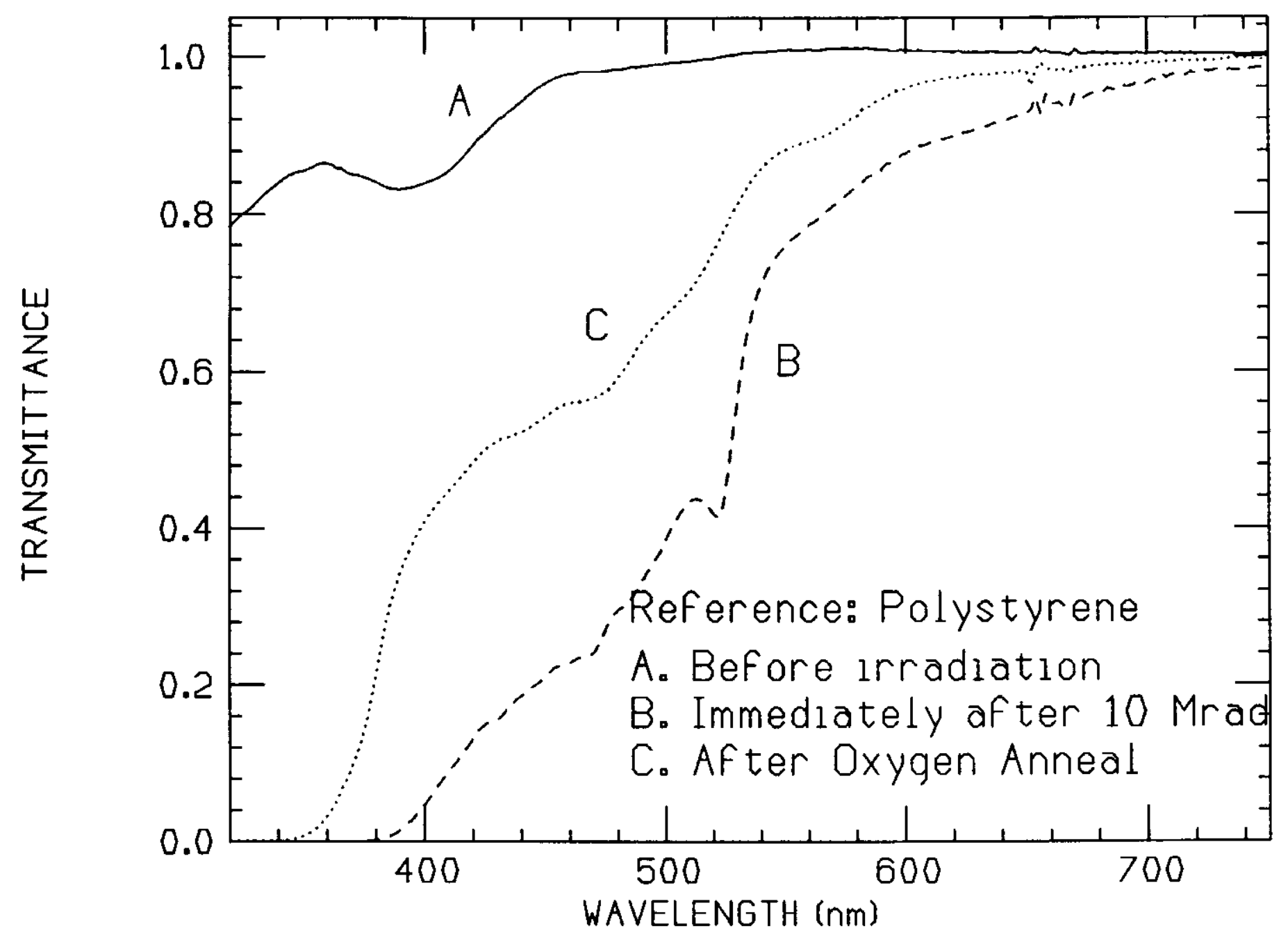


0.02\% DICLFN/FN548-HIGH DOSE RATE IRRADIATION IN AIR

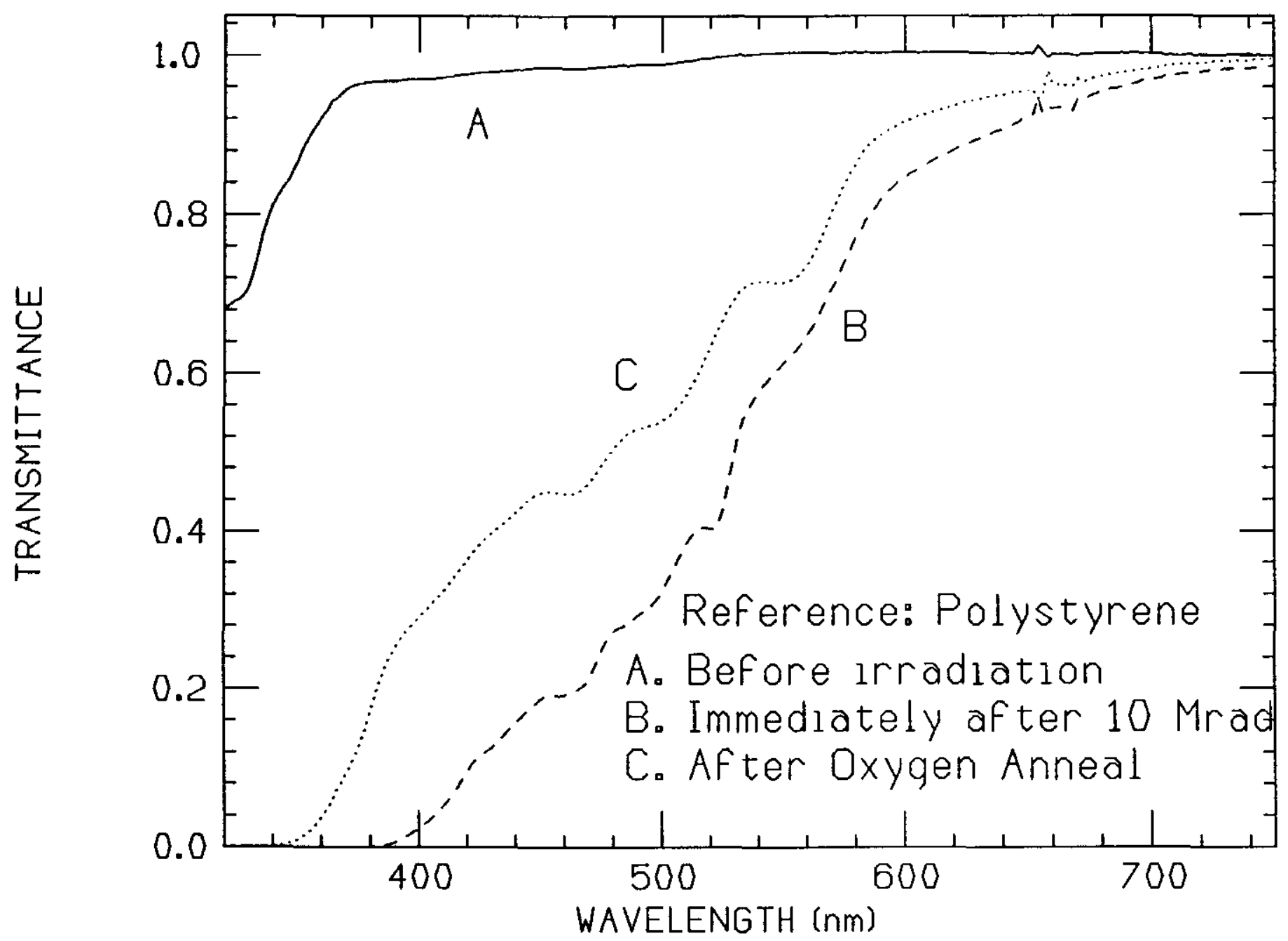




\subsection{2\% DMETCI - HIGH DOSE RATE IRRADIATION IN AIR}

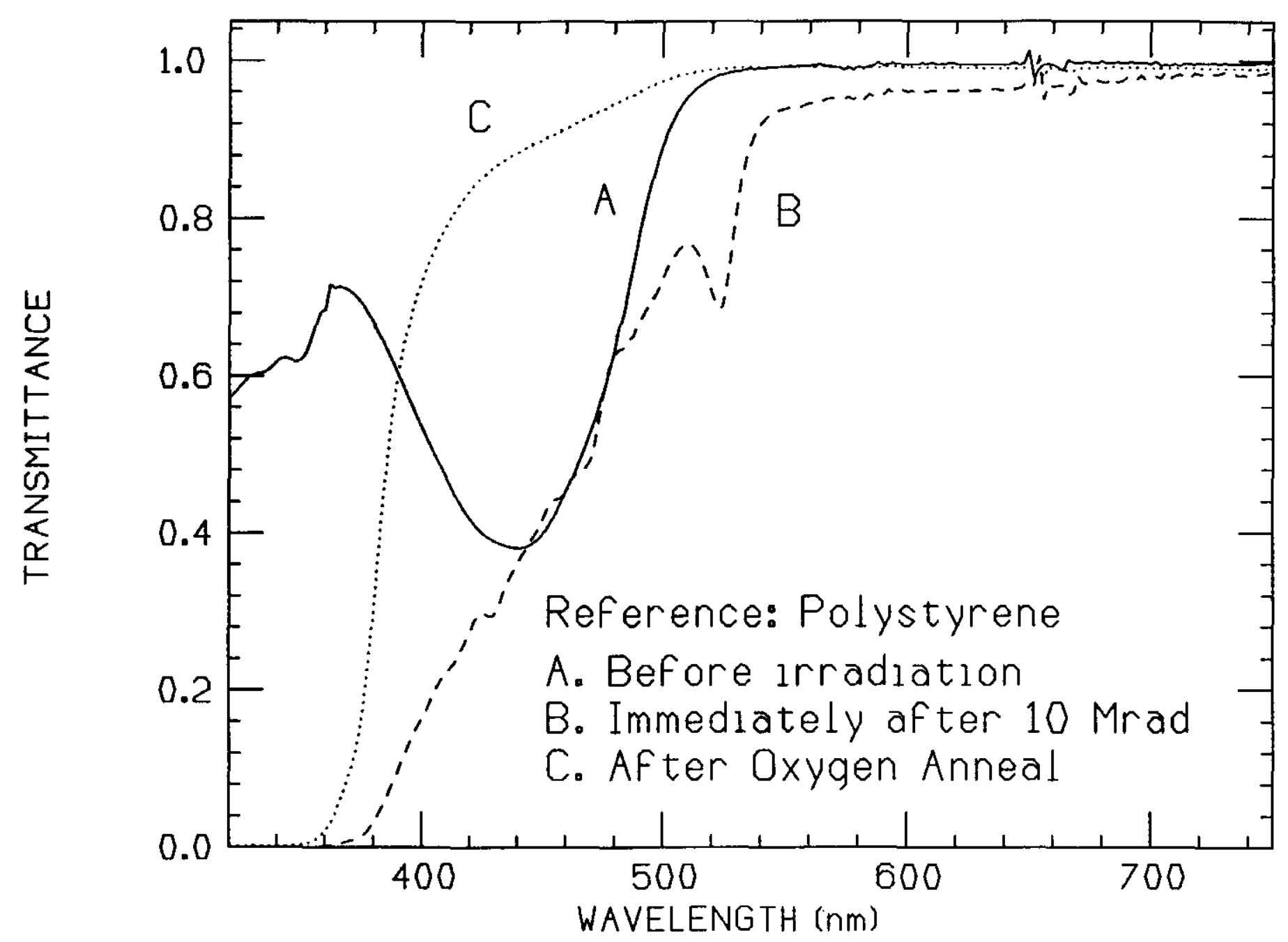


0.02\% DMPOPOP - HIGH DOSE RATE IRRADIATION IN AIR

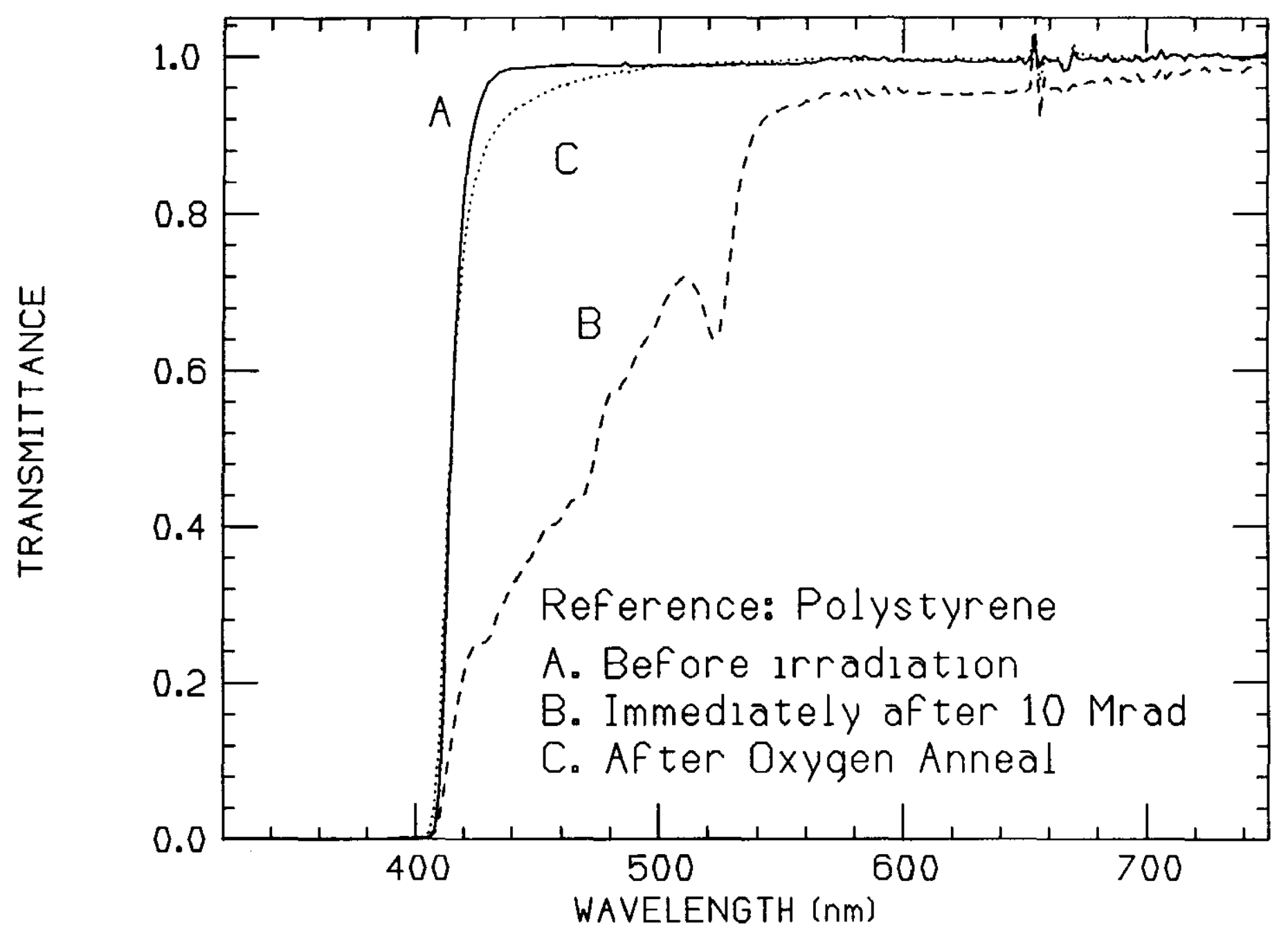


$0.02 \%$ DOCI - HIGH DOSE RATE IRRADIATION IN AIR

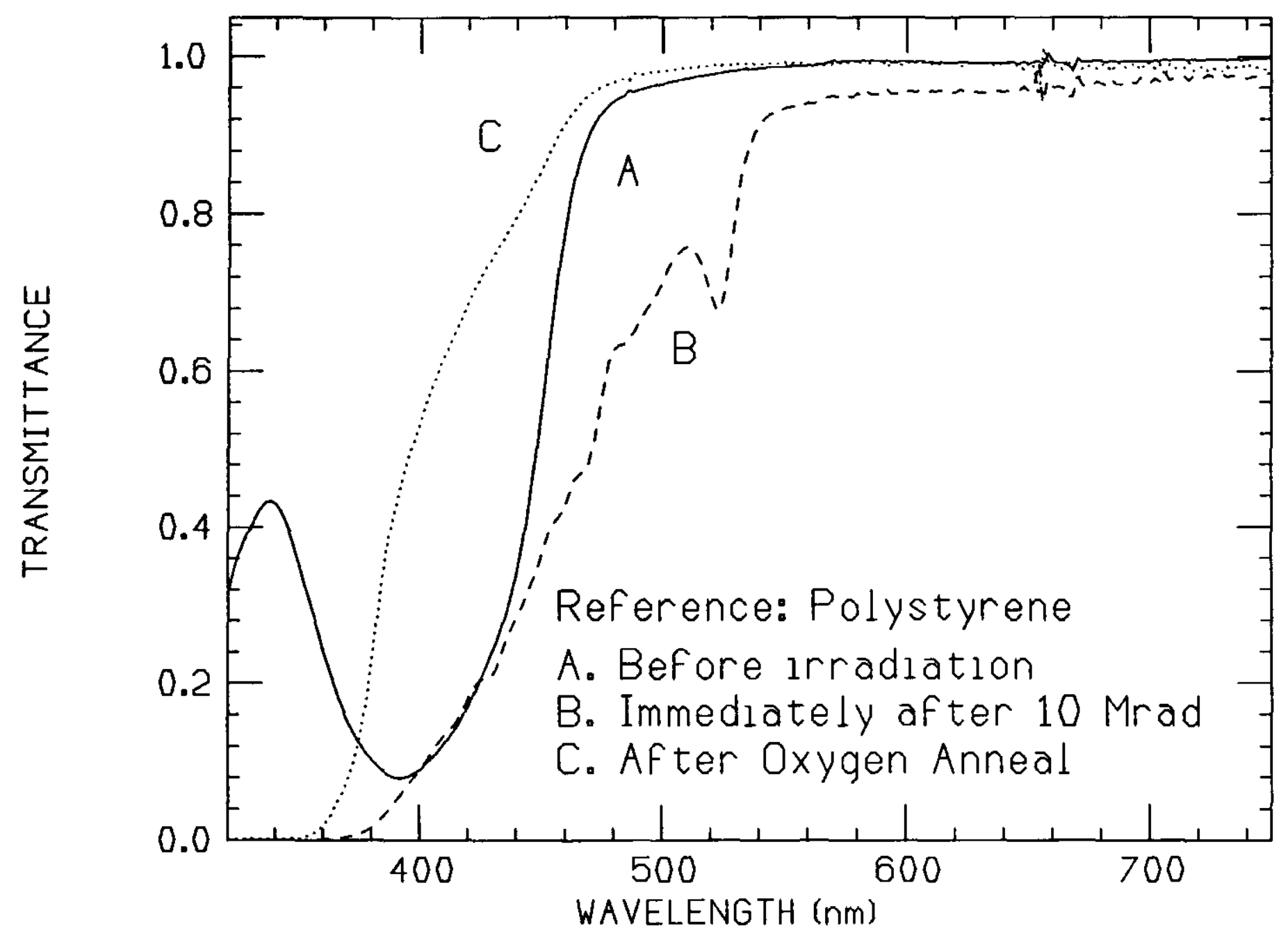


0.02\% DODCI - HIGH DOSE RATE IRRADIATION IN AIR

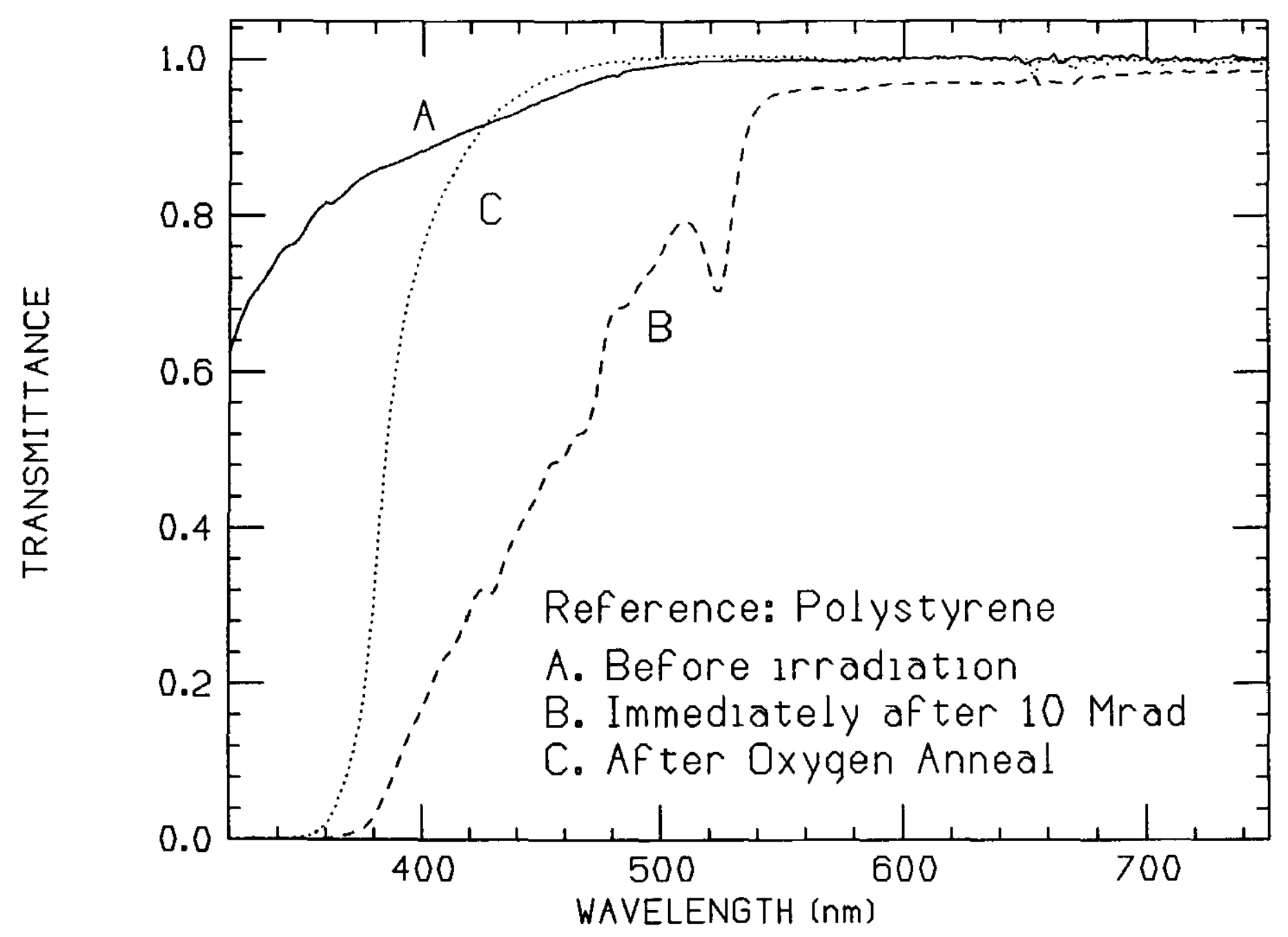


0.01\% DODCI+C-E - HIGH DOSE RATE IRRADIATION IN AIR

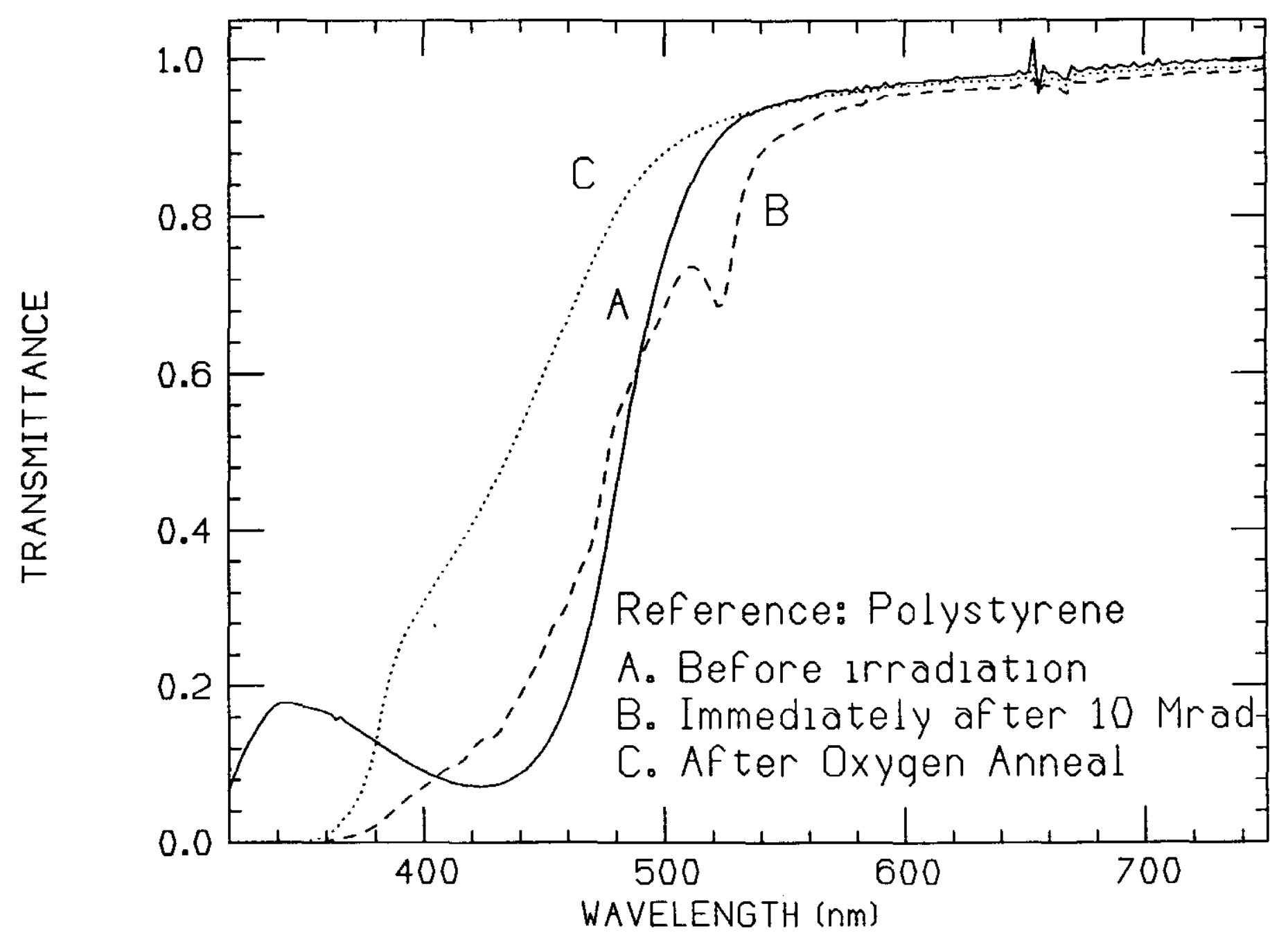




\subsection{2\% DQOCI - HIGH DOSE RATE IRRADIATION IN AIR}

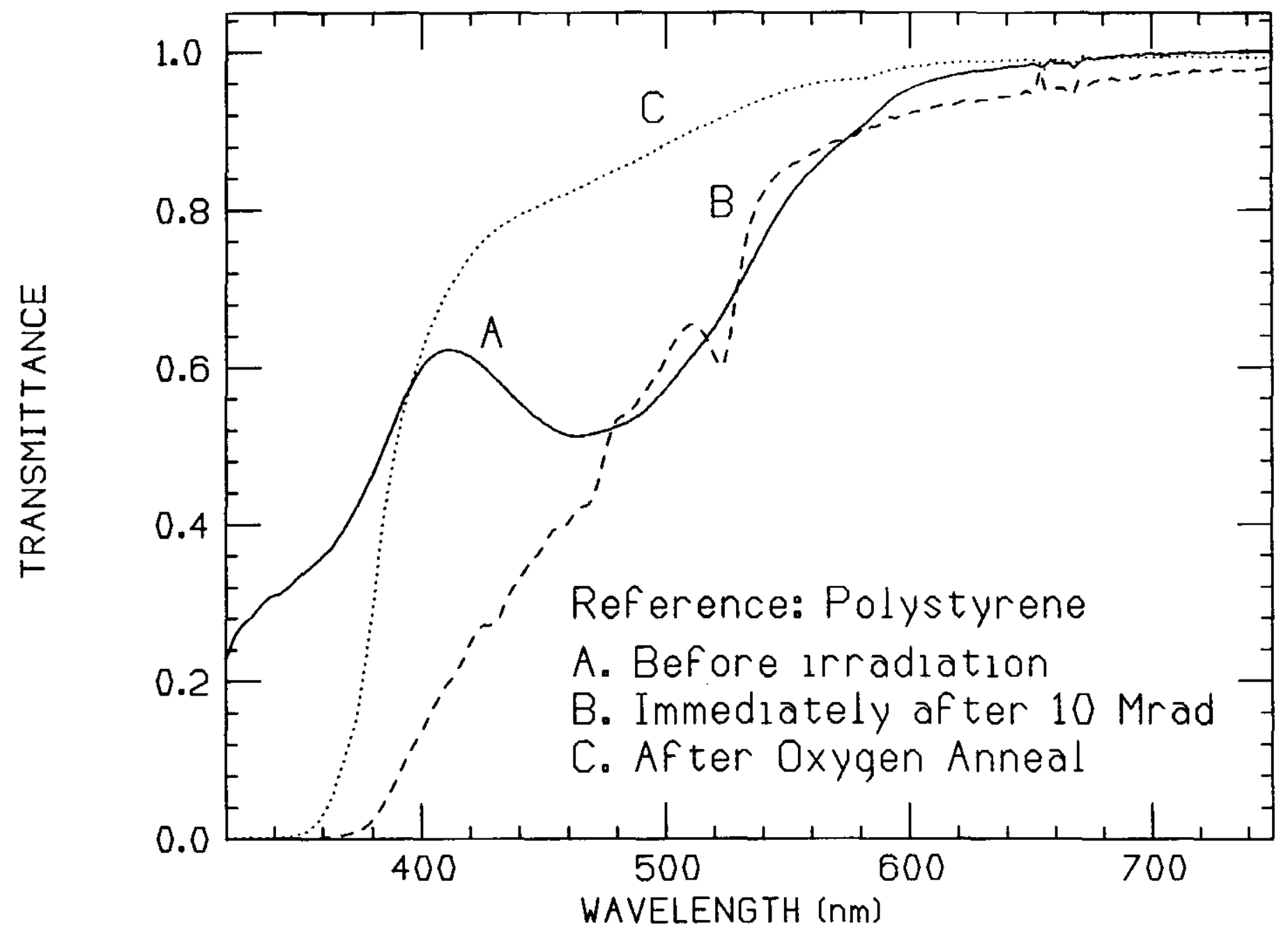


0.02\% DTCI - HIGH DOSE RATE IRRADIATION IN AIR

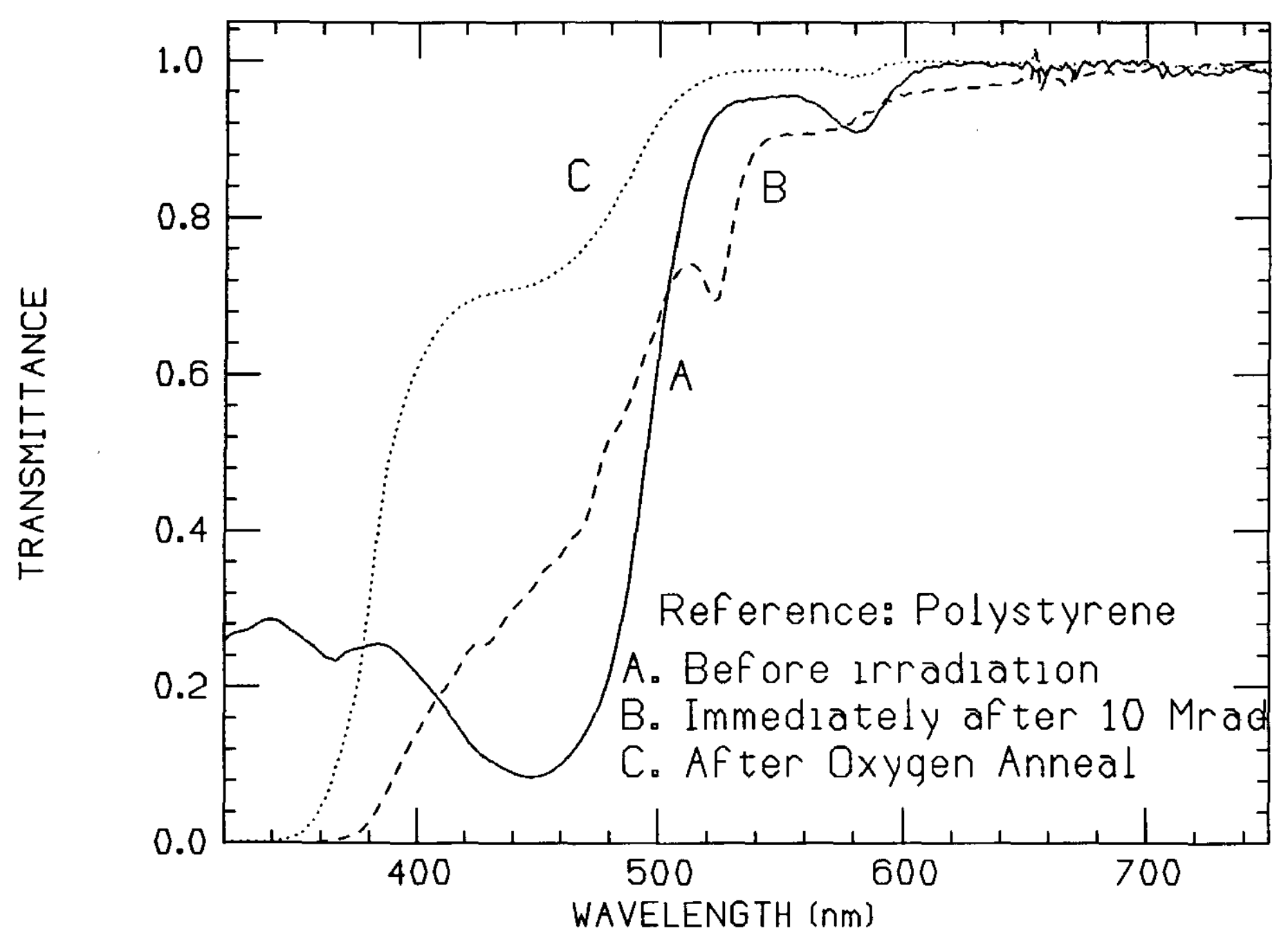




\subsection{1\% DTDCI - HIGH DOSE RATE IRRADIATION IN AIR}

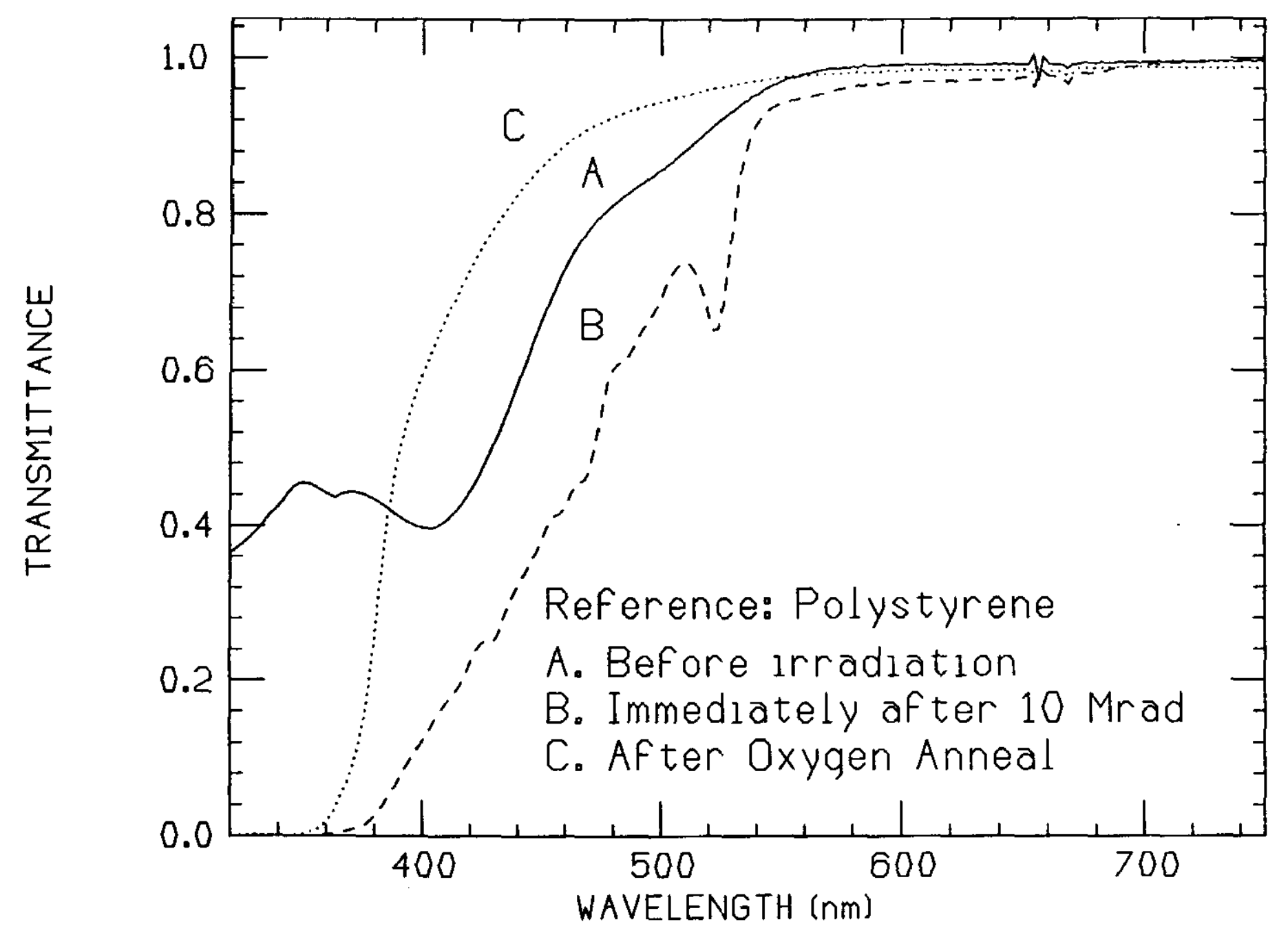


$0.01 \%$ HIDCI+C-E - HIGH DOSE RATE IRRADIATION IN AIR

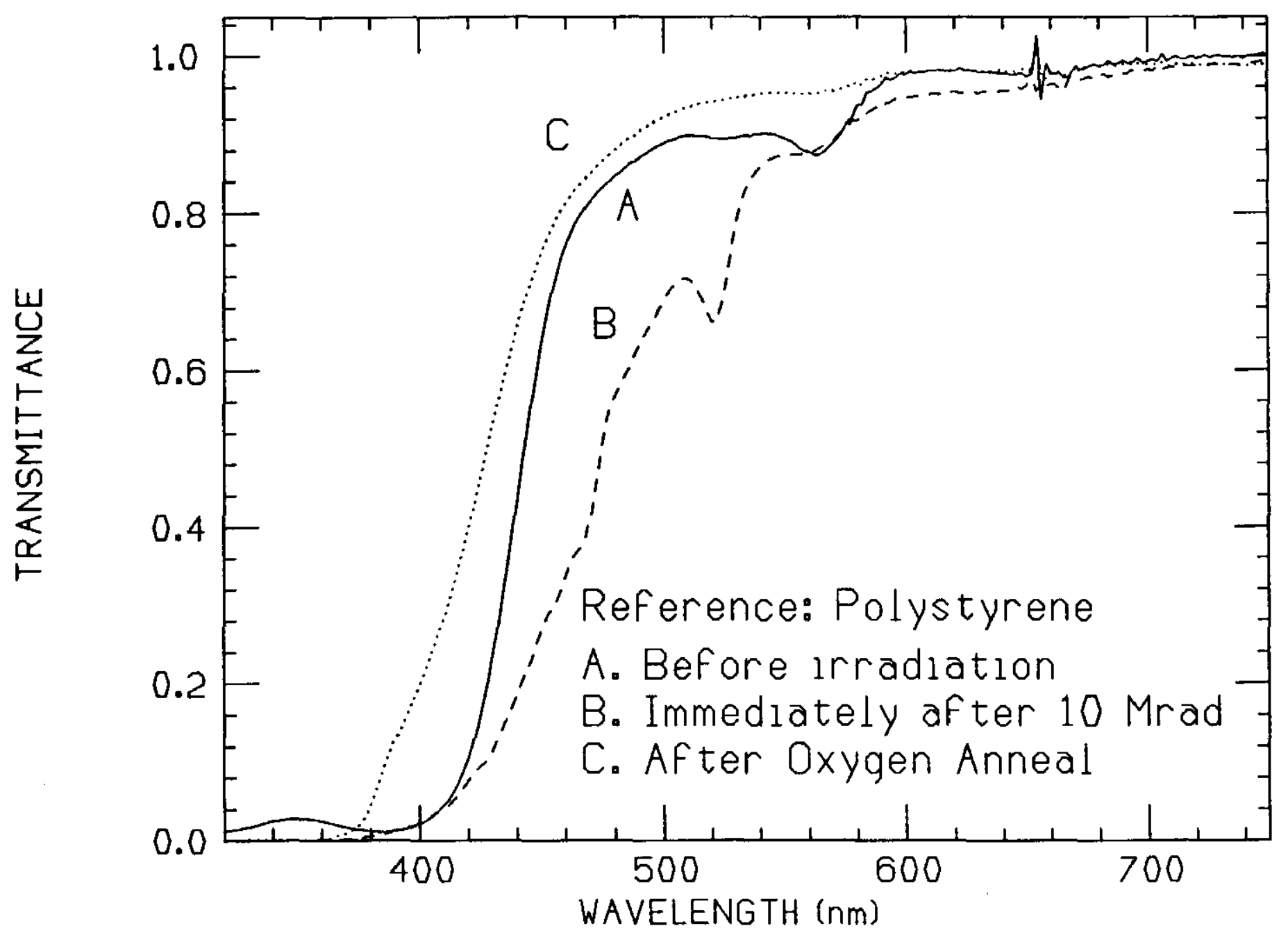




\subsection{2\% ISCNFN - HIGH DOSE RATE IRRADIATION IN AIR}

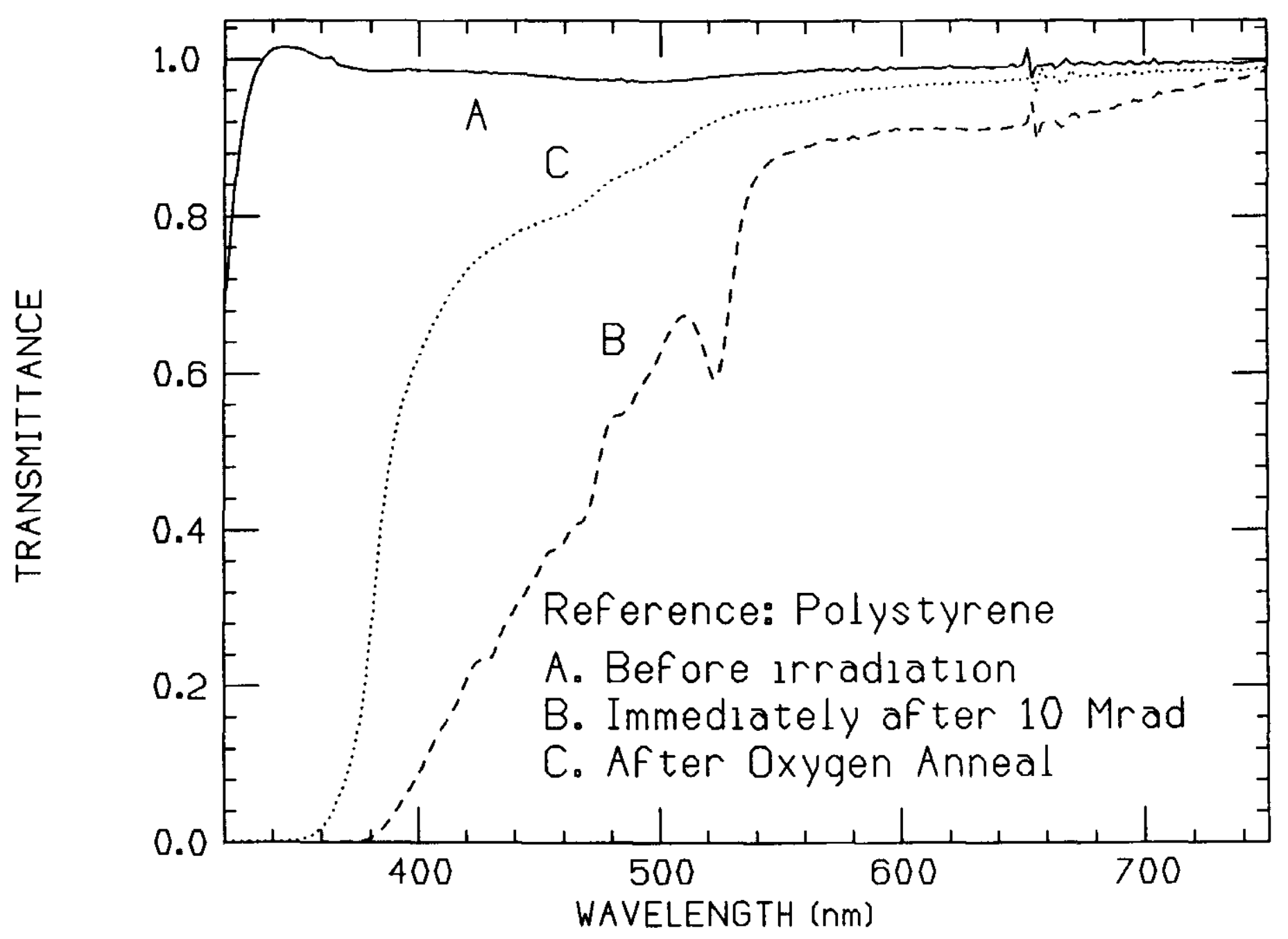


0.02\% KITON RED - HIGH DOSE RATE IRRADIATION IN AIR

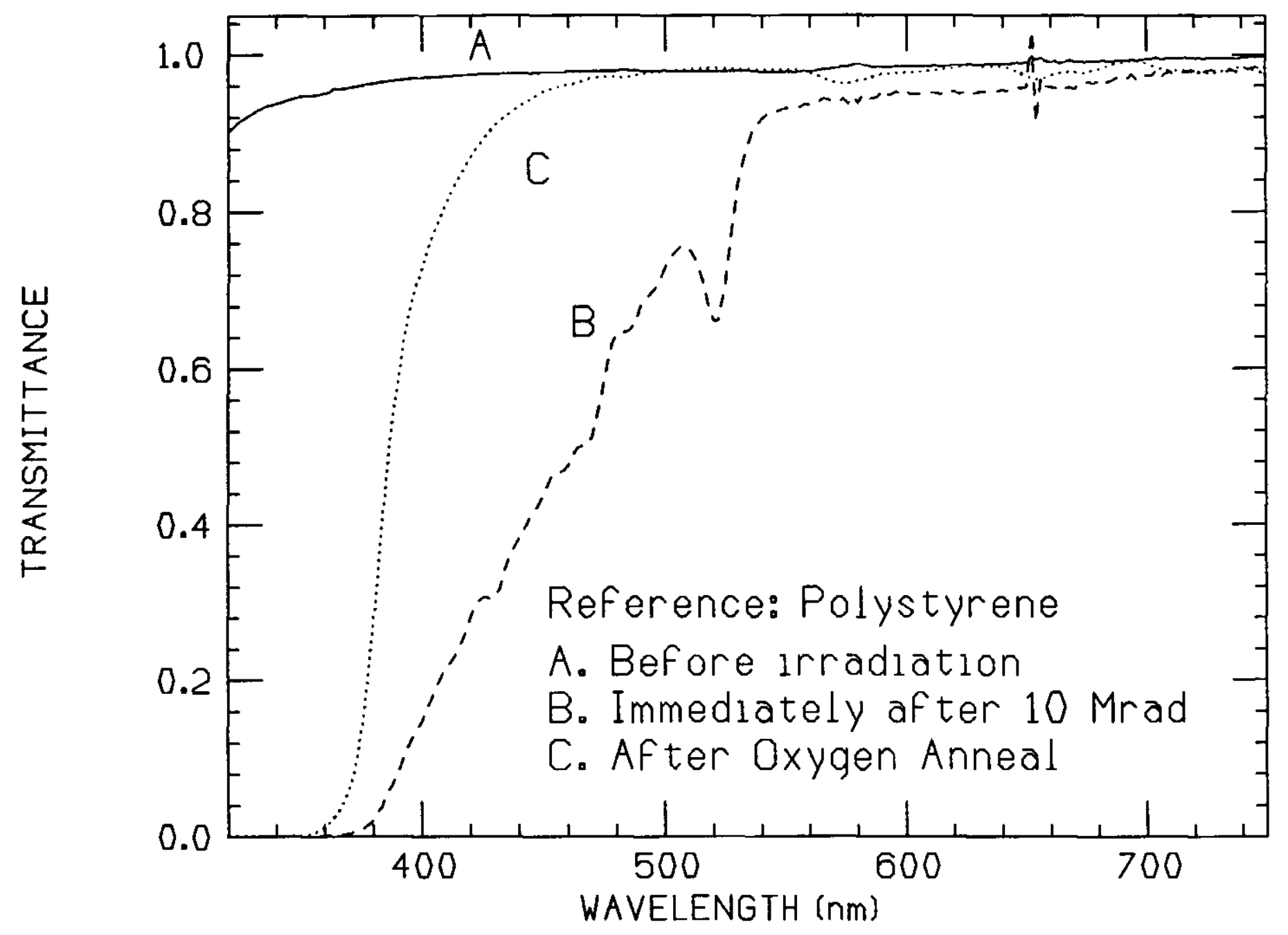




\subsection{2\% LD 490 - HIGH DOSE RATE IRRADIATION IN AIR}

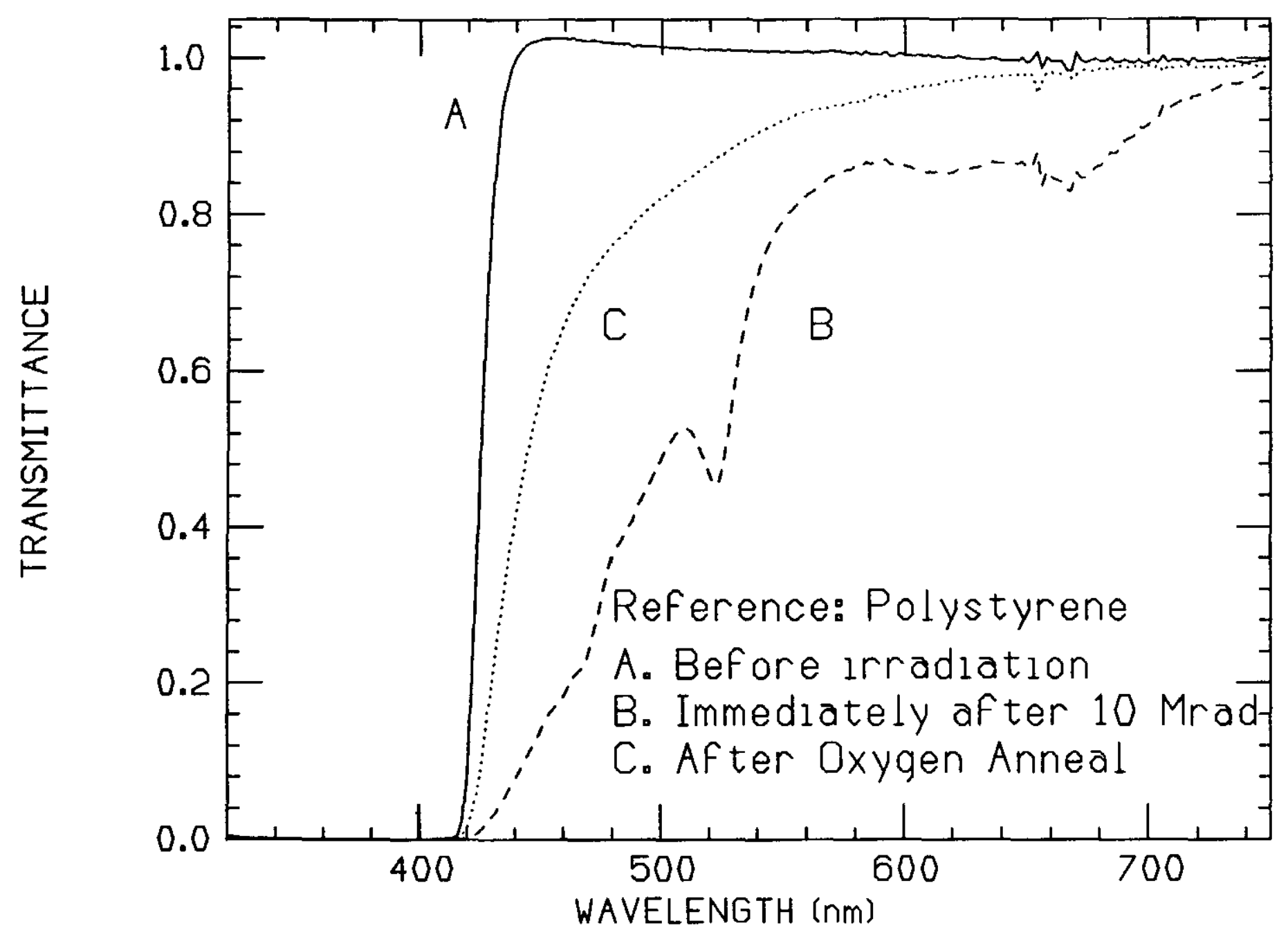




\subsection{2\% LD 688 - HIGH DOSE RATE IRRADIATION IN AIR}

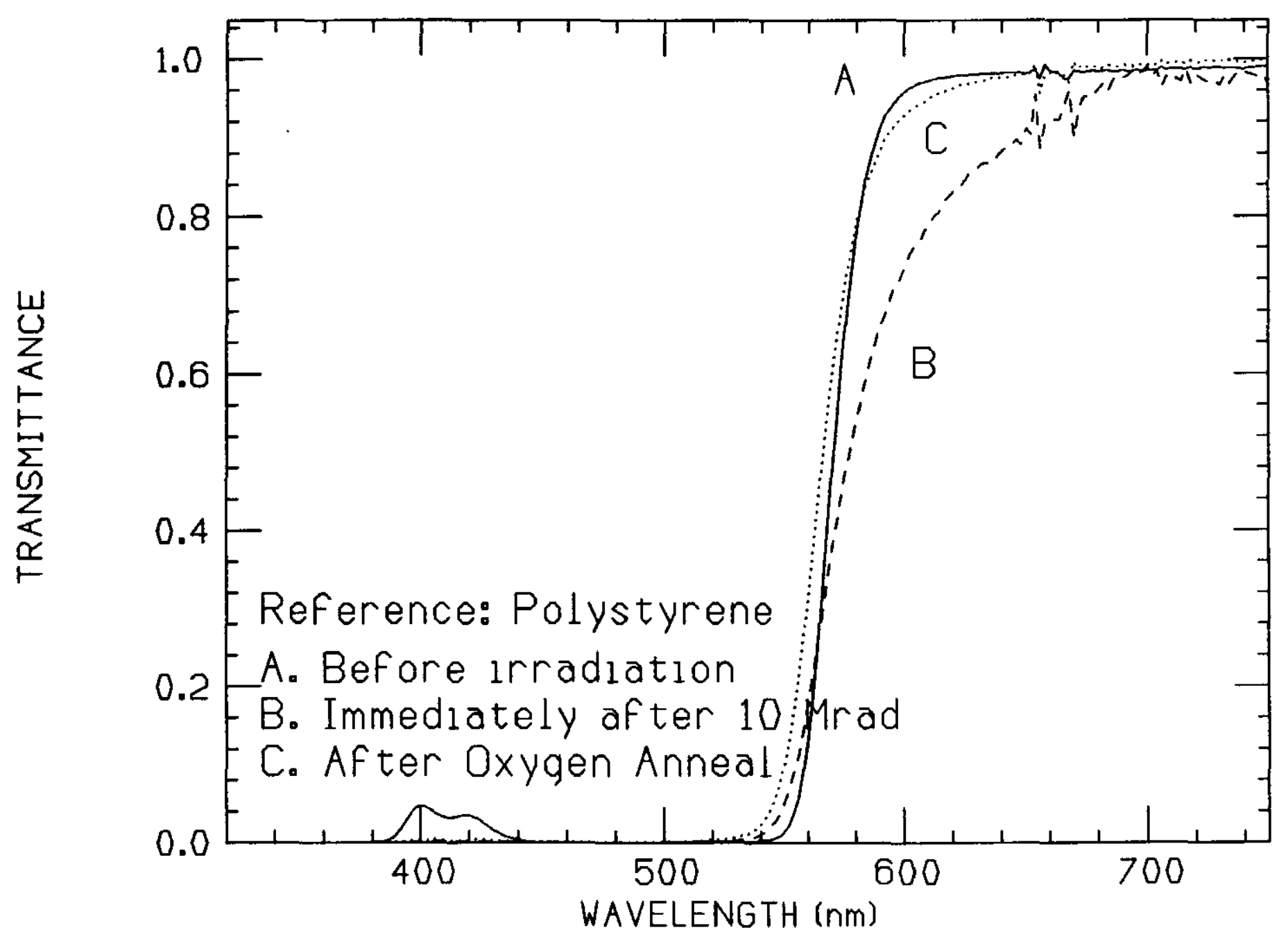


0.01\% LDS 722+C-E - HIGH DOSE RATE IRRADIATION IN AIR

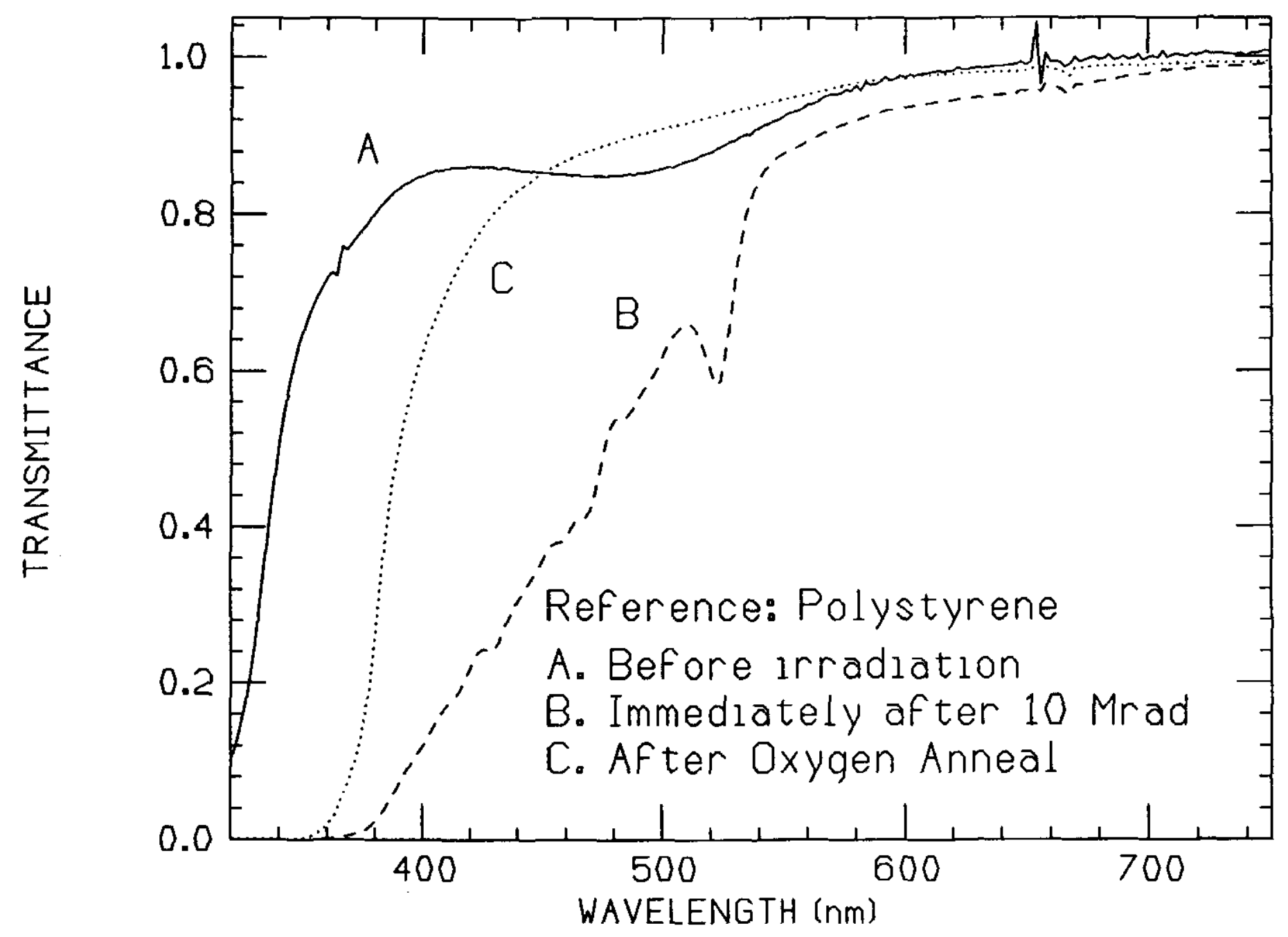


0.01\% LDS $730+C-E$ - HIGH DOSE RATE IRRADIATION IN AIR

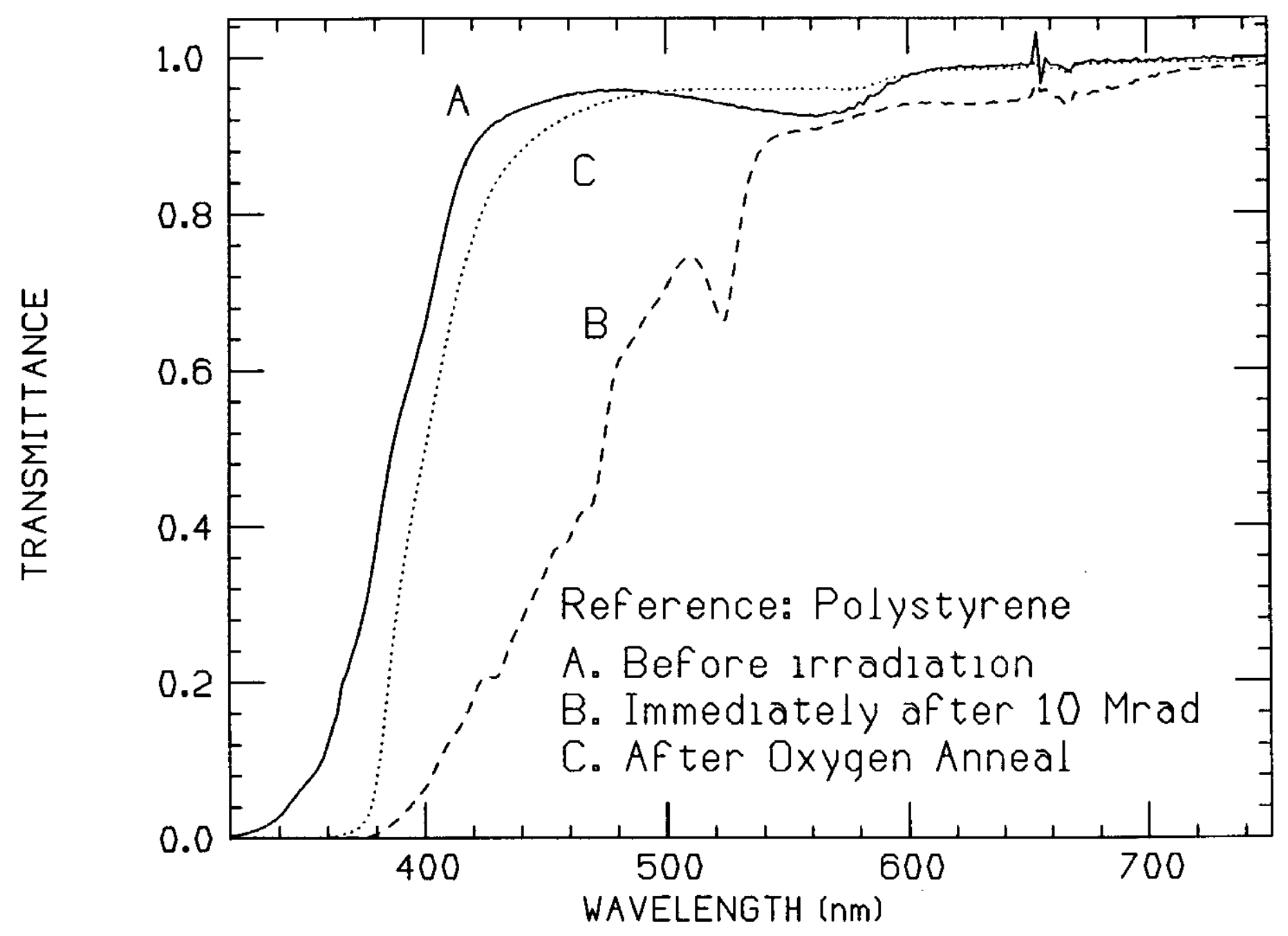


$0.01 \%$ LDS $750+C-E$ - HIGH DOSE RATE IRRADIATION IN AIR

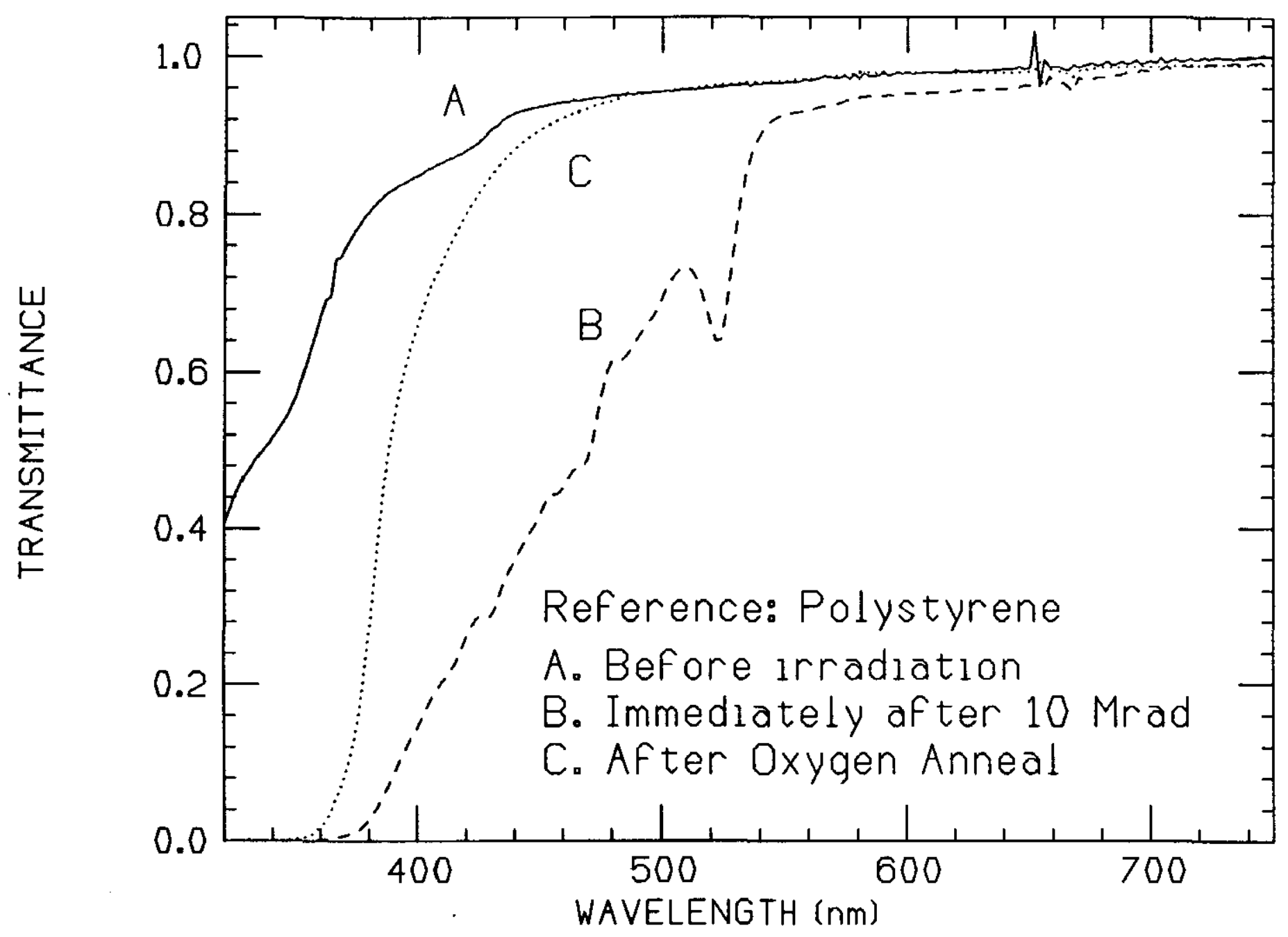


$0.01 \%$ MLCT GR.+C-E -HIGH DOSE RATE IRRADIATION IN AIR

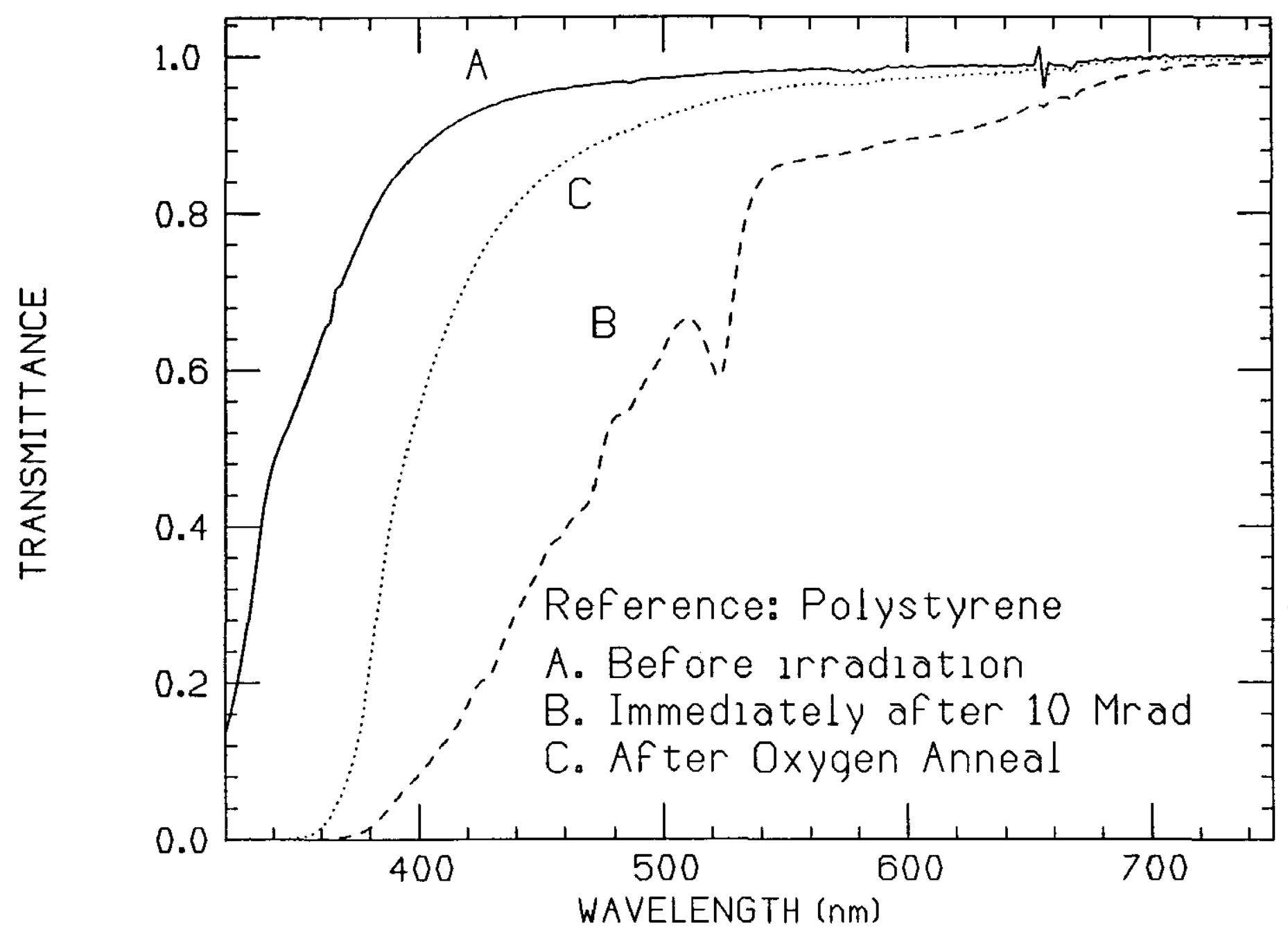


0.01\% NLE B.690+C-E-HIGH DOSE RATE IRRADIATION IN AIR

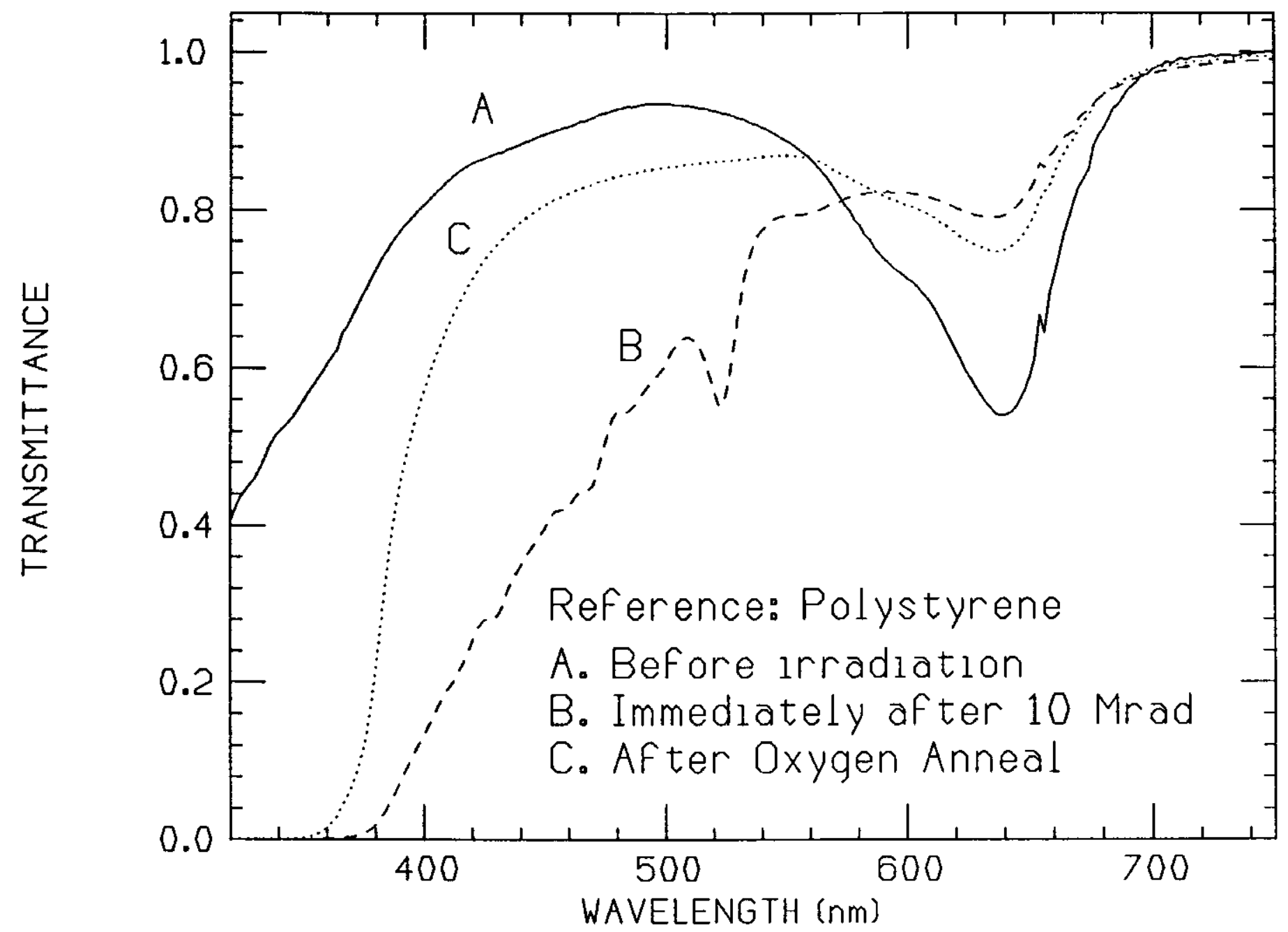




\subsection{1\% OXAZINE 725 - HIGH DOSE RATE IRRADIATION IN AIR}

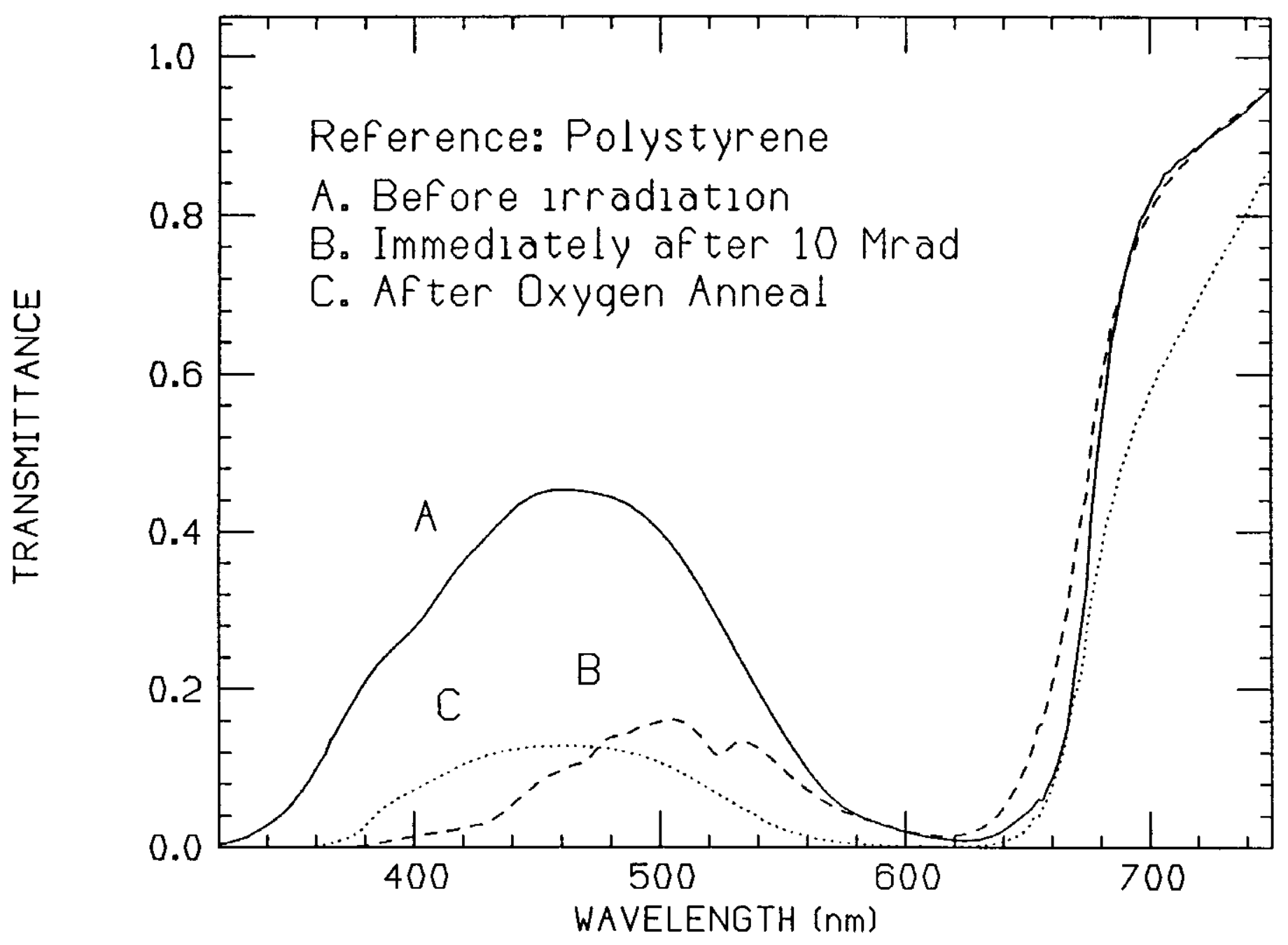


0.02\% PYRIDINE1 - HIGH DOSE RATE IRRADIATION IN AIR

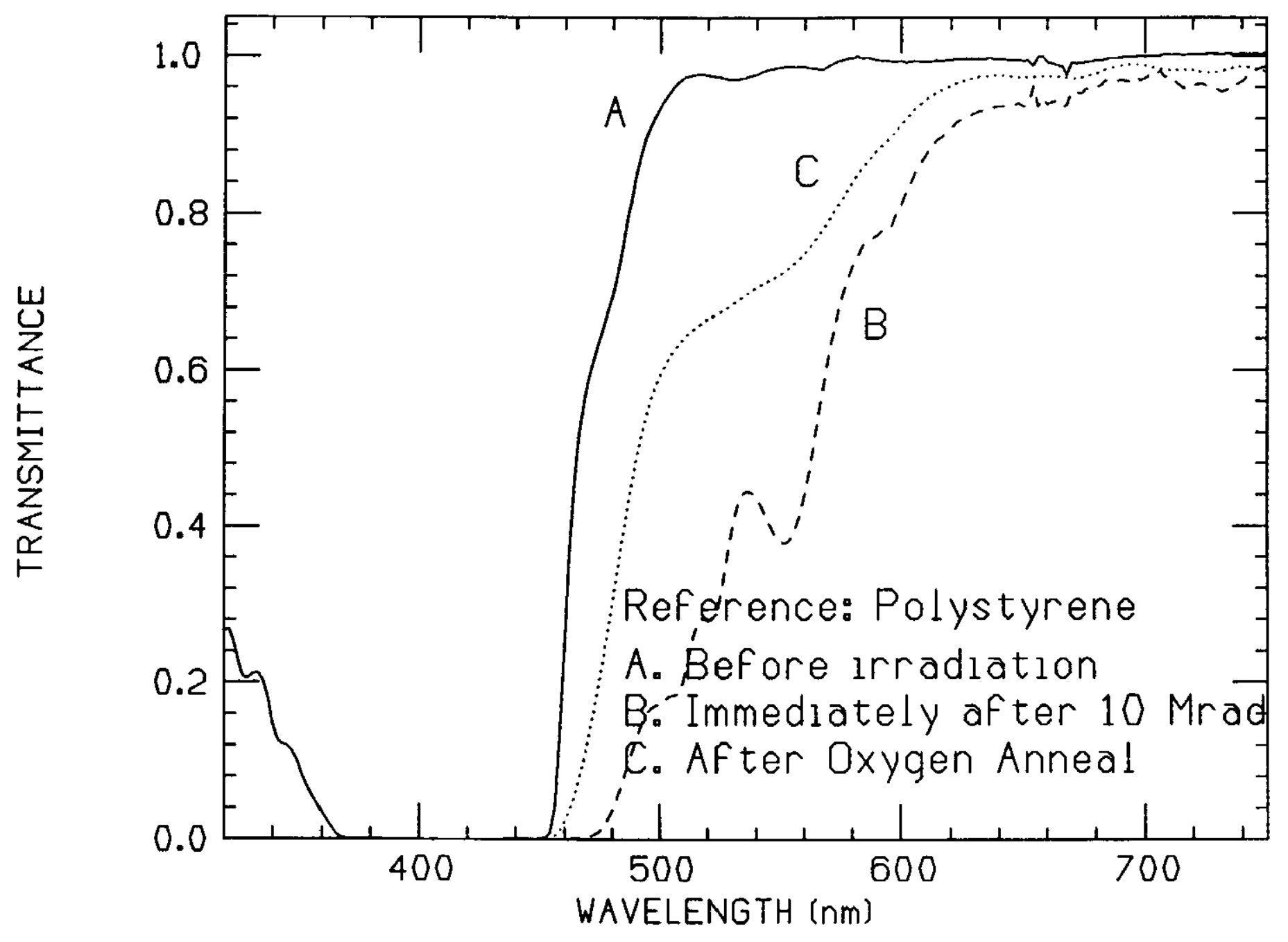


0.02\% RHODAMINE6G - HIGH DOSE RATE IRRADIATION IN AIR

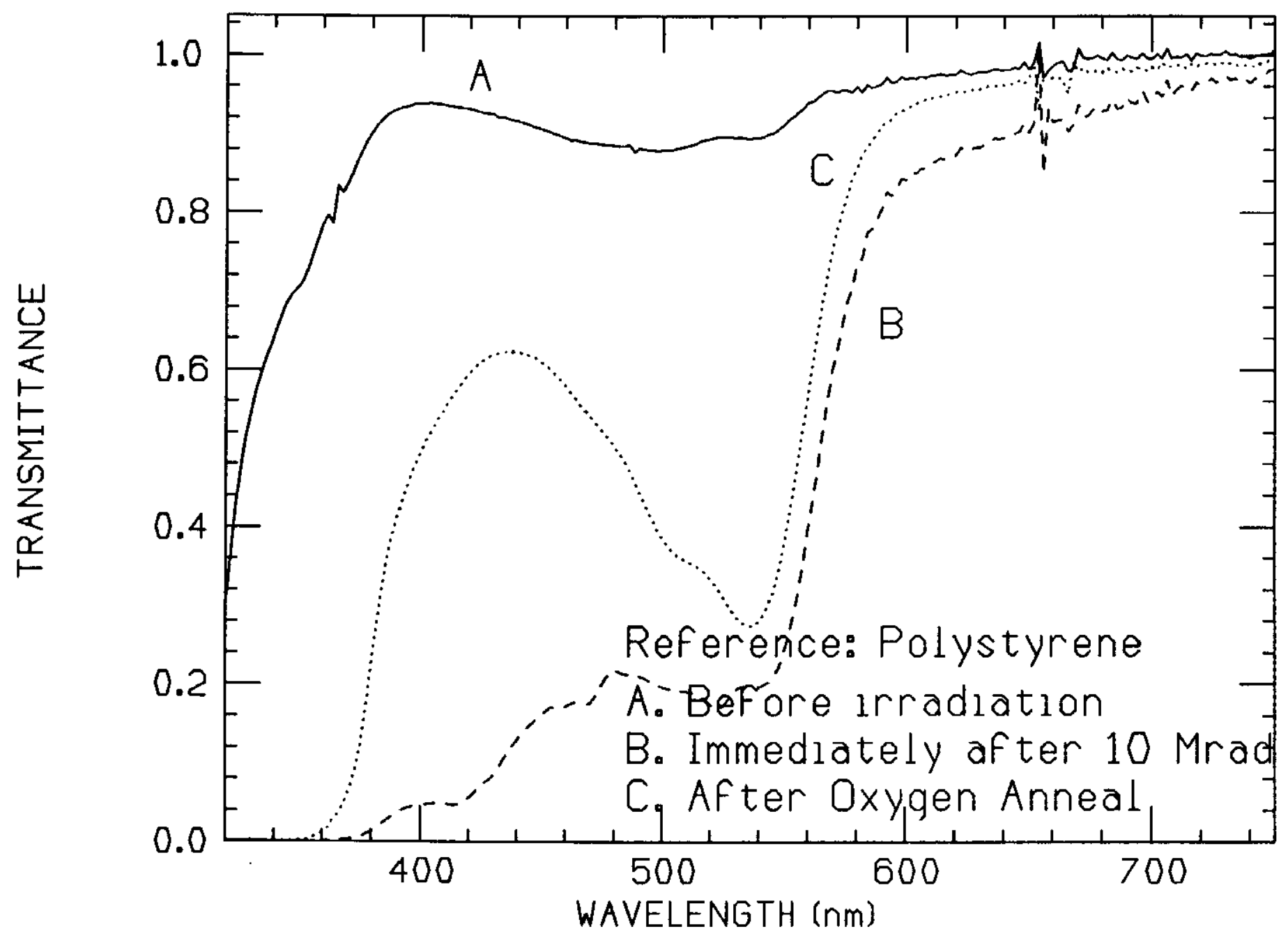




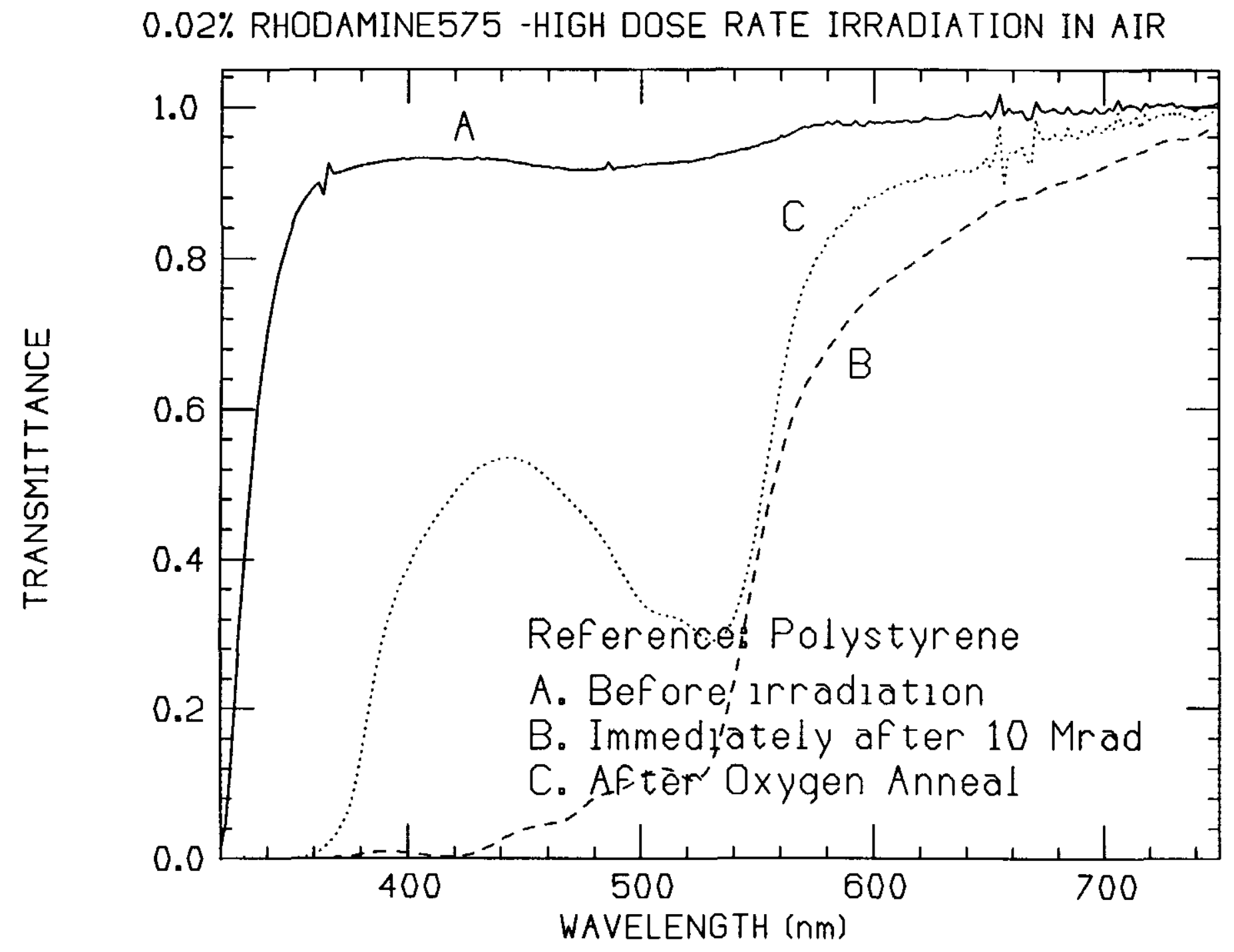


0.02\% STILBENE 420-HIGH DOSE RATE IRRADIATION IN AIR

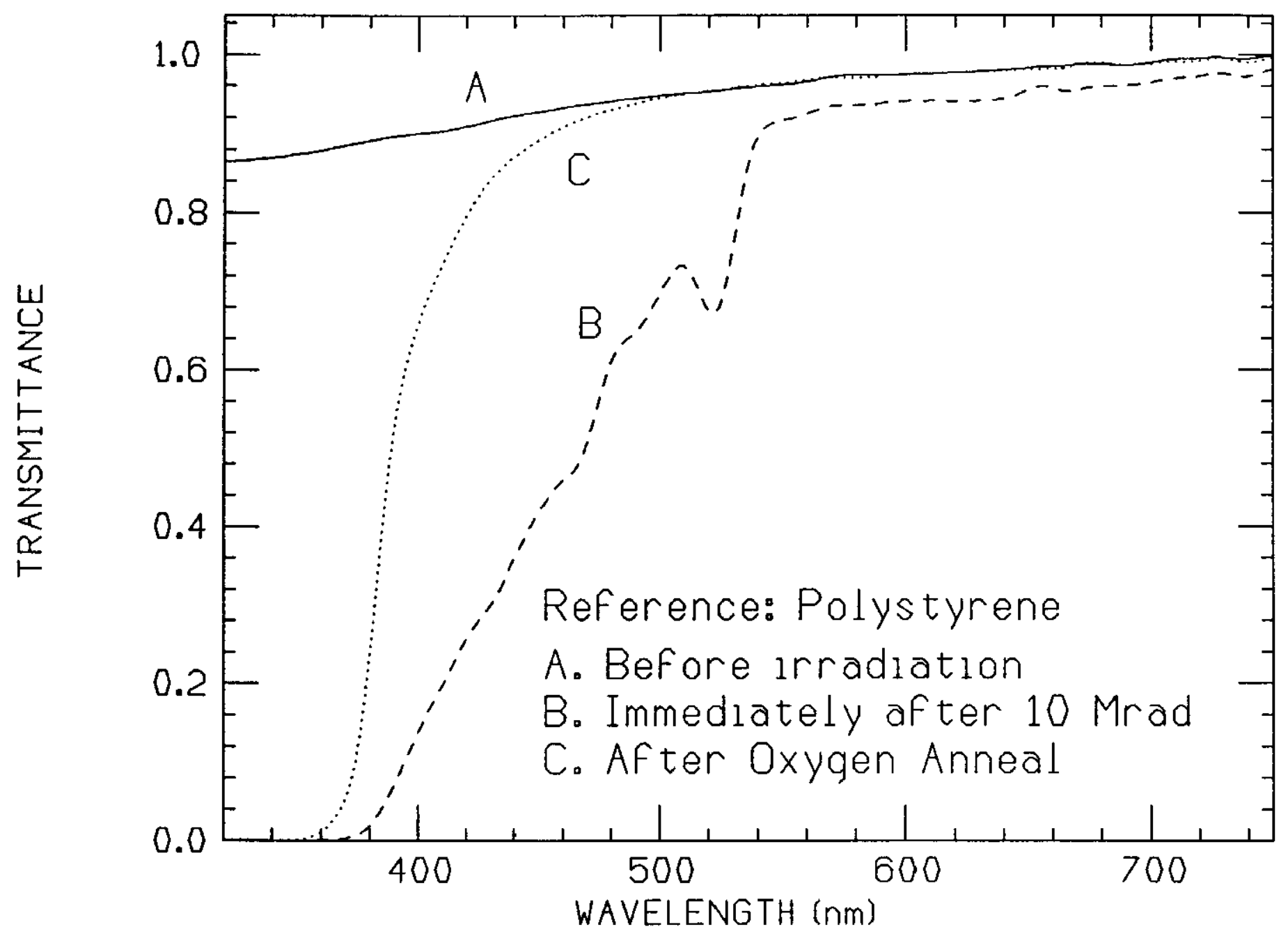




\section{APPENDIX A: LIST OF DOPANT STRUCTURES}




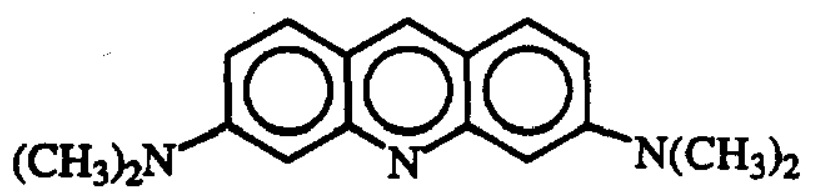

ACRIDINE O B

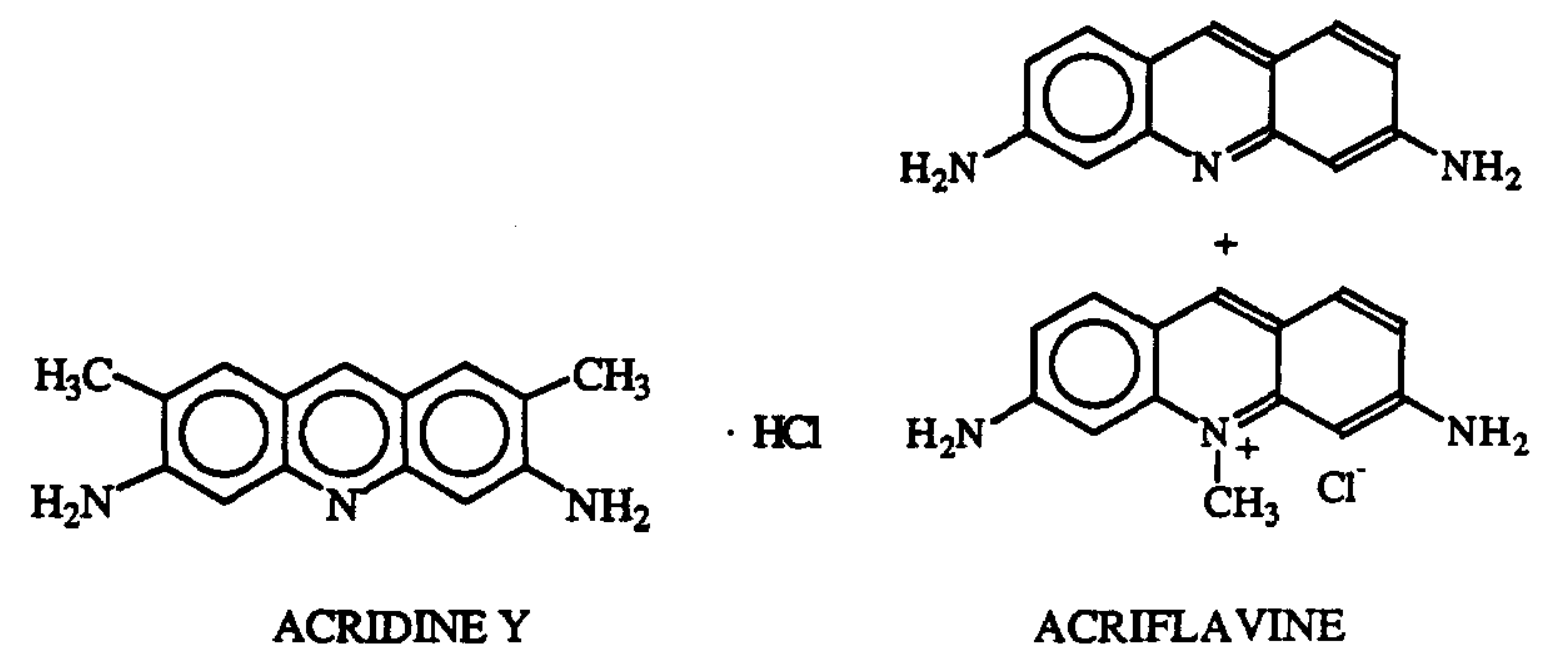

$\left(\mathrm{CH}_{3}\right)_{3} \mathrm{C}$

BBOT<smiles>CCN(CC)c1ccc(C)c(C=Cc2ccc(C#Cc3ccccc3C)cc2)c1</smiles>

bis-MSB

$\mathrm{C} 35 / \mathrm{C} 481$ 
<smiles>O=c1cc(C(F)(F)F)c2cc3c4c(c2o1)CCCN4CCC3</smiles>

C153K/C153LP<smiles>CC(C)(C)OC(=O)c1cc2cc3c4c(c2oc1=O)CCCN4CCC3</smiles>

C338<smiles>Cc1cc(=O)oc2c3c4c(cc12)CCCN4CCC3</smiles>

C480<smiles>Nc1ccc2c(C(F)(F)F)cc(=O)oc2c1</smiles>

C490<smiles>CCOC(=O)c1cc2cc3c4c(c2oc1=O)C(C)(C)CCN4CCC3(C)C</smiles>

C314T<smiles>O=c1oc2c3c4c(cc2c2c1CCC2)CCCN4CCC3</smiles>

C478<smiles>CN(C)c1ccc2c(C(F)(F)F)cc(=O)oc2c1</smiles>

C485<smiles>CS(=O)(=O)c1cc2cc3c4c(c2oc1=O)CCCN4CCC3</smiles>

C498 
<smiles>CCNc1ccc2c(C(F)(F)F)cc(=O)oc2c1</smiles>

C500<smiles>CCOC(=O)c1cc2cc3c4c(c2oc1=O)CCCN4CCC3</smiles>

C504<smiles>CCN(CC)c1ccc2cc(-c3nc4ccccc4n3C)c(=O)oc2c1</smiles>

C515<smiles>CC(=O)c1cc2cc3c4c(c2oc1=O)CCCN4CCC3</smiles>

C521<smiles>CCNc1cc2oc(=O)cc(C(F)(F)F)c2cc1C</smiles>

C503<smiles>O=c1oc2c3c4c(cc2cc1-c1cccnc1)CCCN4CCC3</smiles>

C510<smiles>O=C(O)c1cc2cc3c4c(c2oc1=O)CCCN4CCC3</smiles>

C519<smiles>CN1CCCc2cc3c(C(F)(F)F)cc(=O)oc3cc21</smiles>

C522 
<smiles>N#Cc1cc2cc3c4c(c2oc1=O)CCCN4CCC3</smiles>

C523

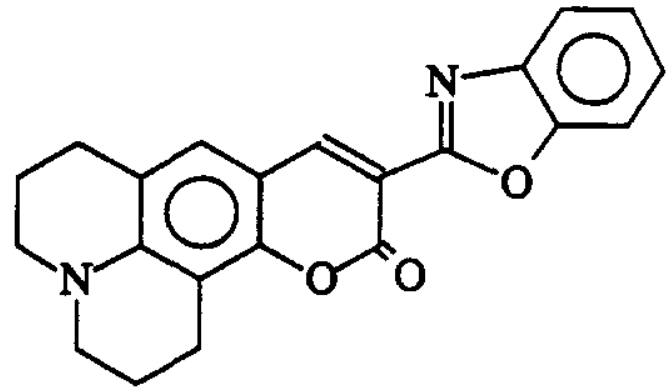

C525<smiles>CCN(CC)c1ccc2cc(-c3nc4ccccc4[nH]3)c(=O)oc2c1</smiles>

C535<smiles>CCN(CC)c1ccc2cc(-c3nc4ccccc4s3)c(=O)oc2c1</smiles>

C540<smiles>O=c1oc2c3c4c(cc2cc1-c1nc2ccccc2s1)CCCN4CCC3</smiles>

C545<smiles>Cc1cc(=O)[nH]c2cc(N(C)C)ccc12</smiles>

CARBOSTYRIL3 
<smiles>Cc1cc(=O)[nH]c2cc(N)ccc12</smiles>

CBSTY124<smiles>CC1=CC(=C(C#N)C#N)C=C(/C=C\c2ccc(N(C)C)cc2)O1</smiles>

DCM/DCM2<smiles>CC(=O)Oc1ccc2c(c1)Oc1cc(OC(C)=O)ccc1C21OC(=O)c2ccccc21</smiles>

DiACFN

DiBRFN<smiles>O=C1OC2(c3cc(Cl)c(O)cc3Oc3cc(O)c(Cl)cc32)c2ccccc21</smiles>

DiCIFN<smiles>CC[N+]1C(=CC=Cc2oc3ccccc3[n+]2CC)Oc2ccccc21</smiles>

DOCI<smiles>Cc1nc(-c2ccc(-c3nc(C)c(-c4ccccc4)o3)cc2)oc1-c1ccccc1</smiles>

DMPOPOP 
( $2-\mathrm{C}=\mathrm{C}-\mathrm{C}=\mathrm{C}$

DODCI<smiles>CCN1C(=CC#Cc2sc3ccccc3[n+]2CC)Sc2ccccc21</smiles>

DTCI<smiles>CCN1C(=CC=C=CC=Cc2sc3ccccc3[n+]2CC)Sc2ccccc21</smiles>

\section{DTDCI}<smiles>CN1C(=CC=CC=C=C2N(C)c3ccccc3C2(C)C)[N+](C)c2ccccc21</smiles>

HIDCI<smiles>O=C1OC2(c3ccc(O)cc3Oc3cc(O)ccc32)c2ccc(N=C=S)cc21</smiles> 
<smiles>CCN(CC)c1ccc2c(-c3ccc(S(=O)(=O)O)cc3S(=O)(=O)O)c3ccc(=[N+](CC)CC)cc-3oc2c1</smiles>

KTION RED<smiles>O=c1ccc2cc3c4c(c2o1)CCCN4CCC3</smiles>

LD490<smiles>CC1=CC(=C(C#N)C#N)C=C(C=Cc2cc3c4c(c2)CCCN4CCC3)O1</smiles>

\section{LD688}<smiles>CCN(CC)c1ccc(C=CC=Cc2cc[n+](CC)cc2)cc1</smiles>

LDS722<smiles>CN(C)c1ccc(C=CC=CC2=[N+](C)c3ccccc3C2(C)C)cc1</smiles>

LDS730 


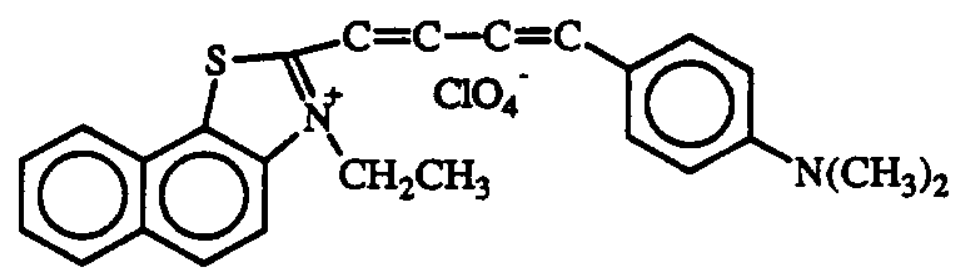

\section{LDS750}

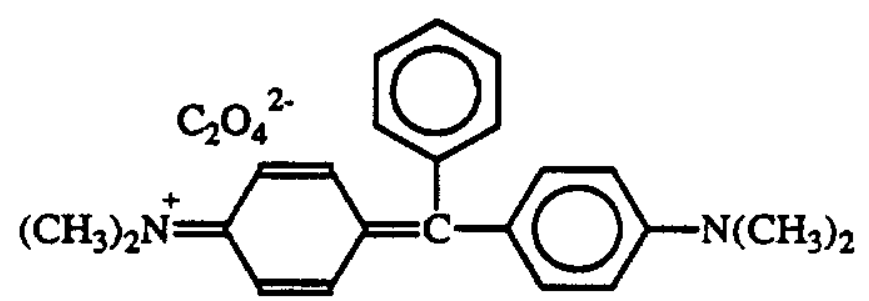

\section{MALACHITE GREEN}<smiles>CCN(CC)c1ccc2c(c1)=[O+]Oc1cc(N)c3ccccc3c1N=2</smiles>

NILE BLUE<smiles></smiles>

OXAZINE 725 


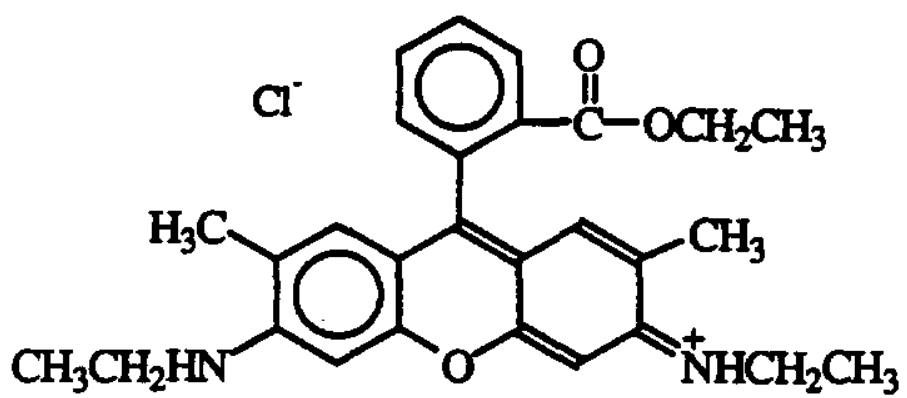

RHODAM 6G

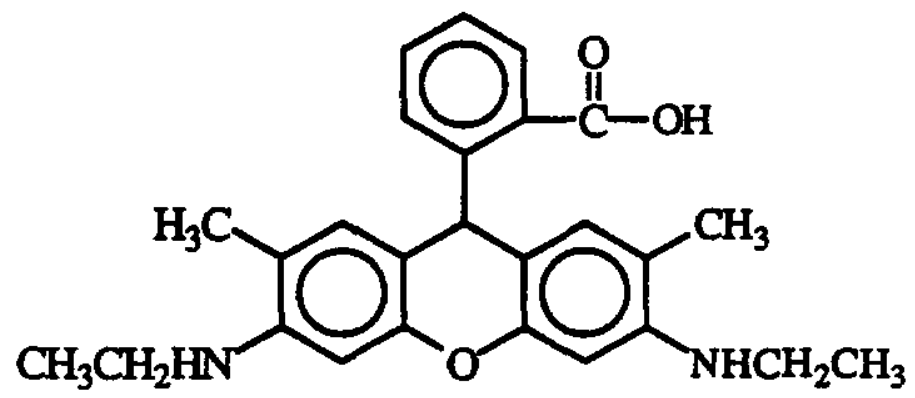

RHOD 575

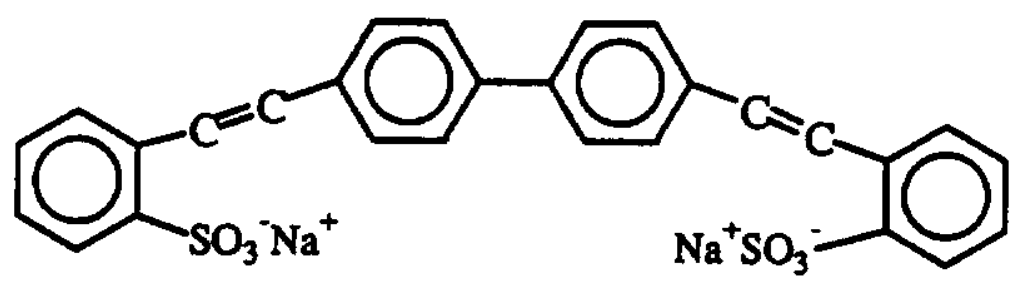

STILBENE 420 


\section{APPENDIX B: LIST OF DOPANT NAMES}




\section{DOPANTS}

\section{ACRIDINE OB ACRIDWNEY ACRIFLAVINE}

\section{BBOT}

bis-MSB

C35/C481

C153K/C153LP

C314T

C338

C478

C480

C485

C490

C498

C500

C503

C504

C510

C515

C519

C521

C522

C523

C525

C535

C540

C545

CBSTY 3

CBSTY 124

DCMDCM2

DIACFN

DIBRFN
494-38-2

135-49-9

8048-52-0

7128-64-5

13280-61-0

41934-47-8

$53518-18-6$

113869-06-0

62669-75-4

41175-45-5 41267-76-9

53518-14-2

53518-15-3

$87331-48-4$

52840-38-7

55804-70-1

55804-66-5

87349-92-6

41044-12-6

$55804-65-4$

55804-67-6

53518-19-7

55804-68-7

$87331-47-3$

27425-55-4

38215-36-0

85642-11-1

19840-99-4

$51325-91-8$

596-09-8

596-03-2 3,6-bis(dimethylamino)acridine

3,6-diamino-2,7-dimethylacridine mydrochloride

acriflavinium chbride

\section{2,5-bis-5'-tentbutyl-benzoxazolyl-(2')-thiophene}

1,4-bis(2-methylstyryi)benzene

\section{7-(diethylamino)-4-(trifluoromethyl)-2H-1-benzopyran-2-one}

2,3,6,7-tetrahydro-9-(trilluoromethy-1H,5H,11H-1 1 benzopyrano[6,7,8-ij]quinolizine-11-one 2,3,6,7-tetrahydro-1,1,7,7-tetramethyl-11-0xo-1H,5H,11H(1)benzopyrano(6,7,8i) quinolizine-10-carboxylic acid ettryl ester

1,1-dimethytethyl-2,3,6,7-tetrahydro-11-oxo- $1 \mathrm{H}, 5 \mathrm{H}, 11 \mathrm{H}$ (1)benzopyrano(6,7,8ii) quinolizine-10-carboxylate

2,3,6,7,10,11-hexahydro-1H,5H-cyclopenta[3,4 [1]benzopyran[6,7,8-ii]quinolizin-12(9H)-one 2,3,6,7-tetrahydro-9-methyl-1H, $5 \mathrm{H}, 11 \mathrm{H}-[1]$ benzopyrano[6,7,8-ij]quinolizine-11-one 7-(dimethylamino)-4-(trifluoromethyl)-2H-1-benzopyran-2-one

7-amino-4-(trifouoromethyl)-2H-1-benzopyran-2-one

2,3,6,7-tetrahydro-10-(methylsulionyl)-1H,5H,11H-11 benzopyrano(6,7,8-ij)quinolizin -11-one

7-(ethylamino)-4-(trifluoromethyl)-2H-1-benzopyran-2-one

7-(ethylamino)-6-methyt-4-(trifluoromethyt)-2H-1-benzopyran-2-one

ethyl-2,3,6,7-tetrahydro-11-oxo-1H,5H,1 HH(1)benzopyrano(6,7,8-ii)quinolizine-10-carboxylate 2,3,6,7-tetrahydro-10-(3-pyridinyl)-1H,5H, $11 \mathrm{H}-1$ 1 benzopyranol 6,7,8-ij]quinolizin-11-one 7-(dimethylamino)-3-(1-methyl-1H-benzimidazot-2-yl)-2H-1-benzopyran-2-one 2,3,6,7-letrahydro-11-oxo-1H,5H,11H-11]benzopyrano[6,7,8-4]quinolizine-10-carboxylic acid 10-acetyl-2,3,6,7-tetrahydro-1H,5H,11H-[1]benzopyrano[6,7,8-ij]quinolizin-11-one 6,7,8,9-tetrahydro-9-methyl-4-(trifluoromethyl)-2H-pyrano[3,2-g]quinolin-2-one 2,3,6,7-tetrahydro-11-oxo-1H,5H,11H-[1]benzopyrano $[6,7,8-1]$ quinolizine-10-carbonirile 10-(2-benzoxazolyl)-2,3,6,7-tetrahydro-1H,5H, $11 \mathrm{H}$-(1) benzopyrano[6,7,8-ij]quinolizin-11-one 3-(1H-benzimidazole-2-yl)-7-(diethylamino)-2H-11 benzopyran-2-one

3-(2-benzothiazolyl)-7-(diethylamino)-2H-[1]benzopyran-2-one

10-(2-benzothlazotyl)-2,3,6,7-tetrahydro-1H,5H,11H-[1] benzopyrano $6,7,8$-ij]quinolizin-11-one 7-dimethylamino-4-methylquinolone-2

7-amino-4-methyl-2(1H)-quinolinone

[2-[2-[4-(dimethylamino)phenyl]etheny)]-6-methyl-4H-pyran-4-ylidene]-propanedinitrile fhorescein diacotate

4',5'-dibromofluorescein 


\begin{tabular}{|c|c|c|}
\hline DOPANTS & CAS $*$ & NAME \\
\hline $\begin{array}{l}\text { DiCLFN/FN548 } \\
\text { DMPOPOP } \\
\text { DOCI } \\
\text { DODCI } \\
\text { DOOCI } \\
\text { DTCI } \\
\text { DTDCI }\end{array}$ & $\begin{array}{l}76-54-0 \\
3073-87-8 \\
14806-50-9 \\
514-73-88\end{array}$ & $\begin{array}{l}2^{\prime}, 7^{\prime}-\text { dichloro-3',6-dihydroxy-spirofisobenzofuran-1(3H), } 9^{\prime}-[9 H] \text { xanthen-3-one } \\
\text { 1,4-bis(4-methyl-5-phenyloxazol-2-yl)-benzene } \\
\text { diethyloxacarbocyanine lodide } \\
\text { 3-ethyl-2-(5-(3-ethyl-2(3H)-benzoxazolyidene)-1,3-pentadienyl]-benzoxazolium iodide } \\
\text { diethylthiacarbocyanine lodide } \\
\text { 3-ethyl-2-[5-(3-ethyl-2(3H)-benzthiazolyidene)-1,3-pentadienyl]-benzthiazolium iodide }\end{array}$ \\
\hline HIDC RODIDE & $36536-22-8$ & $\begin{array}{l}\text { 2-(5-(1,3-dihydro-1,3,3-trimethyl-2H-indol-2-ylidene)-1,3-pentadienyl)-1,3,3-trimethyl- } \\
\text { 3H-indolium lodide }\end{array}$ \\
\hline ISCNFN & 3326-32-7 & fhorescoin Isothiocyanate Isomer I \\
\hline KITON RED 620 & 2609-88-3 & N-f6-(diethylamino)-9-(2,4-disullophenyl)-3H-xanthen-3-ylidenef-N-ethyl-ethanaminium hydroxide \\
\hline $\begin{array}{l}\text { LD490 } \\
\text { LD688 }\end{array}$ & $\begin{array}{l}58336-35-9 \\
51325-95-2\end{array}$ & $\begin{array}{l}2,3,6,7-t e t r a m y d r o-1 H, 5 H, 11 H,[1] \text { benzopyrano }[6,7,8-i j]-q u i n o l i z-11-o n e \\
2-\text {-methyl-6-12-(2,3,6,7-tetrathydro-1H,5H-benzo(ij]quinolizin-9-yl)ethenyl]-4H-pyran-4- } \\
\text { vlidenel-propanedinitrile }\end{array}$ \\
\hline $\begin{array}{l}\text { LDS722 } \\
\text { LDS730 } \\
\text { LDS750 }\end{array}$ & $\begin{array}{l}89846-21-9 \\
76433-27-7 \\
89872-07-1\end{array}$ & 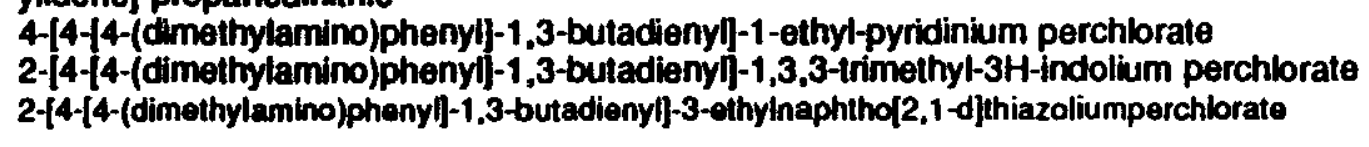 \\
\hline MALACHITE GREEN & $18015-76-4$ & $\begin{array}{l}\mathrm{N} \text {-[4-[[4-(dimethylarnino)phenyl]phenylmethylene)-2,5-cyclohexadien-1ylidene-N- } \\
\text { methytmethanaminium ethanedioate(2:2:1) }\end{array}$ \\
\hline NILE BLUE & $53340-16-2$ & 5-amino-9-(diethylamino)-benzo[a]phenoxazin-7-lum perchlorate \\
\hline OXAZINE 725 & 24796-94-9 & 3,7-bis(diethylamino)-phenoxazin-5-ium perchlorate \\
\hline PYAIDIN1 & - & • \\
\hline $\begin{array}{l}\text { RHODAMINE 6G } \\
\text { RHODAMINE575 }\end{array}$ & $\begin{array}{l}989-38-8 \\
25152-49-2\end{array}$ & $\begin{array}{l}\text { 9-(2-(ethoxycarbonyl)pheny)-3,6-bis(ethylamino)-2,7-dimethylxanthylium chloride } \\
\text { 2-[6-(ethylamino)-3-(ethylamino)-2,7-dimethyl-3H-xanthen-9-yl]-benzoic acid }\end{array}$ \\
\hline STILBENE 420 & 27344-41-8 & 2,2'-([1,1'-biphenyl]-4,4'-diyldi-2,1-ethenediyl)bis-benzenesulfonic acid disodium salt \\
\hline
\end{tabular}

